\title{
Zarys przyrodniczych i antropogenicznych uwarunkowań rozwoju systemów dolinnych i korytowych w Polsce
}

\author{
Outline of natural and anthropogenic determinants for the evolution of valley \\ and river channel systems in Poland
}

\author{
Leon Andrzejewski ๑ ', Kazimierz Krzemień ๑ 2, Zbigniew Zwoliński ๑ ${ }^{3 *}$ \\ ${ }^{1}$ Katedra Geomorfologii i Paleogeografii Czwartorzędu, Uniwersytet Mikołaja Kopernika w Toruniu \\ ${ }^{2}$ Instytut Geografii I Gospodarki Przestrzennej, Uniwersytet Jagielloński w Krakowie \\ 3Instytut Geoekologii i Geoinformacji, Uniwersytet im. Adama Mickiewicza w Poznaniu, *ZbZw@amu.edu.pl
}

\begin{abstract}
Zarys treści: Artykuł stanowi próbę przeglądu stanu aktualnej wiedzy i dyskusji dotyczącej ewolucji i typologii systemów dolinnych i korytowych na obszarze Polski. Współczesne krajobrazy systemów dolinnych oraz systemy korytowe odzwierciedlają nakładanie się wielorakich czynników zarówno naturalnych jak i antropogenicznych. Wśród nich decydujące znaczenie mają zmiany klimatyczne oraz regionalne uwarunkowania morfotektoniczne i morfogenetyczne. W ciągu ostatnich kilkudziesięciu lat krajobrazy te uległy dużym przeobrażeniom m.in. na skutek zmian klimatu i w konsekwencji zmieniających się uwarunkowań hydrologicznych, użytkowania ziemi, jak również na skutek narastającej ingerencji człowieka w systemy korytowe i dolinne. W efekcie podejmowanie są próby klasyfikacji zróżnicowanych typów i podtypów ewolucyjnych dolin rzecznych oraz odmiennych typów współczesnych układów koryt rzecznych i teras zalewowych, które odzwierciedlają złożone i często nakładające się uwarunkowania przyrodnicze i antropogeniczne.
\end{abstract}

Słowa kluczowe: system fluwialny, procesy fluwialne, typy dolin, układy koryt, zmiany klimatu, antropopresja

\begin{abstract}
The paper is an attempt to review the state of current knowledge and discussion on the evolution and typology of valley and river channel systems in Poland. Contemporary landscapes of valley systems and river channel systems reflect the overlap of multiple natural and anthropogenic factors. Among them, climate changes and regional morphotectonic and morphogenetic determinants are of crucial importance. Over the last decades, these landscapes have undergone substantial transformations, among others as a result of climate change and as a consequence of changing hydrological conditions, land use, as well as a result of increasing human interference in river channel and valley systems. It thus follows from the circumstances that attempts are made to classify different evolutionary types and subtypes of river valleys and different types of contemporary river channel patterns and floodplains that reflect complex and often overlapping natural and anthropogenic conditions.
\end{abstract}

Key words: fluvial system, fluvial processes, types of valleys, channel patterns, climate changes, anthropopressure

\section{Wstęp}

Współczesne systemy dolinne i korytowe w Polsce odzwierciedlają nakładanie się wielorakich uwarunkowań naturalnych i antropogenicznych. W zróżnicowaniu tych systemów wzdłuż profili podłużnych od obszarów górskich po wybrzeża, ważną rolę odgrywają zdarzenia, które odzwierciedlają odmienny przebieg procesów fluwialnych i miały miejsce w różnych okresach geologicznych i historycznych (Andrzejewski, Starkel 2017). Wszystkie elementy systemu fluwialnego dobrze prezentuje uniwersalny model zaproponowany przez Schumma (1977) składający się z trzech stref, tj. produkcji (dostawy, zasilania), transferu (transportu) i depozycji osadów (ryc. 1). W pierwszej z nich dostarczana jest do systemu materia $\mathrm{w}$ postaci wód powierzchniowych i podziemnych, związków rozpuszczalnych i materiału klastycznego oraz organicznego (Castelltort, Van Den Driessche 2003, $Q_{w} \mid Q_{s-i n}$ - Tofelde i in. 2019). Dynamika dostawy i dalej transportu wody i osadów jest określana jako reżim rzeczny, co ozna- 


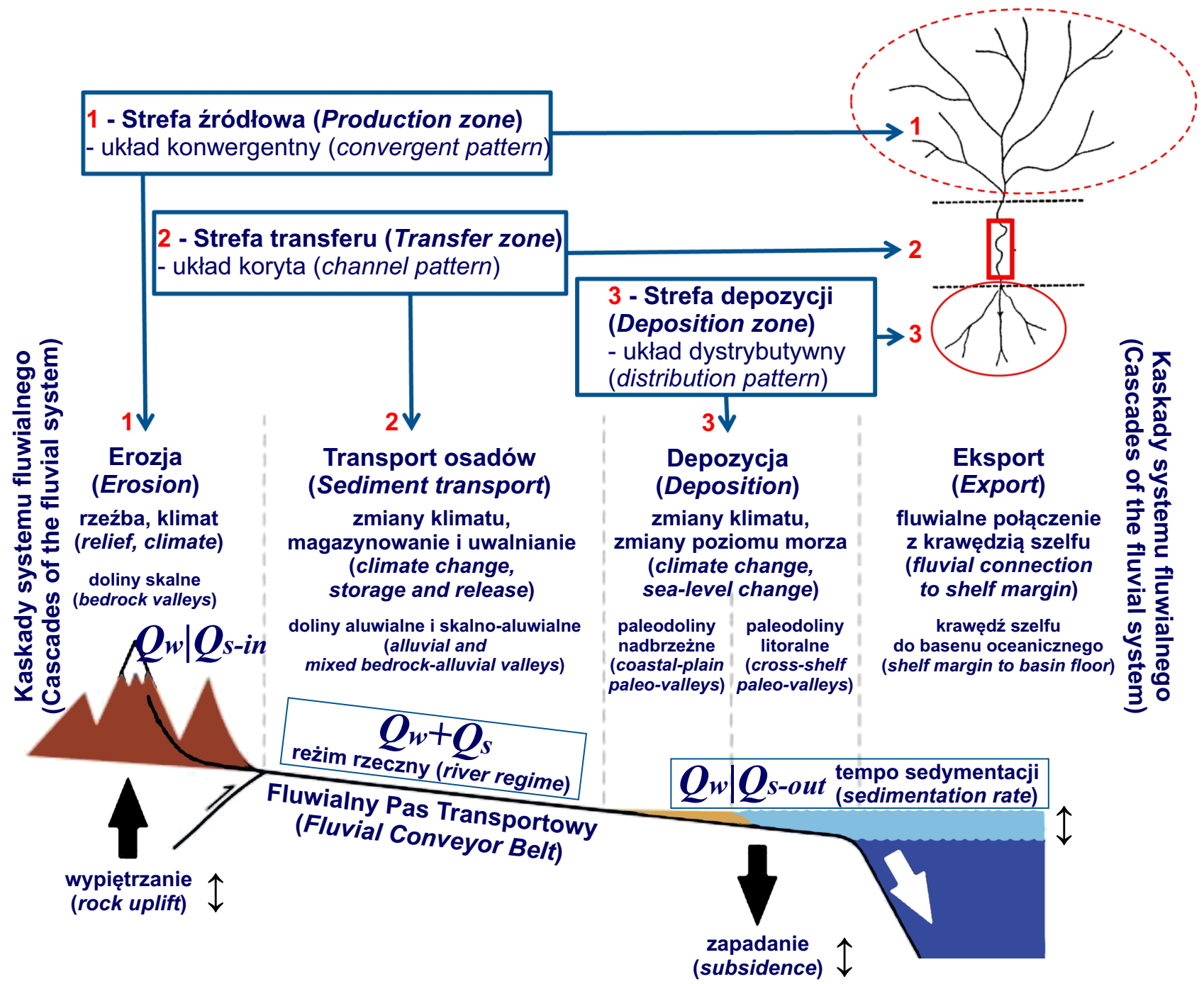

Ryc. 1. Model systemu fluwialnego w koncepcjach Schumma (1977), Zwolińskiego (1986, 1989, 2007, 2016), Castelltorta, Van Den Driessche'a (2003), Bluma, Womacka (2009) i Tofelde'a i in. (2019)

Fig. 1. Model of the fluvial system in the concepts of Schumm (1977), Zwoliński (1986, 1989, 2007, 2016), Castelltort, Van Den Driessche (2003), Blum, Womack (2009) and Tofelde et al. (2019)

cza komplementarne traktowanie reżimu hydrologicznego i sedymentacyjnego w korytach rzecznych (Zwoliński 1986, 1989, $Q_{w}+Q_{s}-$ Tofelde i in. 2019). W strefie tej zachodzą zazwyczaj intensywne procesy ewolucji i rozrostu systemu fluwialnego (Mazurek 2010). W strefie drugiej dominują funkcje transferowe (tranzytowe) w różnego typu korytach rzecznych. Aktywność, zróżnicowanie i zmienność koryt rzecznych w tej strefie jest w dużej mierze kontrolowana przez współczesną intensywność procesów hydrologicznych i stokowo-fluwialnych w strefie pierwszej a w mniejszym stopniu przez oddziedziczenie z poprzednich etapów rozwojowych, np. z kresu glacjalnego. Nie można jednak pomijać oddziaływania człowieka w skali lokalnej, zmieniającego przebieg procesów fluwialnych, np. poprzez zabudowę hydrotechniczną. Natomiast w trzeciej strefie dominującą rolę odgrywają procesy depozycji (tempo sedymentacji) materii wynoszonej $\mathrm{z}$ dwóch pierwszych stref, a de facto z całego dorzecza, tworzące stożki napływowe czy delty (Castelltort, Van Den Driessche 2003, $Q_{w} \mid Q_{\text {s-out }}$ - Tofelde i in. 2019). Każda $z$ tych stref może funkcjonować jako podsystem rzeczny w ujęciu kaskadowym, a więc jako łańcuch powiązanych subsystemów, z których każdy ma swoje indywidualne cechy i wymiar przestrzenny (por. Zwoliński 2007, 2016). Zatem obieg energii i materii w obrębie współczesnych systemów i subsystemów fluwialnych jest zindywidualizowany i reprezentatywny dla każdej ze stref morfogenetycznych obszaru Polski (w sensie Gilewska 1991), a więc $\mathrm{w}$ obszarach gór, pogórzy, wyżyn oraz nizin staroglacjalnych i młodoglacjalnych (ryc. 2). Otwartość tych systemów powoduje ich wspólne przenikanie się na różnych ich poziomach, tworząc swoistego rodzaju kontinuum procesów przepływu energii i obiegu materii. Współczesny obraz systemów dolinnych i korytowych, niezależnie od uwarunkowań 
wynikających ze złożonej przeszłości geologicznej, w znaczącym stopniu jest wyrazem zmieniających się południkowo i równoleżnikowo warunków klimatycznych (Niedźwiedź, Starkel 2008, Jania, Zwoliński 2011), decydujących o kierunkach i trendach zmian reżimów rzecznych (hydrologicznych i sedymentacyjnych). Konsekwencją takiego ujęcia funkcjonowania współczesnych systemów dolinnych jest ich niepowtarzalność międzystrefowa, uzależniona od lokalnych i regionalnych uwarunkowań przyrodniczych oraz przekształceń antropogenicznych. Ale $z$ drugiej strony ich uniwersalizm wynika $z$ nadrzędności niektórych zmiennych niezależnych takich jak: budowa geologiczna, litologia oraz strefowość i piętrowość uwarunkowań klimatycznych i ich konsekwencji, m.in. w postaci zróżnicowanej pokrywy glebowej i szaty roślinnej, warunków fizjograficznych itp.
Problematyka dotycząca systemów dolin i koryt rzecznych leży na styku geomorfologii, geologii i hydrologii, co jest przyczyną różnorodności podejść badawczych (ryc. 3). Podejścia morfostatyczne, morfodynamiczne, hydrologiczne i sedymentologiczne nawiązują odpowiednio do czterech podstawowych elementów tworzących środowisko koryta rzecznego: form, procesów, wody i osadów. Wszelkie cechy środowiska koryt, charakteryzujące powyższe cztery składniki mogą być ujmowane strukturalnie lub funkcjonalnie (Kaszowski, Krzemień 1999). Podejście fizjograficzne nawiązuje do warunków otoczenia systemu korytowego czyli do warunków środowiska geograficznego dorzecza. Zastosowanie wszystkich podejść badawczych równocześnie umożliwia realizację podejścia systemowego, które w najpełniejszy sposób charakteryzuje dowolny system korytowy lub dolinny pod względem jakościowym czy ilościo-

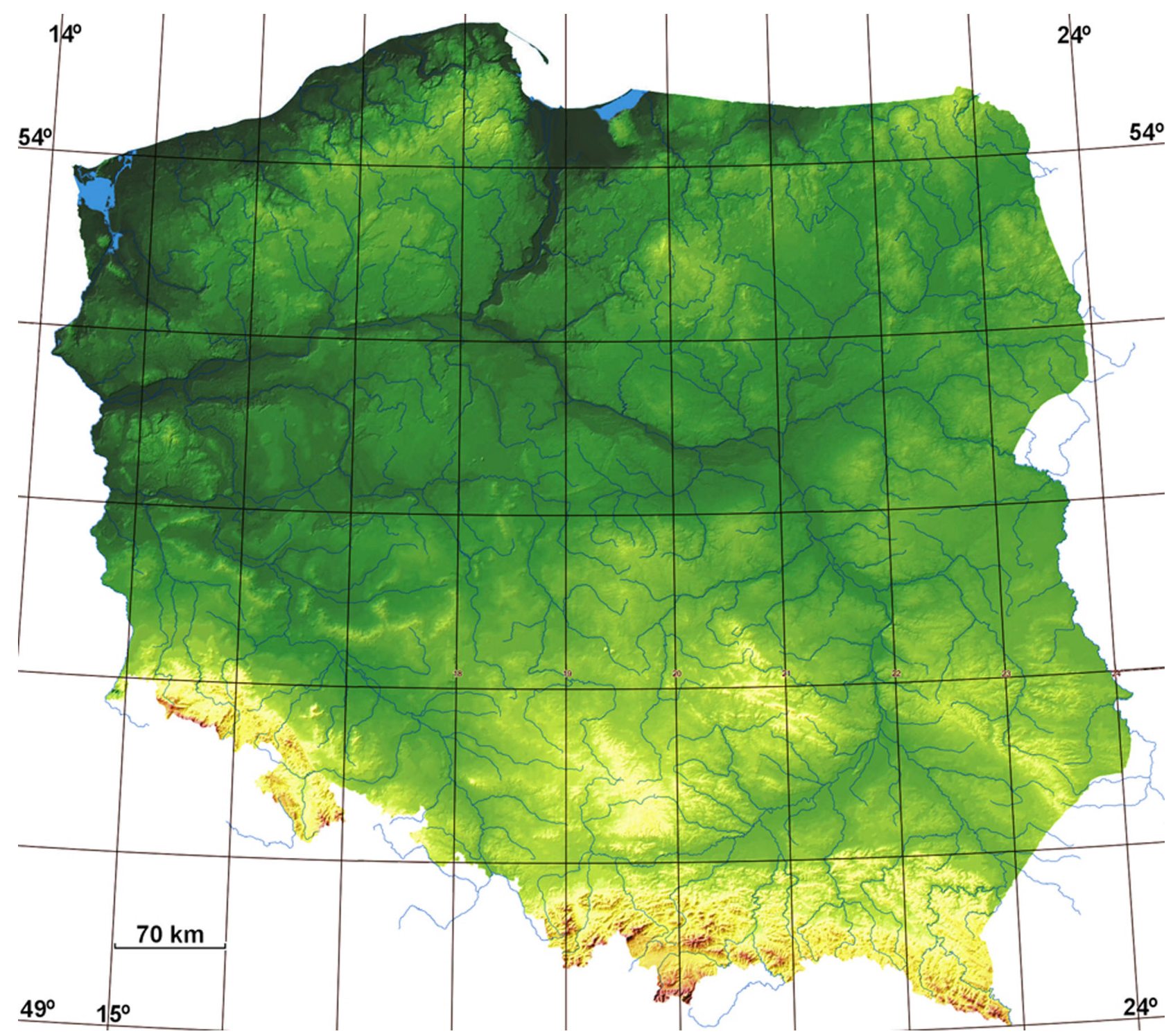

Ryc. 2. Układ sieci rzecznej w Polsce na tle cyfrowego modelu wysokościowego

Fig. 2. The pattern of the river network in Poland on the background of a digital elevation model 
wym, przestrzennym czy czasowym. W nawiązaniu do postępowań badawczych wyodrębnić można zatem pięć analogicznych podejść do klasyfikacji koryt rzecznych (ryc. 3). Geometria planarna i hydrauliczna koryt rzecznych jest wyrazem szeregu uwarunkowań przyrodniczych i antropogenicznych w całym dorzeczu. Koryta rzeczne mogą być traktowane jako syntetyczne wskaźniki dynamiki dorzecza (Froehlich 1972, 1982, Kaszowski, Krzemień 1977, Zwoliński 1989, 1998, Klimek 1991, Starkel i in. 2008, Krzemień 2012, Jokiel i in. 2017), a więc są otwartymi systemami geomorfologicznymi, które wraz z ich tendencjami rozwojowymi oraz ze względu na swoją strukturę przestrzenną i funkcjonalną można badać różnymi ujęciami metodologicznymi i metodami (Magnuszewski 2002, Kamykowska i in. 2012, Wrońska-Wałach 2012, Radecki-Pawlik 2014). O układzie koryta rzecznego, występujących w nim procesach, formach i osadach decydują zatem zarówno czynniki geologiczno-litologiczne, m.in. budowa geologiczna dna doliny, typ, struktura i dynamika obciążenia materiałem transportowanym przez rzekę, czynniki hydrologiczne takie jak: wahania stanów wody, natężenie i wielkość przepływu, jak również czynniki biotyczne: roślinność wodna, ro- ślinność nadbrzeżna czy rumosz drzewny transportowany w korycie. Współczesne przestrzenno-czasowe zróżnicowanie systemów fluwialnych jest zatem efektem długotrwałych, nakładających się procesów przyrodniczych i antropogenicznych, zachodzących w całych dorzeczach oraz w różnych ich fragmentach (Falkowski 1990, Starkel 1991a, 2001, 2008, Kostrzewski i in. 2008, Łajczak i in. 2014, Falkowski 2015, Andrzejewski, Krzemień 2017, Andrzejewski, Starkel 2017).

Celem artykułu jest ukazanie aktualnego stanu wiedzy na temat rozwoju systemów dolinnych i korytowych w Polsce, który może stać się podstawą do rozbudowania i uzupełnienia dotychczasowej typologii tych systemów. Zamierzeniem autorów jest zainspirowanie do kolejnego etapu badań nad tymi systemami w celu wypracowania ujednoliconej, uniwersalnej ich typologii uwzględniającej m.in. ich złożoność ewolucyjną oraz zróżnicowany poziom ich współczesnych przekształceń antropogenicznych. Perspektywa tych badań musi ponadto uwzględnić niejednakowy poziom aktualnej wiedzy o systemach dolinnych i korytowych w różnych regionach Polski, co powinno stymulować szereg badań uzupełniających i unifikujących.

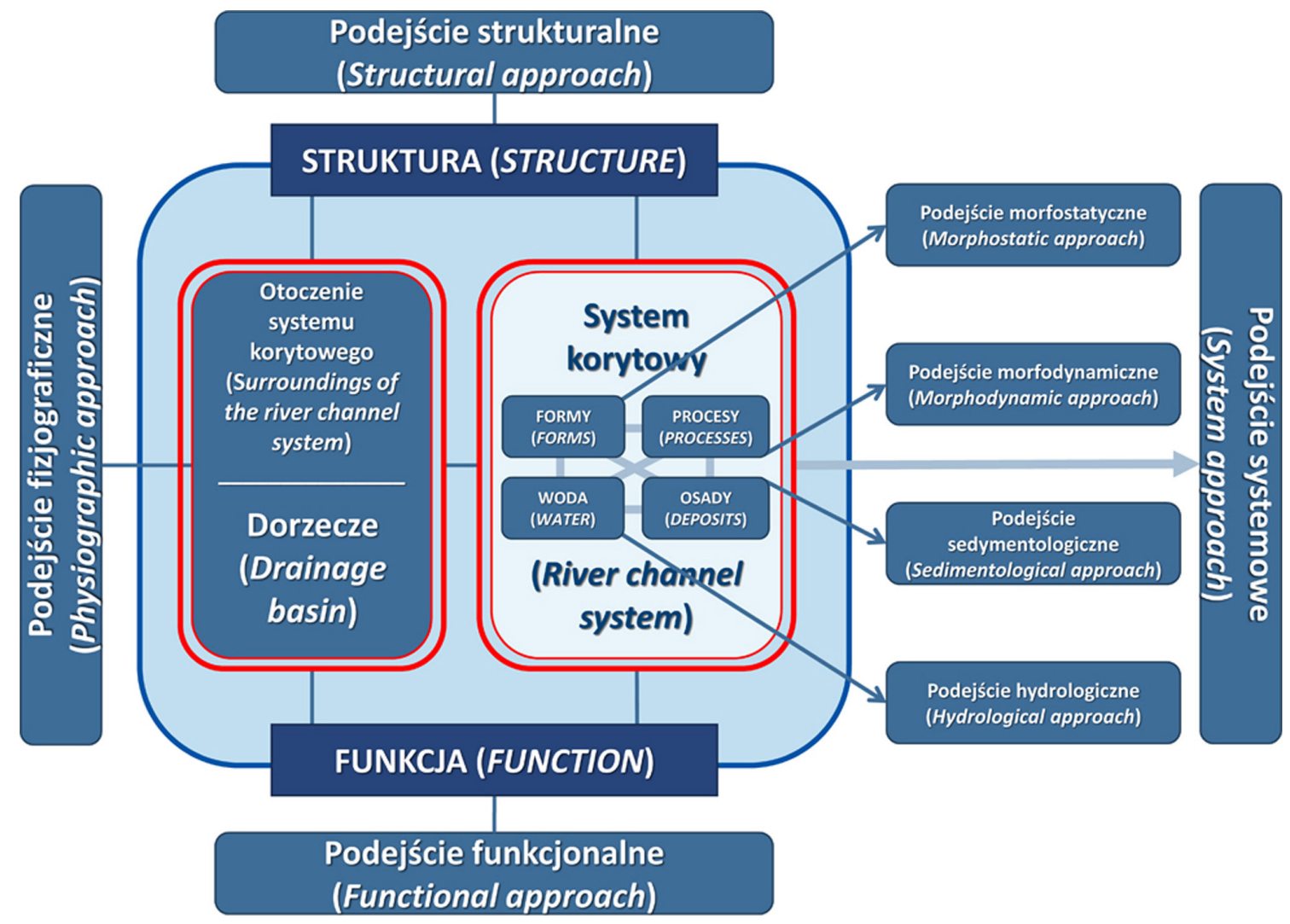

Ryc. 3. Morfostatyczne, morfodynamiczne, sedymentologiczne, hydrologiczne i systemowe ujęcia systemu fluwialnego (Kaszowski, Krzemień 1999, zmienione)

Fig. 3. Morphostatic, morphodynamic, sedimentological, hydrological and system approaches to the fluvial systems (Kaszowski, Krzemień 1999, modified) 


\section{Paleogeograficzne uwarunkowania systemów dolin rzecznych}

Rzeźba i budowa geologiczna większości dolin rzecznych na obszarze Polski wyraża zazwyczaj złożoną ewolucję, która jest wypadkową nakładających się czynników endogenicznych i egzogenicznych, w tym antropogenicznych. W każdej ze stref morfogenetycznych obszaru Polski począwszy od Karpat i Sudetów po krajobrazy młodoglacjalne na północy, relacje te ulegały istotnym zmianom, szczególnie w okresie czwartorzędowym. Wywołane zmianami klimatu epizody przyspieszonej erozji występowały kilkakrotnie w okresach kolejnych deglacjacji kontynentalnych (Starkel 1995, Vandenberghe 1995). Wieloletnie badania geologiczne, geomorfologiczne i hydrologiczne realizowane $\mathrm{w}$ obrębie dolin rzecznych pozwoliły na stosunkowo dobre rozpoznanie ich ewolucji w tym okresie (Kozarski, Rotnicki 1977, Kozarski i in. 1988, Florek 1991, 1997, Starkel 1982-1996, 1997, 2001, 2007, Starkel i in. 2007, Andrzejewski, Starkel 2017). Profile podłużne dużych dolin takich rzek jak: Wisły, Odry, Bugu, Warty, czy Narwi, przecinające różne strefy morfogenetyczne są typu poligenetycznego i polichronicznego. $Z$ biegiem tych rzek, $w$ okresie czwartorzędowym wzrastało znaczenie zmian bazy erozyjno-akumulacyjnej związanej z kolejnymi nasunięciami i wycofaniami lądolodów skandynawskich i ich lodowców wypustowych, na co później nałożyły się zmiany poziomu Morza Bałtyckiego. Równoczesne ze zmianami bazy erozyjno-akumulacyjnej, zmiany klimatyczne, wyrażające się następującymi po sobie fazami suchszymi i wilgotniejszymi zostały zapisane kolejnymi sekwencjami rozcięć erozyjnych i włożeń akumulacyjnych, wynikających ze zmiennych tendencji w przebiegu procesów fluwialnych (ryc. 4).

Ryc. 4. Typy odcinków dolin o różnej sekwencji rozcięć i włożeń (Starkel 2001)

A (A1, A2) - doliny górskie, B - doliny pogórskie, C (C1, C2, C3, C4) - doliny kotlin przedgórskich, D (D1, D2, D3) - przełomowe doliny wyżynne, E (E1, E2) - doliny wyżynne, F (F1, F2) - dolina Środkowej Wisły, G - dolina Dolnej Wisły, H - doliny dopływów Wisły w obszarze młodoglacjalnym, I - odcinki martwych pradolin; 1 - osady frakcji korytowej, 2 - osady równiny zalewowej, 3 - cokół skalny, 4 - less, 5 - torf, 6 - osady węglanowe; okresy geologiczne: V - vistulian, LV - późny vistulian, H1 - starszy holocen, H2 - środkowy holocen, H3 - młodszy holocen; strzałki oznaczają tendencję do pogłębiania, agradacji lub migracji

Fig. 4. Types of valley sections with different sequences of incisions and fills (Starkel 2001)

A (A1, A2) - mountain valleys, B - submontane valleys, C (C1, C2, C3, C4) - foreland valleys, D (D1, D2, D3) - breakthrough upland valleys, E (E1, E2) - upland valleys, F (F1, F2) - Middle Vistula valley, $\mathrm{G}$ - Lower Vistula valley, $\mathrm{H}$ - tributaries of the Vistula in the post-glacial area, I - stretches of dead marginal valleys (pradolinas); 1 - channel sediments, 2 - flood plain sediments, 3 - bedrock, 4 - loess, 5 - peat, 6 - carbonate sediments; geological periods: V - Vistulian, LV - Late Vistulian, H1 - Late Holocene, H2 - Middle Holocene, H3 - Young Holocene, arrows indicate tendencies to deepening, aggradation or migration
A1

A2

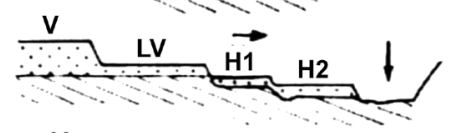

B

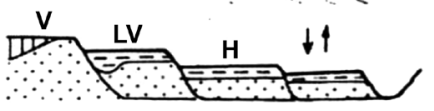

C1

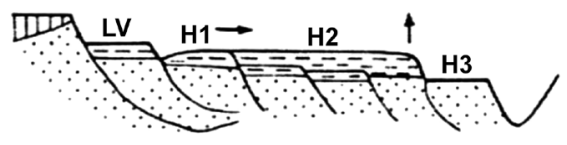

C2

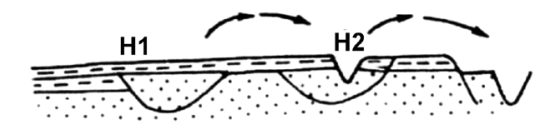

C3

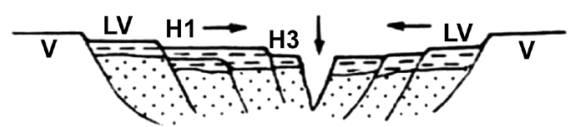

C4

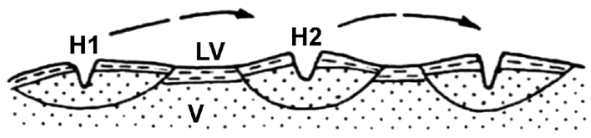

D1

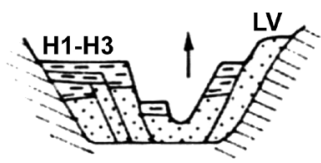

D2

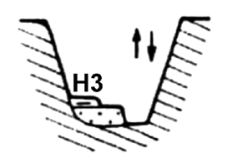

D3

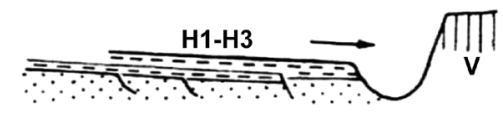

E1

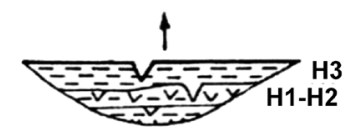

E2

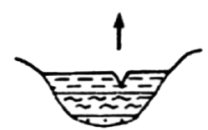

F1

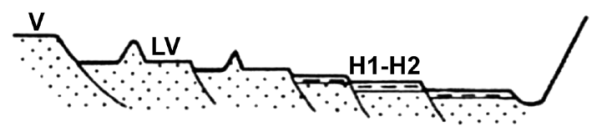

F2

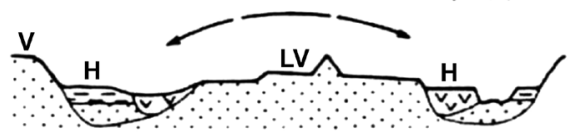

G

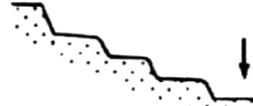

$\mathbf{H}$

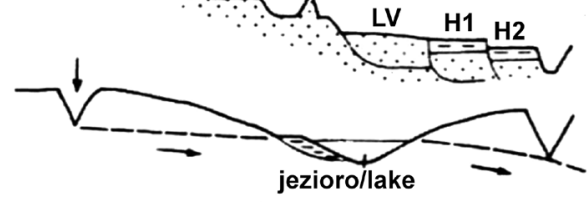

I

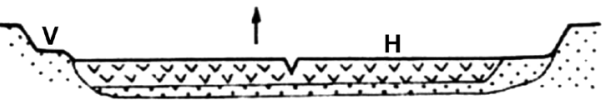


Włożenia aluwiów i odpowiadające im różnowiekowe generacje paleokoryt są szczególnie charakterystyczne na przedpolu gór, gdzie rejestrują szereg kolejnych zmian klimatycznych, polegających na następujących po sobie okresach wilgotnych i suchych. Okresy te są poznane głównie w oparciu o datowania poziomów czarnych dębów na przedpolu Karpat: 8,5-8,0 ka BP, 6,6-6,0 ka BP, 5,5-4,9, 4,5-4,1, 3,52,9 ka BP, 2,2 BC-200 AD, 425-625 AD, 1550-1850 AD (Kalicki 1991, Starkel 1991a, Kalicki, Krąpiec 1994, 1995, Starkel i in. 1996). Postępujące ocieplenie $\mathrm{w}$ późnym vistulianie i holocenie spowodowało zmianę obiegu wody i zmiany reżimu hydrologicznego rzek (m.in. Brzezińska-Wójcik, Kociuba 2001). Istotną rolę odegrała postępująca degradacja wieloletniej zmarzliny, głęboka infiltracja i wkraczanie roślinności leśnej. Zahamowane zostały w związku $z$ tym procesy spłukiwania i deflacji, co wyraziło się m.in. zmniejszeniem obciążenia rzek i zmianą struktury transportowanego ładunku (Starkel 2003). Zmniejszający się udział materiału dennego wyraził się stopniową zmianą układów koryt z roztokowych na meandrujące (Falkowski 1971, 1990, Kozarski, Rotnicki 1977, Kozarski 1983, Antczak 1986, Kozarski i in. 1988, Florek 1991, Ludwikowska-Kędzia 2000, Superson, Kociuba 2004, Kalicki 2006, Forysiak 2010, Krupa 2013, Weckwerth 2014). Proces ten uaktywniał się w ciepłych fazach późnego glacjału i na początku holocenu (Szumański 1972, 1986, Turkowska 1975, 1988, Falkowski 1975, Kozarski 1981, 1991, Starkel 1981, 1983, 2002, Kociuba, Brzezińska-Wójcik 2002, Petera 2002 i inni). Stwierdzone $\mathrm{w}$ wielu dnach dolin generacje paleomeandrów o zróżnicowanych parametrach geometrii planarnej i hydraulicznej koryt, świadczą o zmieniających się w tym czasie wielkościach przepływów (Rotnicki 1983, Antczak 1986, Gonera 1986, Rotnicki, Młynarczyk 1989, Andrzejewski 1994b, Kalicki i in. 1996, Starkel i in. 1996, Starkel 2002, Kociuba 2014, Słowik 2017, Bala 2018). Jednak przemiany z koryt roztokowych na meandrujące oraz zmiany rozmiarów paleomeandrów nie były synchroniczne na obszarze całego kraju, bowiem dokonywały się one stopniowo począwszy od młodszego dryasu, przez preboreał do subboreału (Starkel 2002). Warto podkreślić, że zmieniające się $\mathrm{w}$ okresie późnego glacjału i holocenu parametry hydrologiczne wyraziły się zmiennymi tendencjami przebiegu procesów fluwialnych, w tym tendencji do coraz intensywniejszego powodziowego rozmywania dna koryt, czego efektem jest coraz niższa lokalizacja powierzchni bazy erozyjnej oraz tendencji do zwiększania miąższości akumulacji facji korytowej i pozakorytowej, co wynika ze zmiany struktury obciążenia rzeki i wzrostu tendencji do erozji bocznej i wgłębnej przy coraz mniejszych przepływach $\mathrm{w}$ tym okresie. Zjawisko to miało miejsce nie tylko w dnach większych dolin, m.in. Prosny
(Rotnicki 1987, Rotnicki, Młynarczyk 1989), Obry (Słowik 2017), ale także mniejszych dopływów Wisły, m.in. w Wetlinie (Kukulak 2015) czy w dolnych biegach Zgłowiączki, Mieni, Tążyny i Wdy (Andrzejewski 1994a). Nie bez znaczenia było również zawężanie pasa migrowania koryt rzecznych a tym samym możliwości meandrowania rzek w swoich dnach dolinnych (Twardy 2000, 2008).

W strefie krajobrazu młodoglacjalnego prócz zmian klimatycznych obok degradacji wieloletniej zmarzliny stymulującą rolę $\mathrm{w}$ formowaniu wielkości przepływów odegrał proces intensywnego wytapiania się brył martwego lodu lodowcowego, które zalegały w licznych zagłębieniach terenowych i głębokich rynnach subglacjalnych (Piasecki 1982, Zwoliński i in. 2008). Większość z nich wytopiła się $\mathrm{w}$ okresie allerödu, ale proces ten $\mathrm{w}$ niektórych obniżeniach mógł zakończyć się dopiero w okresie preborealnym (Niewiarowski 1986, Nowaczyk 1994, Błaszkiewicz 1998, 2005). Rynny subglacjalne, niektóre fragmenty rynien glacjalnych a także zagłębienia wytopiskowe podlegały stopniowej transformacji fluwialnej i włączaniu w systemy dolinne obszarów młodoglacjalnych (Niewiarowski 1986, Andrzejewski 1994a, Mazurek 1998, Błaszkiewicz 2005). Te formy polodowcowe poprzez włączanie do systemu dolinnego nabierały z biegiem czasu typowych cech fluwialnych. Proces ten trwa w wielu fragmentach niewielkich dolin do chwili obecnej (Drwal 1985, Bajkiewicz-Grabowska 2002). Zjawisko to dobrze ilustrują niektóre fragmenty młodych dolin rzek, m.in.: Wierzycy, Wdy, Słupi, Parsęty i innych dolin Przymorza lub mniejszych dopływów Wisły takich jak: Zgłowiączki, Mieni, Raduni czy dopływu Drwęcy, rzeki Wel (Rachocki 1974, Koutaniemi, Rachocki 1981, Zwoliński 1989, Florek 1991, 1997, Andrzejewski 1994a, Błaszkiewicz 1998, 2005, Jaworski 2005). W niektórych z nich jedynie dolne odcinki rozcinające np. terasy Wisły mają w pełni cechy fluwialne, które zacierają ślady morfologii i osadów polodowcowych.

Inne doliny rozwinięte na szlakach odpływów sandrowych m.in. Skrwy, Wkry, Drwęcy, Brdy, Wdy, Gwdy charakteryzują się bogatym zestawem erozyjnych poziomów terasowych będących efektem zmian klimatycznych i obniżającej się bazy erozyjno-akumulacyjnej wynikającej z recesji ostatniego lądolodu i niskiego poziomu Bałtyku w schyłkowym okresie późnego glacjału i na początku holocenu (Galon 1953, 1968, Niewiarowski 1968, 1987, Szafraniec 2010). Od schyłku górnego plenivistulianu przez cały późny vistulian trwała więc w systemie dolin dolnej Wisły i Odry wzmożona erozja. Można przyjąć, że proces ten najintensywniej przebiegał $\mathrm{w}$ pierwszej części późnego glacjału. W tym czasie obejmującym ok. 2500 lat dolne odcinki wspomnianych dolin i ich głównych dopływów zostały pogłębione o ok. 40-50 
m (Starkel 2014). Ich dna w postaci teras nadzalewowych i równin zalewowych w głównych zarysach ukształtowane były już w schyłkowym okresie późnego glacjału. W procesie tym należy także uwzględnić rolę glacitektoniki, modyfikującej głównie zbocza dolinne (Krygowski 1962, 1974, Galon 1968, Mojski, Starkel 1990).

Podobnie w środkowych biegach głównych dolin rzecznych cykle klimatyczne wyraziły się obecnością kilku poziomów aluwialnych i generacji paleokoryt o zróżnicowanych parametrach geomometrycznych. $\mathrm{W}$ efekcie $\mathrm{w}$ różnych regionach i tym samym $\mathrm{w}$ róż- nych odcinkach profilu podłużnego dolin zapisane są ich odmienne typy ewolucyjne (Falkowski 1975, 1990, Kozarski, Rotnicki 1977, Alexandrowicz i in. 1981, Florek 1982, 1991, 1997, Starkel 1982-1996, 1988, 1991a, 1991b, 2001, Kozarski 1983, Antczak 1986, Gonera 1986, Kozarski i in. 1988, Wyżga 1993, Andrzejewski 1994a, b, Gębica 1995, Kociuba, Brzezińska-Wójcik 1999, Kociuba, Superson 2004, Forysiak 2005, Kalicki 2006, Dobrowolski i in. 2010, Gębica 2013, Krupa 2013, Michno 2013, Twardy 2013, Kociuba 2014, Falkowski 2015, Krzyszkowski i in. 2018 i inni).
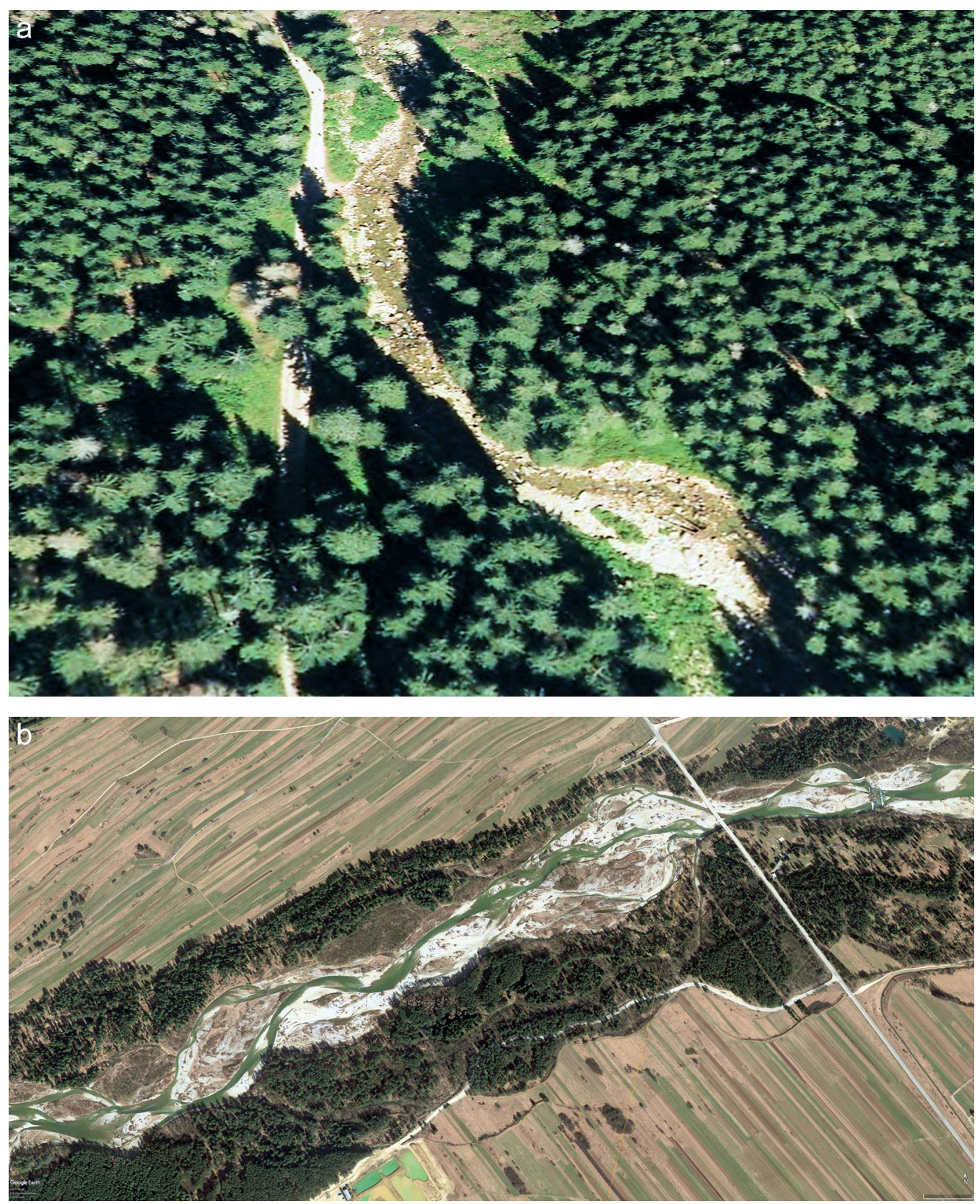

Ryc. 5. Doliny obszarów górskich (Google Maps 2018)

a) Suchy Potok Gąsienicowy w Tatrach, b) Białka powyżej Zbiornika Czorsztyńskiego

Fig. 5. Valleys of mountain areas (Google Maps 2018)

a) Suchy Gąsienicowy Stream in Tatra Mts., b) Białka River above Czorsztyn Reservoir 


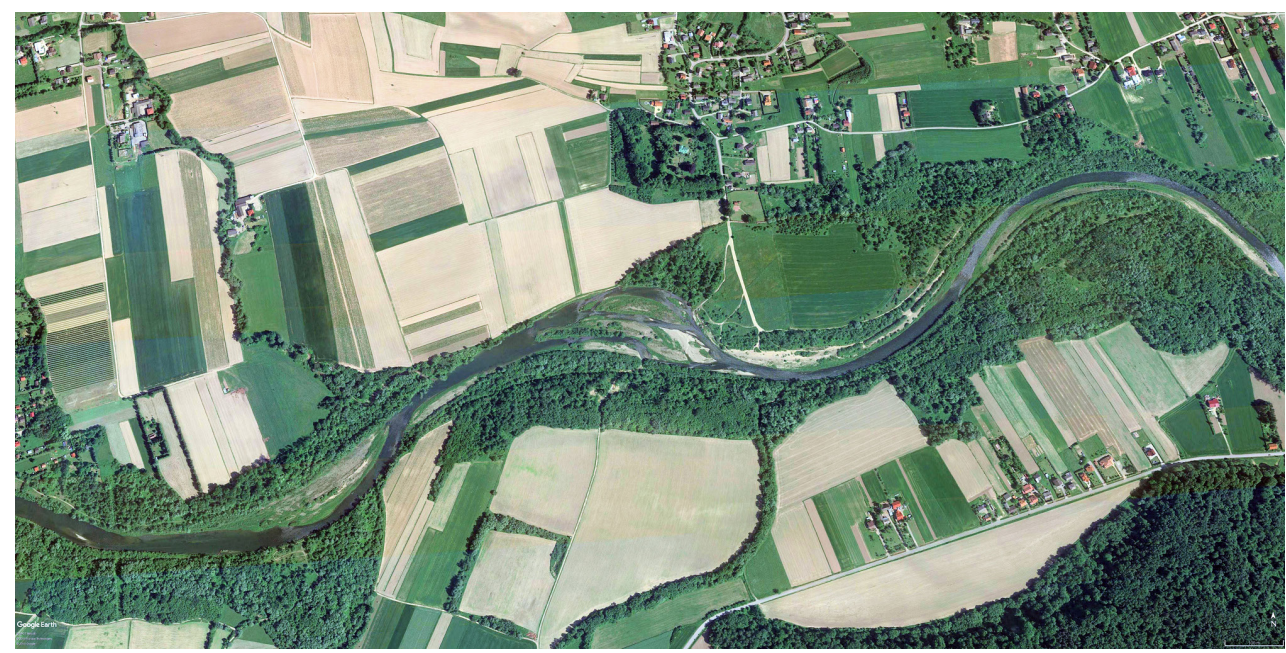

Ryc. 6. Pogórskie doliny karpackie - Raba poniżej Myślenic (Google Maps 2018)

Fig. 6. Carpathian piedmont valleys - Raba River below Myślenice (Google Maps 2018)

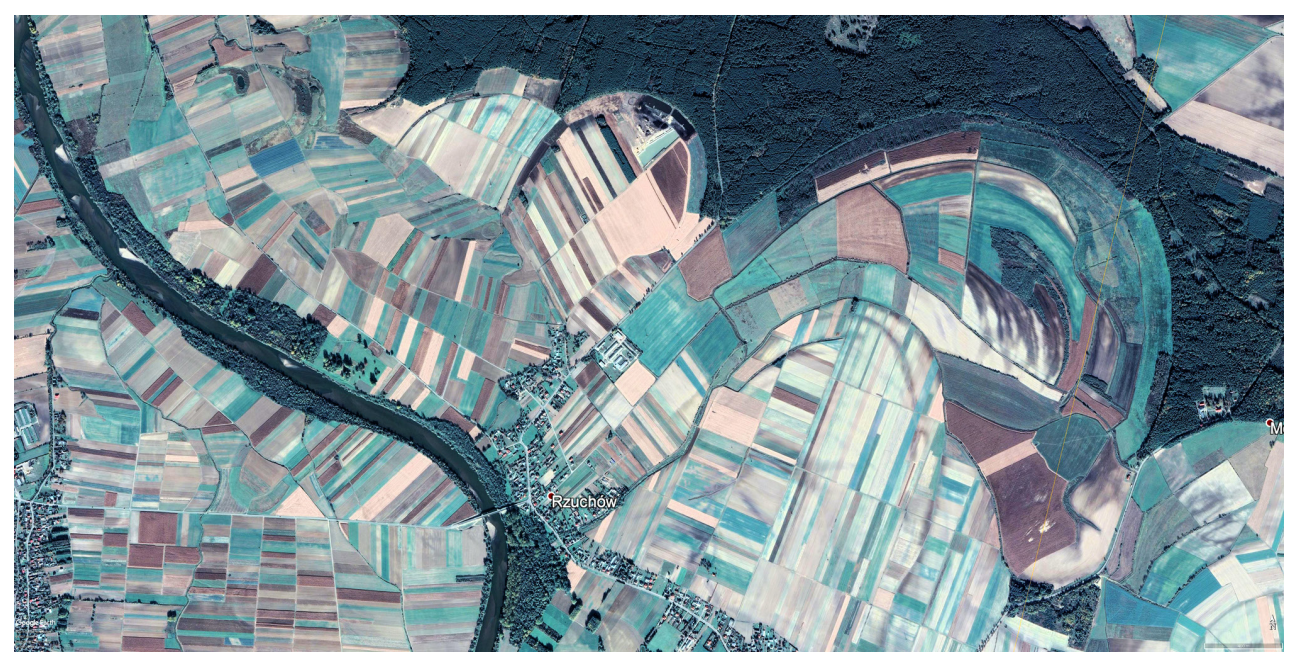

Ryc. 7. Doliny w kotlinach podkarpackich - San powyżej Leżajska (Google Maps 2018)

Fig. 7. Valleys in the Subcarpathian basins - San River above Leżajsk (Google Maps 2018)

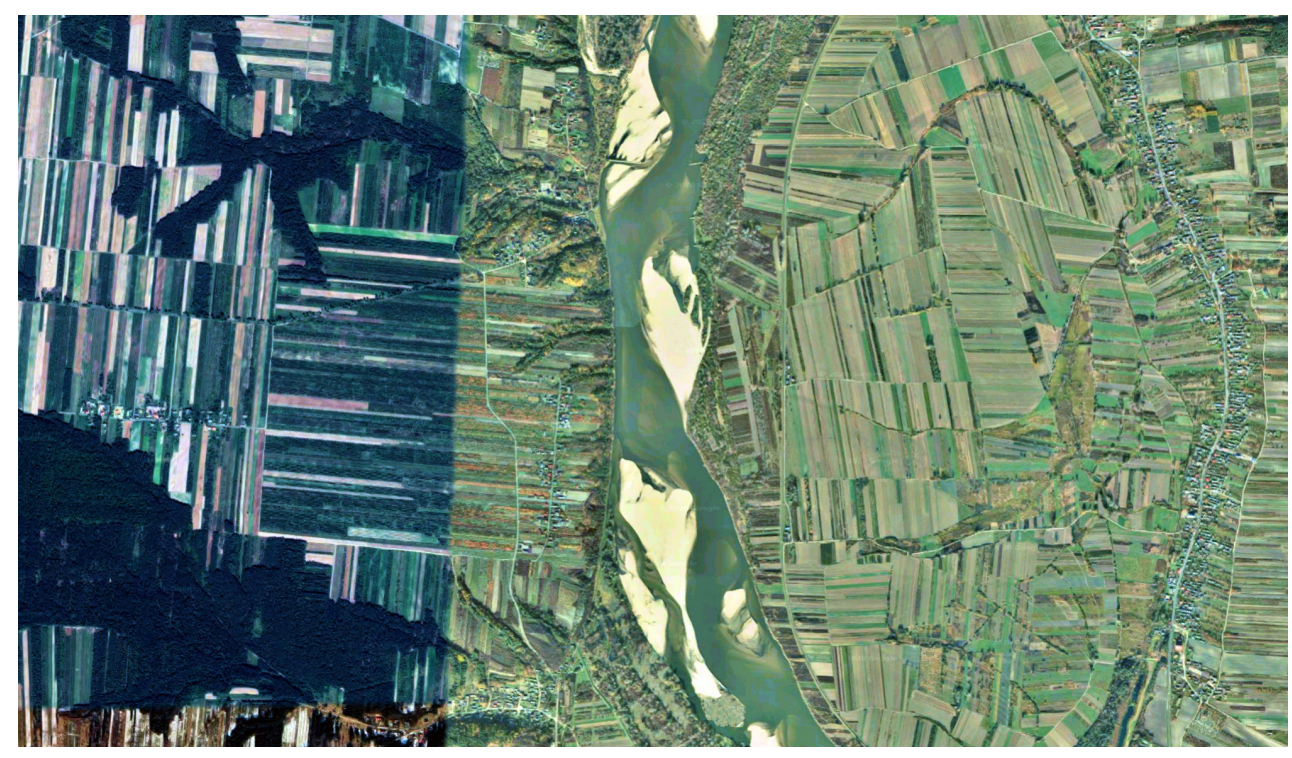

Ryc. 8. Doliny w zwężeniach przełomowych pasa wyżyn - Wisła poniżej Annopola (Google Maps 2018)

Fig. 8. Valleys in narrow river breakthrough of uplands - Vistula River below Annopol (Google Maps 2018) 


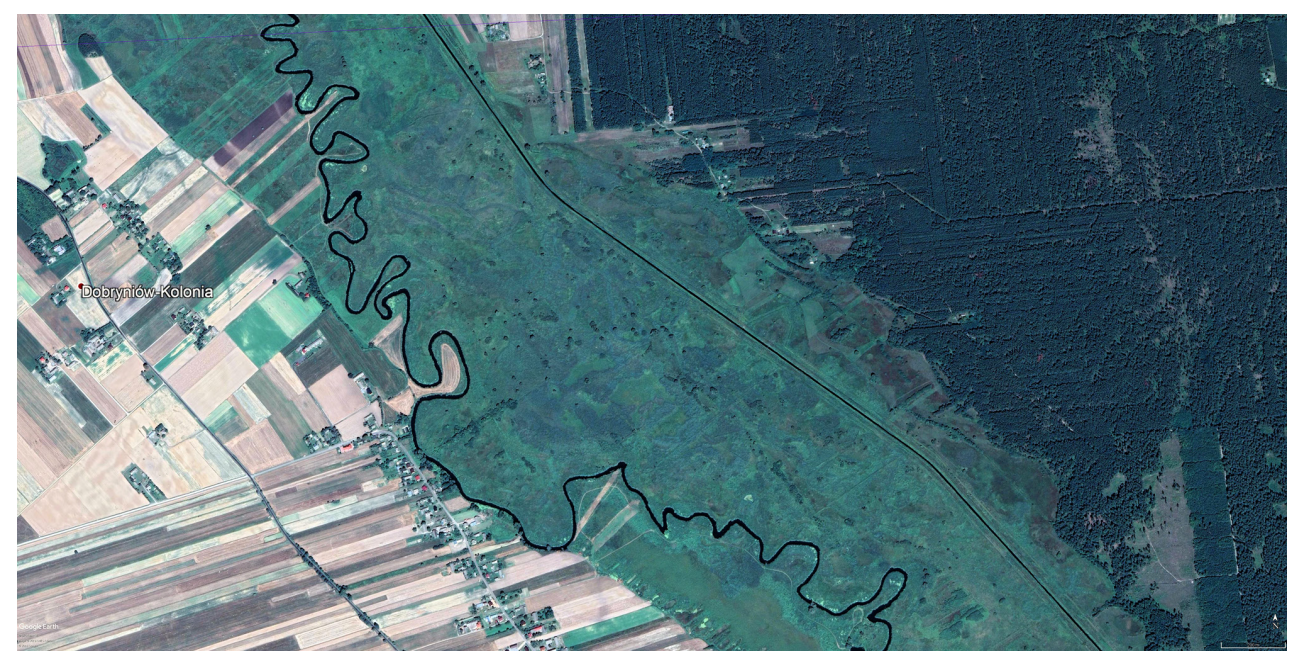

Ryc. 9. Doliny pasa wyżyn - Wieprz koło Dobryniowa (Google Maps 2018)

Fig. 9. Upland valleys - Wieprz River near Dobryniów (Google Maps 2018)

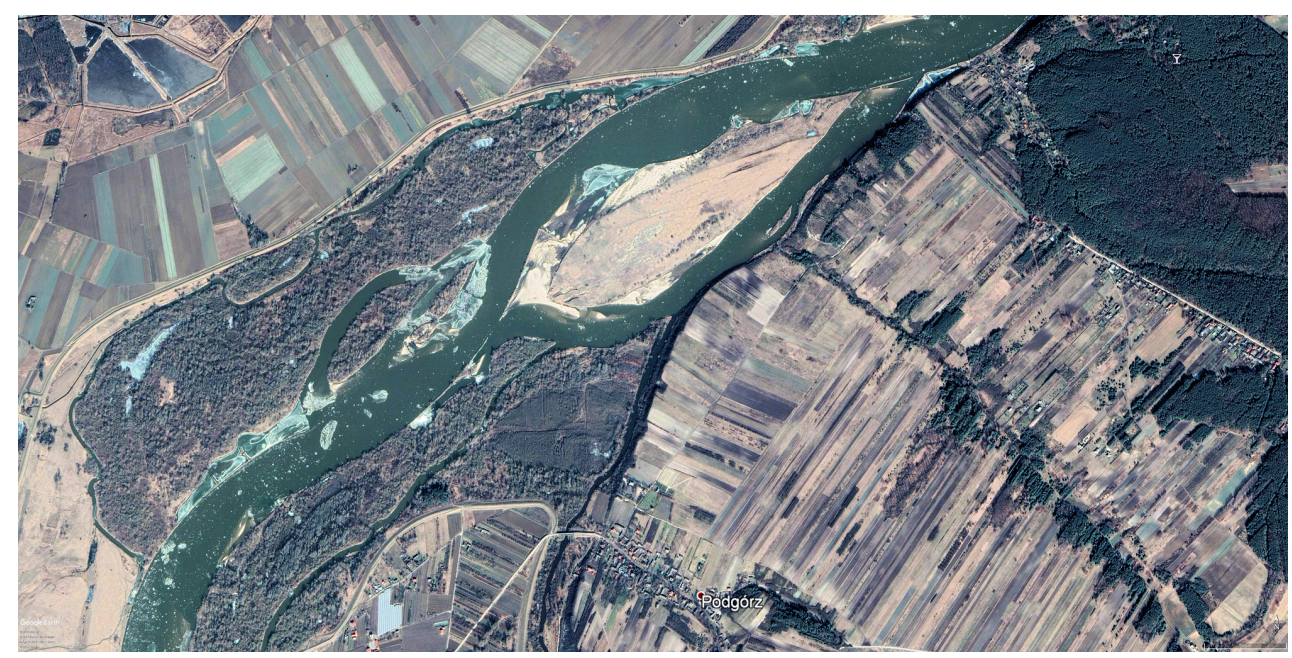

Ryc. 10. Dolina środkowej Wisły i doliny dolnych biegów jej dopływów - Wisła powyżej Kazimierza Dolnego (Google Maps 2018)

Fig. 10. The valley of the middle Vistula River and the valley of the lower course of its tributaries - the Vistula River above Kazimierz Dolny (Google Maps 2018)

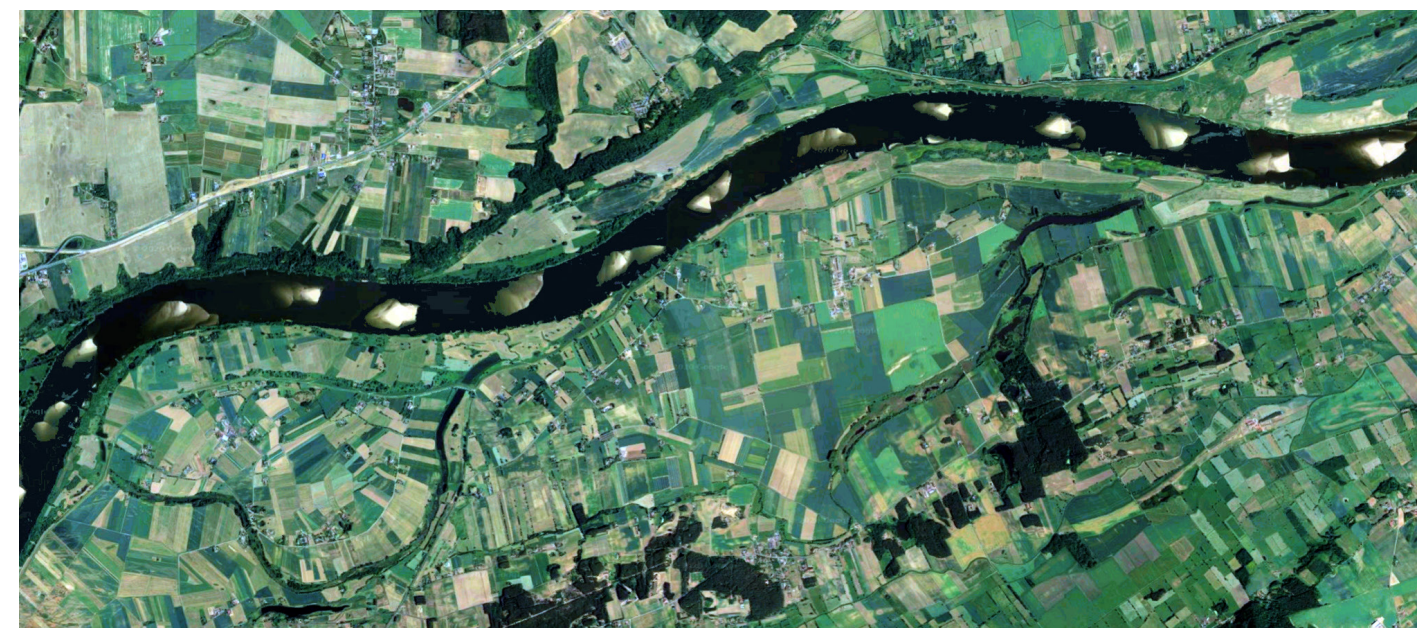

Ryc. 11. Dolina dolnej Wisły z poziomami teras erozyjnych - Wisła poniżej Świecia (Google Maps 2018)

Fig. 11. The valley of the lower Vistula River with levels of erosional terraces - Vistula River below Świecie (Google Maps 2018) 
Specyficznym elementem układów dolinnych niżu są odziedziczone $z$ plejstocenu równoleżnikowe odcinki szerokich pradolin o nierozciętych i nieodmłodzonych dnach, które w wielu fragmentach wykazują stałą tendencję do agradacji biogenicznej (Żurek 1975, Florek 1991, Andrzejewski 1994a, Żurek, Pazdur 1999, Kordowski i in. 2014). Postępującą stopniową recesję lądolodu wyrażają fragmenty przełomowych odcinków rzek na Niżu o układach zbliżonych do południkowego takich rzek jak: Wisły, Odry, Warty (Kozarski 1965, Galon 1968, Babiński 1992). Pośród odziedziczonych systemów pradolinnych wyróżnia się anastomozujący odcinek Narwi, który przy niedoborze rumowiska wleczonego i zawieszonego podlega $\mathrm{w}$ ostatnich tysiącleciach nadbudowywaniu przez sedymentację biogeniczną (Gradziński i in. 2000, 2003, Banaszuk i in. 2016). Ślady holoceń- skiego formowania się dolin rzecznych można także odczytać z osadów w kopalnych dolinach rzek Przymorza rozwiniętych współcześnie w strefie litoralnej Bałtyku (Florek i in. 2010).

Formy i osady rzeczne występujące $\mathrm{w}$ dnach dolin rejestrują zdarzenia o często odmiennym przebiegu procesów fluwialnych, które miały miejsce w różnych okresach plejstocenu i holocenu. W obrębie dorzecza Wisły wyróżniono 9 głównych typów i kilka podtypów ewolucyjnych dolin (Starkel 2001, ryc. 4):

1. doliny obszarów górskich (ryc. 5) o dużym udziale transportu rumowiska dennego i przewadze erozji nad akumulacją;

2. odcinki pogórskie dolin karpackich (ryc. 6), w których charakterystyczna jest obecność od dwóch do trzech włożeń w pokrywę z okresu vistuliańskiego; głębokie rozcięcie miało miejsce

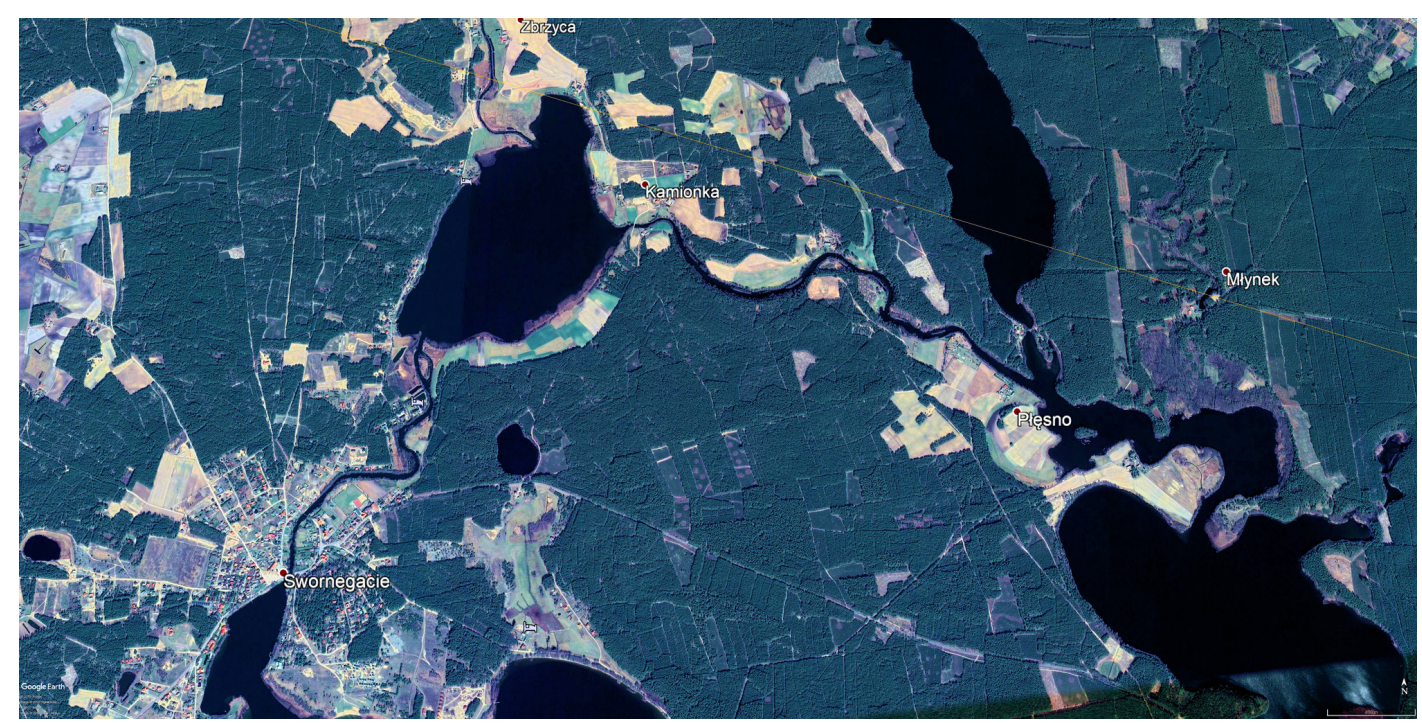

Ryc. 12. Doliny dopływów Wisły na obszarze młodoglacjalnym - Brda koło Swornegaci (Google Maps 2018)

Fig. 12. Tributary valleys of the Vistula River in the postglacial area - Brda River near Swornegacie (Google Maps 2018)

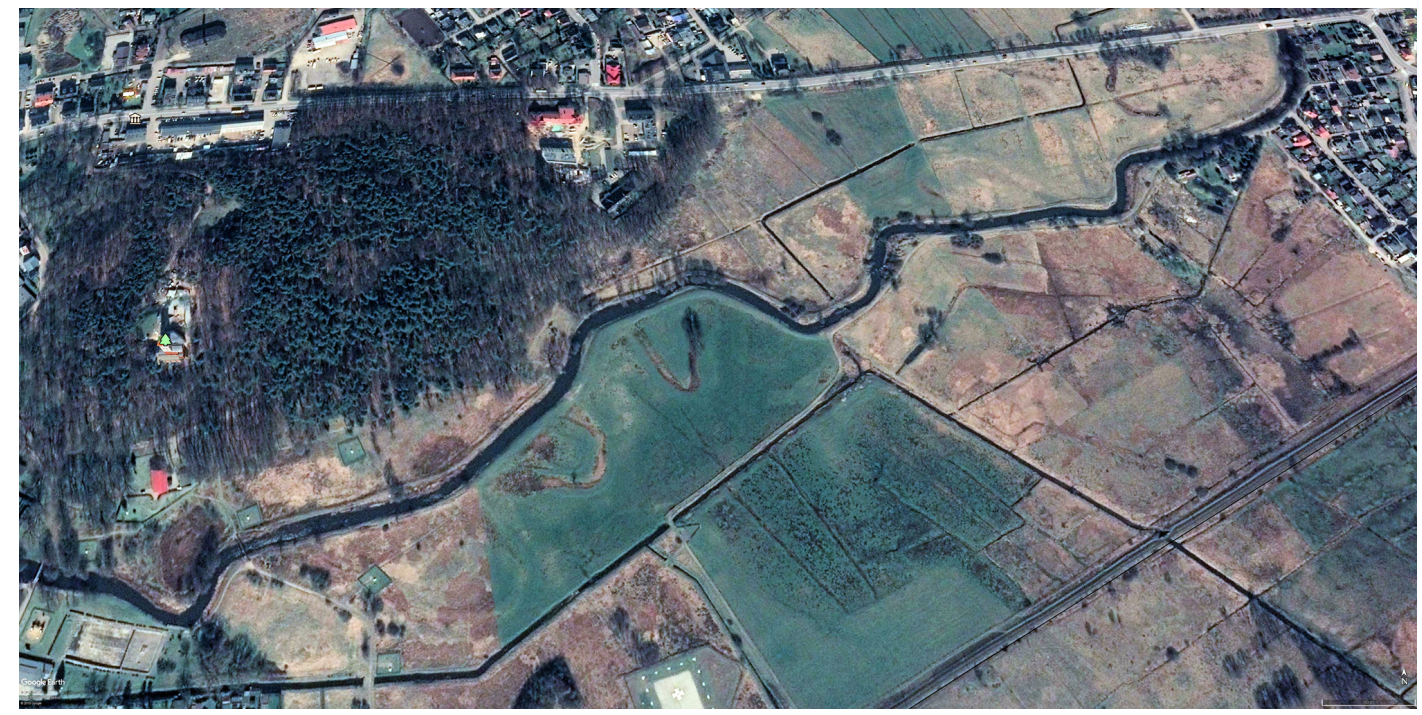

Ryc. 13. Odcinki martwych pradolin - Łeba powyżej Lęborka (Google Maps 2018)

Fig. 13. Sections of dead pradolinas - Łeba River above Lębork (Google Maps 2018) 
w późnym glacjale, a nadbudowa madami wiąże się $z$ wylesieniem;

3. odcinki dolin w kotlinach podkarpackich (ryc. 7), wykazują największą różnorodność, zależną od szerokości dna, spadku i położenia w profilu podłużnym całej doliny;

4. odcinki zwężeń przełomowych (ryc. 8), w pasie wyżyn i kotlin podkarpackich;

5. doliny pasa wyżyn (ryc. 9), o płytkich korytach, które przy braku długotrwałych wezbrań mają płaskie dna nadbudowane pozakorytowymi osadami mineralnymi i organicznymi, pochodzącymi z erozji wgłębnej i bocznej koryt;

6. dolina środkowej Wisły na niżu (głównie obszar staroglacjalny, ryc. 10) i doliny dolnych biegów jej dopływów; cechuje się występowaniem szeregu włożeń $z$ tendencją do pogłębiania koryta i zawężenia aktywnej równiny zalewowej; równoległe ciągi obniżeń wykorzystywane są w czasie wielkich wezbrań zatorowych;

7. dolina dolnej Wisły z poziomami teras erozyjnych (ryc. 11), pogłębiana intensywnie $\mathrm{w}$ czasie recesji ostatniego lądolodu aż po początek holocenu;

8. doliny dopływów Wisły na obszarze młodoglacjalnym, złożone $z$ odcinków o różnej genezie, spadku i tendencjach erozyjnych lub akumulacyjnych, ale włączane $\mathrm{w}$ jeden system, niekiedy $\mathrm{z}$ jeziorami przepływowymi (ryc. 12);

9. odcinki martwych pradolin, częściej zawieszone na poziomie wyższych teras, zwykle zabagnione lub zatorfione (ryc. 13).

Z uwagi na złożoność systemu dolinnego Wisły oraz jego tranzytowego charakteru zaproponowany model można uznać za uniwersalny dla obszaru Polski (Starkel 1997). Warto jednak przy tym zwrócić uwagę, że systemy dolinne, szczególnie dużych rzek, bardzo trudno poddają się regionalizacji fizycznogeograficznej i bardzo często pojedyncze doliny w profilu podłużnym występują równocześnie $\mathrm{w}$ wielu regionach (Grabowski i in. 2018), ale także i w wielu typach krajobrazów, dla których trudno jest jednoznacznie opisać ustrój hydrologiczny rzek (Nowicka 2009).

Specyficznym typem ewolucyjnym charakteryzują się dna dolin rzek tranzytowych, spływające $z$ obszarów górskich przez wyżynne i nizinne do obszarów nadmorskich (Ciszewski, Dubicki 2008, Łajczak i in. 2006, 2008). W obrębie dużych dolin z wyraźnym wykształceniem różnorodności facjalnej aluwiów (Zieliński 1998, 2014), funkcjonują doliny rzek tranzytowych o reżimie hydrologicznym ukształtowanym $\mathrm{w}$ obszarze górskim lub wyżynnym np. doliny Wisły i Odry, w mniejszym stopniu Warty czy Bugu. $\mathrm{W}$ ich górnych i dolnych biegach $\mathrm{w}$ dnach dolinnych czytelne są rozcięcia i włożenia rejestrujące fazy wilgotniejsze i suchsze i odpowiadające im paleokoryta. Niektóre ich fragmenty nadbudowane są aluwia- mi powodziowymi o znacznej miąższości do 3-5 m (Czajka 2007). Z kolei w rozszerzeniach dolinnych np. w Kotlinie Oświęcimskiej, Kotlinie Płockiej, Toruńskiej czy w Basenie Unisławskim doliny porozcinane są głębokimi stosunkowo wąskimi korytami o układach zbliżonych do rzek anastomozujących (Florek i in. 1987, Tomczak 1987, Niewiarowski 1987, Wiśniewski 1976, 1987). W obrębie grupy dolin kształtowanych głównie przez nizinny reżim hydrologiczny występują takie doliny jak: niżowy odcinek Wisły, Warty, Prosny, Bugu i Narwi, a także dolne biegi Bzury i Pilicy. Datowania rozcięć i włożeń w dolinie wskazują na ich synchroniczność z przedpolem obszarów górskich południa Polski (Falkowski 1975, Florek i in. 1987, Turkowska 1988, 2006, Rotnicki, Młynarczyk 1989, Andrzejewski 1991, Kozarski 1991, Twardy 2008, Forysiak 2010).

$\mathrm{Na}$ te naturalne zmiany $\mathrm{w}$ dolinach rzecznych nakładają się nie zawsze pozytywne przemiany regulacyjne spowodowane działalnością człowieka (np. Babiński 2002, Czaja i in. 1993, Kociuba 2006a, Malik, Owczarek 2006, Korpak i in. 2008, Krupa 2013, Gorczyca 2016, Fajer 2018b). Współcześnie, w ostatnich kilkunastu, kilkudziesięciu latach, wiele $z$ uregulowanych odcinków rzek podlega renaturyzacji tak naturalnej jak i sterowanej przez człowieka (Żelazo, Popek 2002, Żelazo 2006, Gorczyca 2016, Gorczyca $\mathrm{i}$ in. 2017).

\section{Współczesne uwarunkowania systemów koryt rzecznych}

Współczesne typy układów koryt rzecznych w Polsce są odbiciem ponadregionalnych (np. Wisła, Odra), regionalnych (np. Bug, Warta, Bzura, Pilica, Narew) lub lokalnych (dopływy Wisły i Odry, rzeki Przymorza) uwarunkowań przyrodniczych i ich zmienności w czasie. W efekcie dużego zróżnicowania środowiska przyrodniczego i długotrwałej działalności człowieka na obszarze Polski, w obrębie dziewięciu makroregionów można wyróżnić 12 typów koryt oraz dodatkowo 7 typów dla rzek tranzytowych, przecinających wszystkie strefy morfogenetyczne (ryc. 14). W typologii tej zastosowano podejście fizjograficzne (Klimek 1991, Kaszowski, Krzemień 1986, 1999) i wyróżniono następujące typy (Andrzejewski, Krzemień 2017):

- koryta w obszarach górskich i wyżynnych, 5 typów: 1 - koryta wysokogórskie (ryc. 15), 2 - koryta średniogórskie (koryta wschodniobeskidzkie (ryc. 16), zachodniobeskidzkie (ryc. 17), sudeckie (ryc. 18)), 3 - koryta pogórskie i kotlin śródgórskich (ryc. 19), 4 - koryta kotlin przedgórskich (ryc. 20), 5 - koryta wyżynne (seminaturalne, uregulowane (ryc. 21a, b)); 


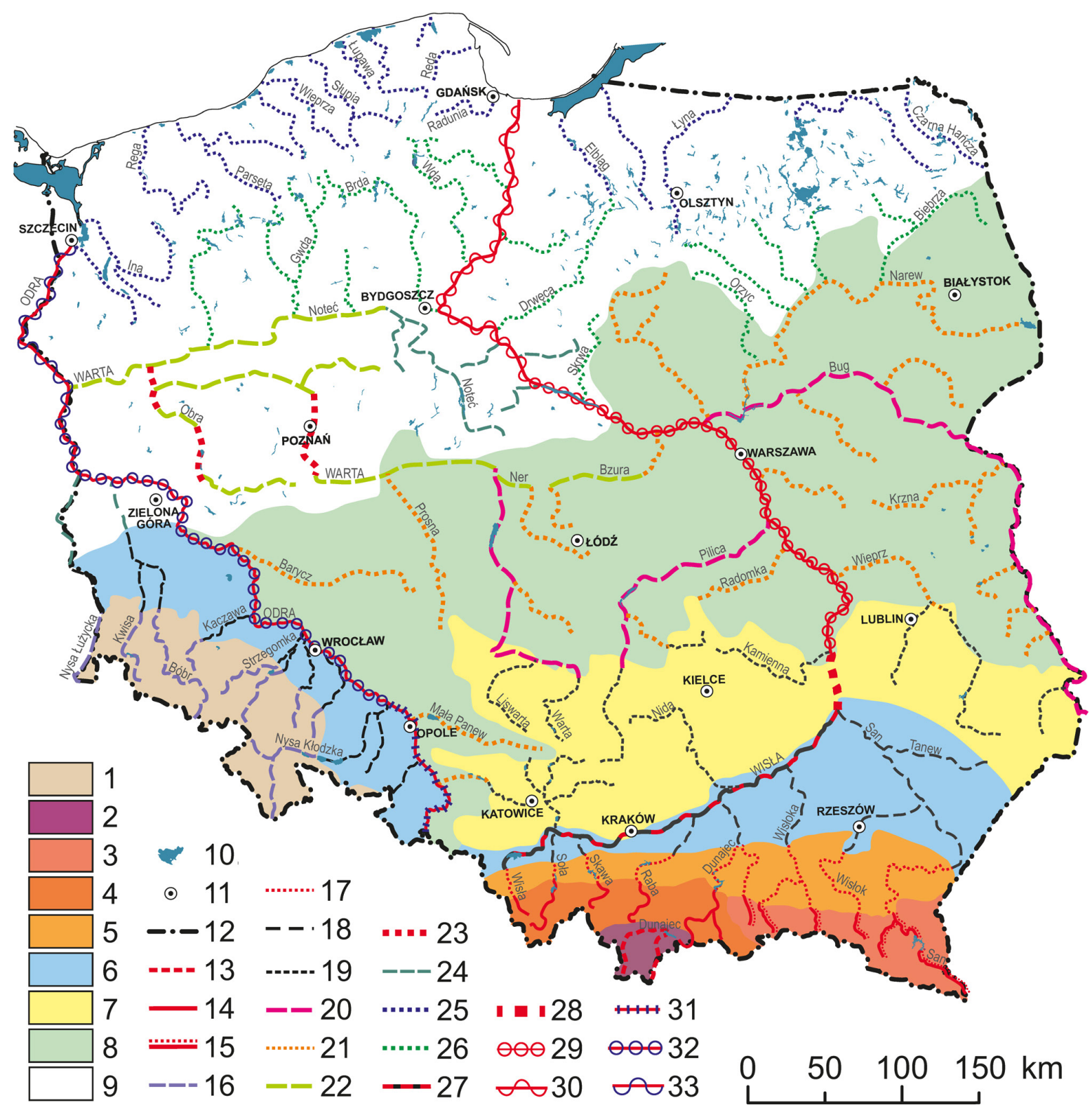

Ryc. 14. Rozmieszczenie typów koryt w Polsce (Andrzejewski, Krzemień 2017)

1 - Sudety z Przedgórzem Sudeckim, 2 - Tatry z Podhalem, 3 - obszar wschodniobeskidzki, 4 - obszar zachodniobeskidzki, 5 - Pogórze Karpackie, 6 - kotliny i obszary przedgórskie, 7 - Wyżyny Polskie, 8 - obszar staroglacjalny, 9 - obszar młodoglacjalny, 10 - jeziora i zbiorniki wodne, 11 - większe miasta, 12 - granica państwa, rodzaje koryt rzecznych: 13 - o reżimie wysokogórskim, 14 - średniogórskich, zachodniobeskidzikich, 15 - średniogórskich, wschodniobeskidzikich, 16 - sudeckich, 17 - pogórskich (Pogórza Karpackiego), 18 - kotlin i obszarów przedgórskich, 19 - wyżynnych, 20 - krętych lub meandrujących rzek „tranzytowych”, ponadregionalnych, 21 - krętych lub meandrujących rzek „autonomicznych”, 22 - ukształtowanych w obrębie równoleżnikowych dolin marginalnych lub pradolin (w obszarach: staroglacjalnym i młodoglacjalnym), 23 - w dolinach przełomowych, najczęściej o układzie południkowym, 24 - dopływów dużych rzek tranzytowych (Wisła, Odra), 25 - północnego skłonu garbu pojeziernego, 26 - południowego skłonu garbu pojeziernego, 27 - Wisły w odcinku górnym, 28 - Wisły w przełomie przez wyżyny, 29 - Wisły w odcinku mazowieckim, 30 - Wisły w odcinku kujawsko-pomorskim, 31 - górnej Odry, 32 - środkowej Odry, 33 - dolnej Odry

Fig. 14. Spatial distribution of river channels in Poland (Andrzejewski, Krzemień 2017)

1 - the Sudety Mountains and Sudety Foothills, 2 - the Tatras with Podhale, 3 - eastern area of the Beskids, 4 - western area of the Beskids, 5 - the Carpathian Foothills, 6 - basins and foreland areas, 7 - Polish Uplands, 8 - old postglacial area, 9 - young postglacial area, 10 - lakes and reservoirs, 11 - main cities, 12 - state border, 13 - high-mountain river channels, 14 - mid-altitude mountain channels in the Western Beskids, 15 - mid-altitude mountain channels in the Eastern Beskids, 16 - Sudetes river channels, 17 - foothill river channels (Carpathian Foothills), 18 - foreland basins and channels, 19 - upland channels, 20 - winding or meandering channels of 'transit' or trans-regional rivers, 21 - winding or meandering channels of 'autonomous' rivers, 22 - channels formed within latitudinal marginal or pradolina (ice-marginal streamway) valleys (in old-glacial and young-glacial areas), 23 - breakthrough channels, mainly with meridional orientation, 24 - channels of tributaries of large transit rivers (the Vistula and the Odra), 25 - channels on the northern slopes of lake-district ridge, 26 - channels on the southern slopes of lake-district ridge, 27 - upper-section Vistula river channel, 28 - Vistula river channel cutting across uplands, 29 - Vistula river channel in the Mazowieckie Province, 30 - Vistula river channel in the Kujawsko-Pomorskie Province, 31 - upper Odra river channel, 32 - middle-Odra river channel, 33 - lower-Odra river channel 


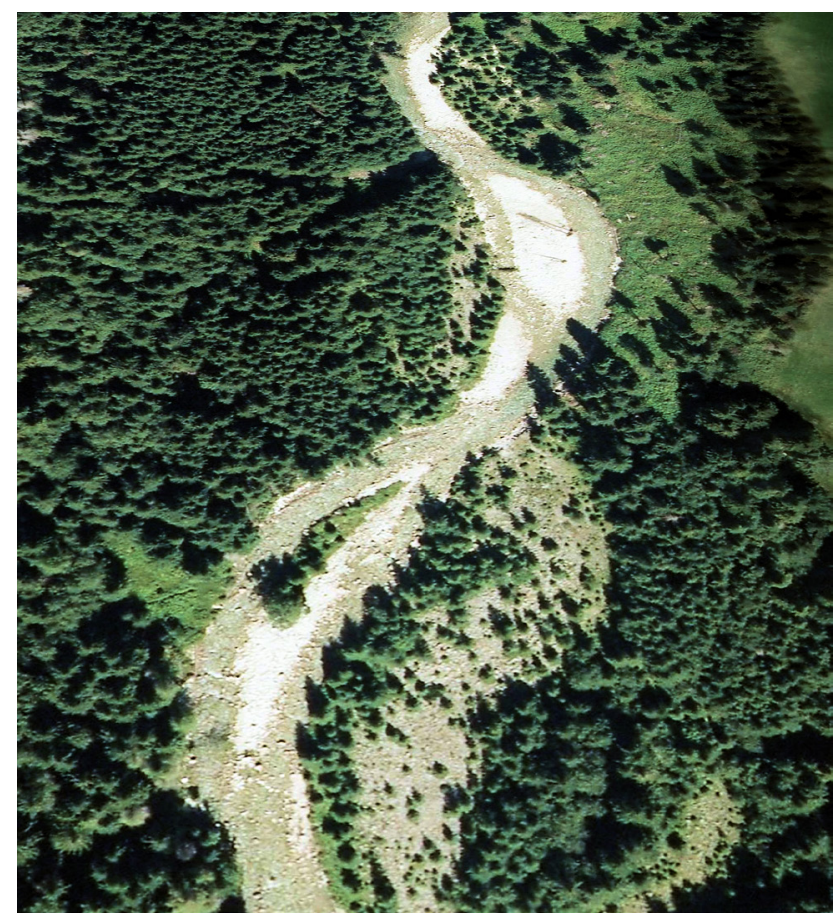

Ryc. 15. Koryta rzek wysokogórskich - Rybi Potok koło Roztoki (Google Maps 2018)

Fig. 15. Channels of mountain rivers - Rybi Stream near Roztoka (Google Maps 2018)
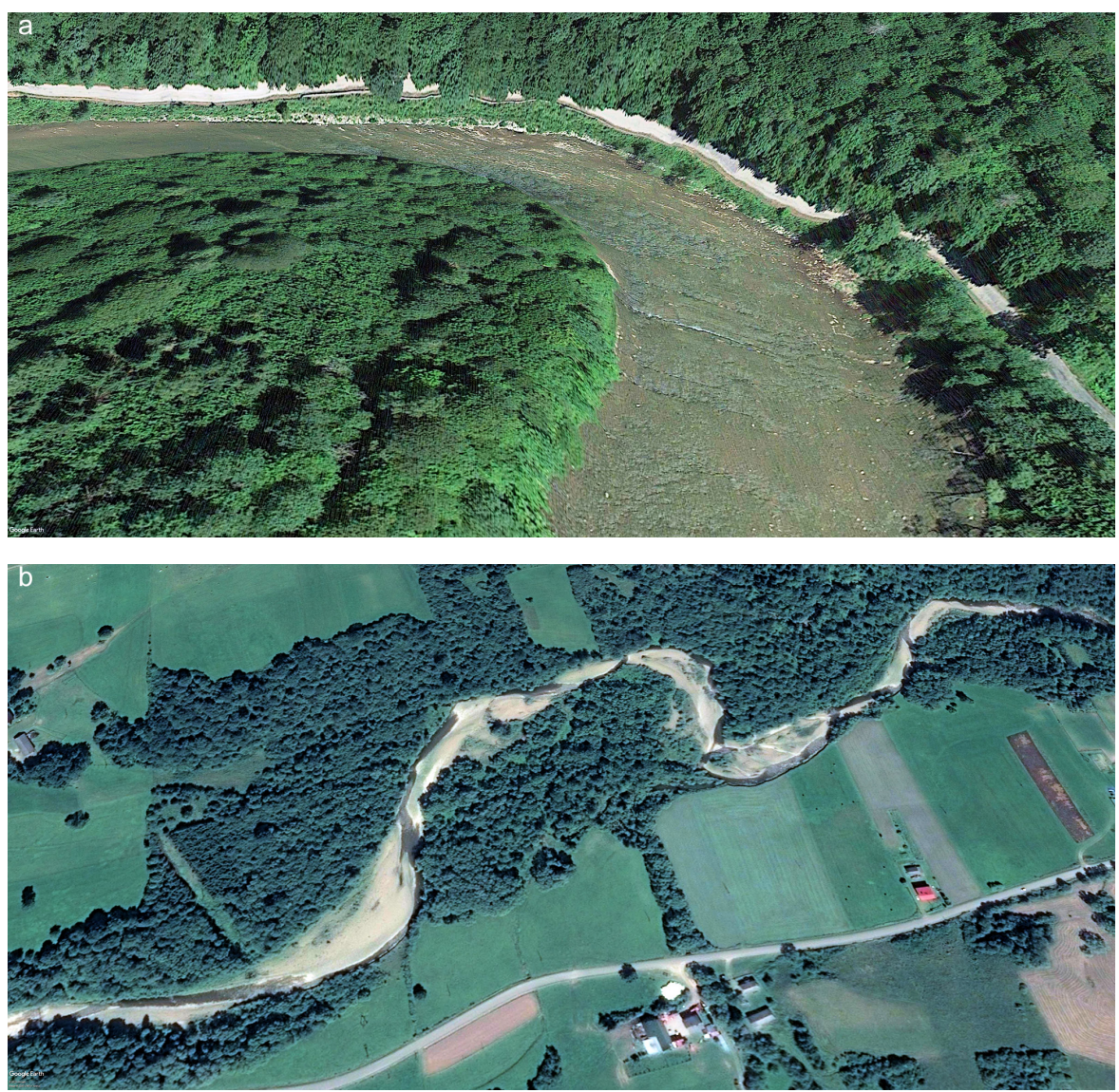

Ryc. 16. Wschodniobeskidzkie koryta średniogórskie (Google Maps 2018)

a) koryto skalne erozyjne z berdami - San poniżej Zatwarnicy, b) koryto aluwialne - Wisłoka koło Świątkowej Małej

Fig. 16. East-Beskids highland river channels (Google Maps 2018)

a) erosion bedrock channel with rapids - San River below Zatwarnica, b) alluvial channel - Wisłoka River near Świątkowa Mała 


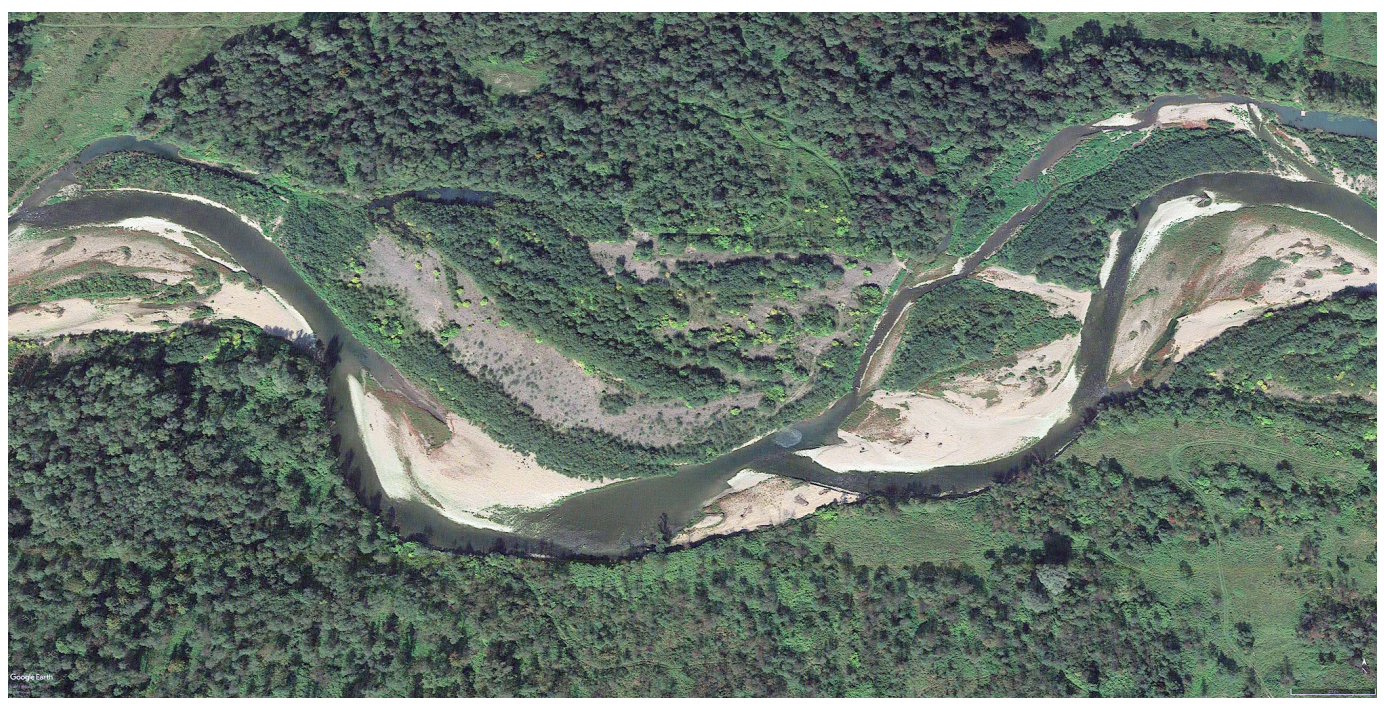

Ryc. 17. Zachodniobeskidzkie koryta średniogórskie - Skawa miedzy Makowem Podhalańskim a Suchą Beskidzką (Google Maps 2018)

Fig. 17. West-Beskids highland river channels - Skawa River between Makow Podhalański and Sucha Beskidzka (Google Maps 2018)

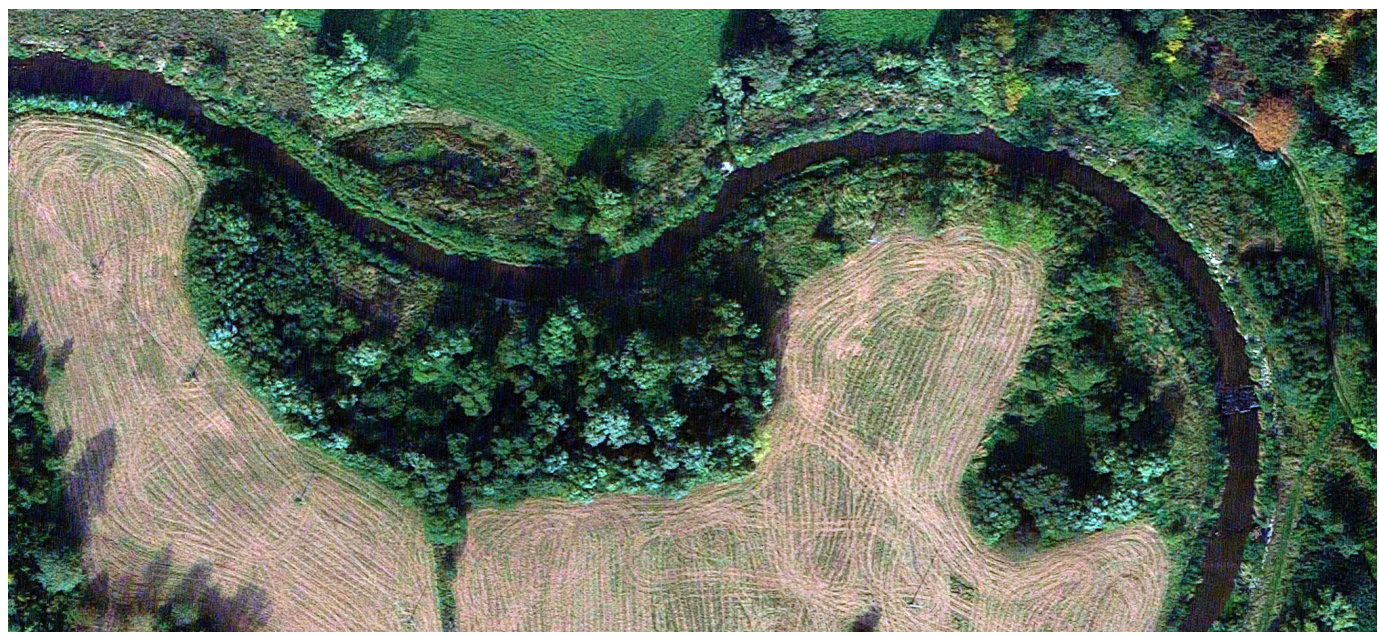

Ryc. 18. Sudeckie koryta średniogórskie - Nysa Kłodzka powyżej Domaszkowa (Google Maps 2018)

Fig. 18. Sudetes highland river channels - Nysa Kłodzka River above Domaszków (Google Maps 2018)

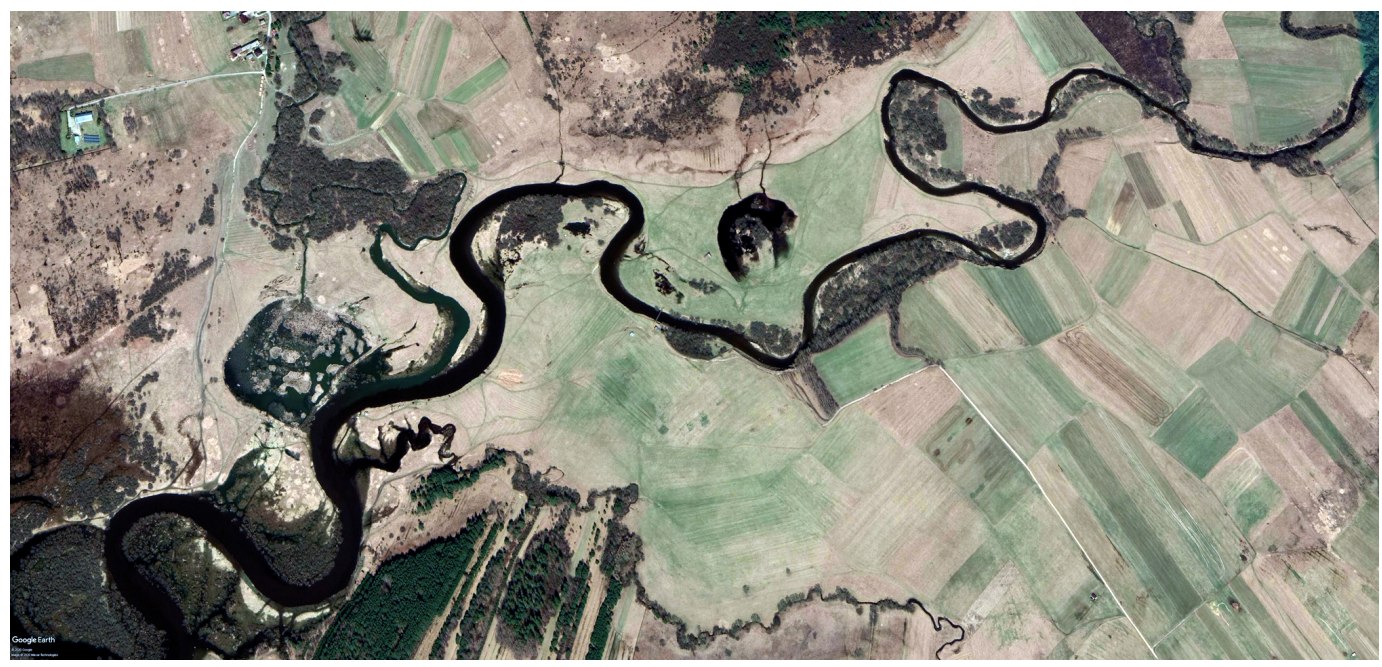

Ryc. 19. Koryta kotlin śródgórskich - Czarna Orawa koło Jabłonki (Google Maps 2018)

Fig. 19. River channels in mid-mountain basins - Czarna Orawa River near Jabłonka (Google Maps 2018) 


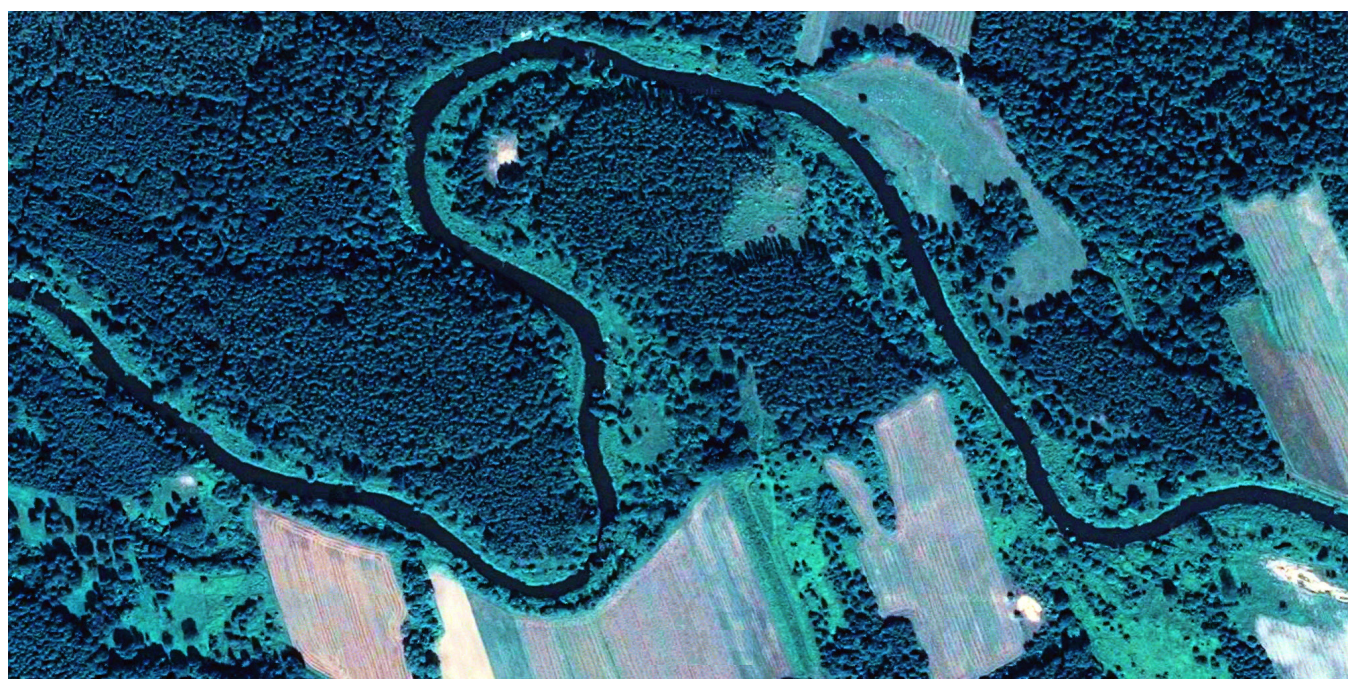

Ryc. 20. Koryta kotlin przedgórskich - Tanew poniżej Wólki Biskiej (Google Maps 2018)

Fig. 20. River channels of foothill basins - Tanew River below Wólka Biska (Google Maps 2018)
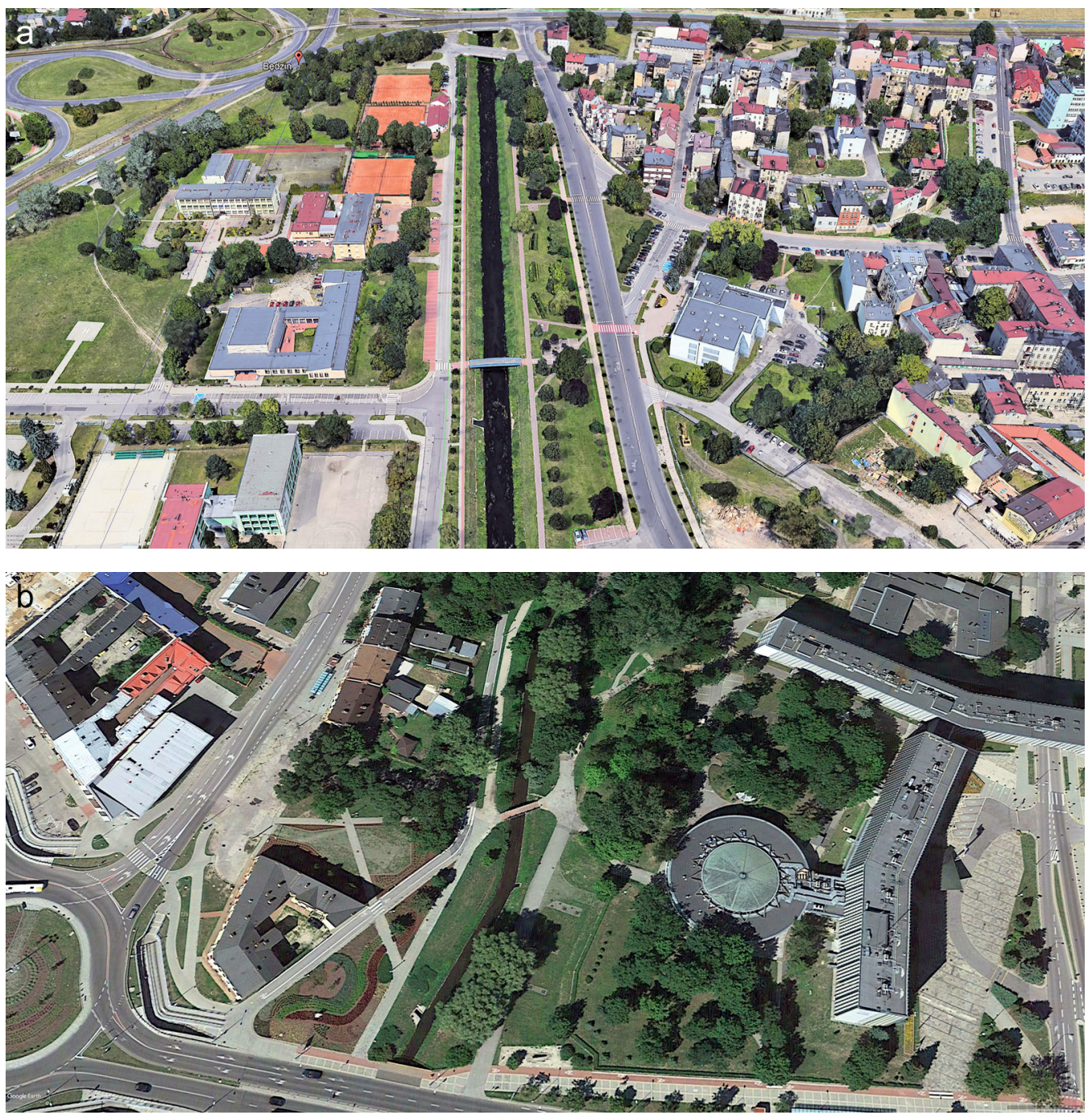

Ryc. 21. Koryta wyżynne seminaturalne i uregulowane (Google Maps 2018)

a) Przemsza w Będzinie, b) Silinica w Kielcach

Fig. 21. Seminatural and regulated upland river channels (Google Maps 2018)

a) Przemsza River in Będzin, b) Silinica River in Kielce 


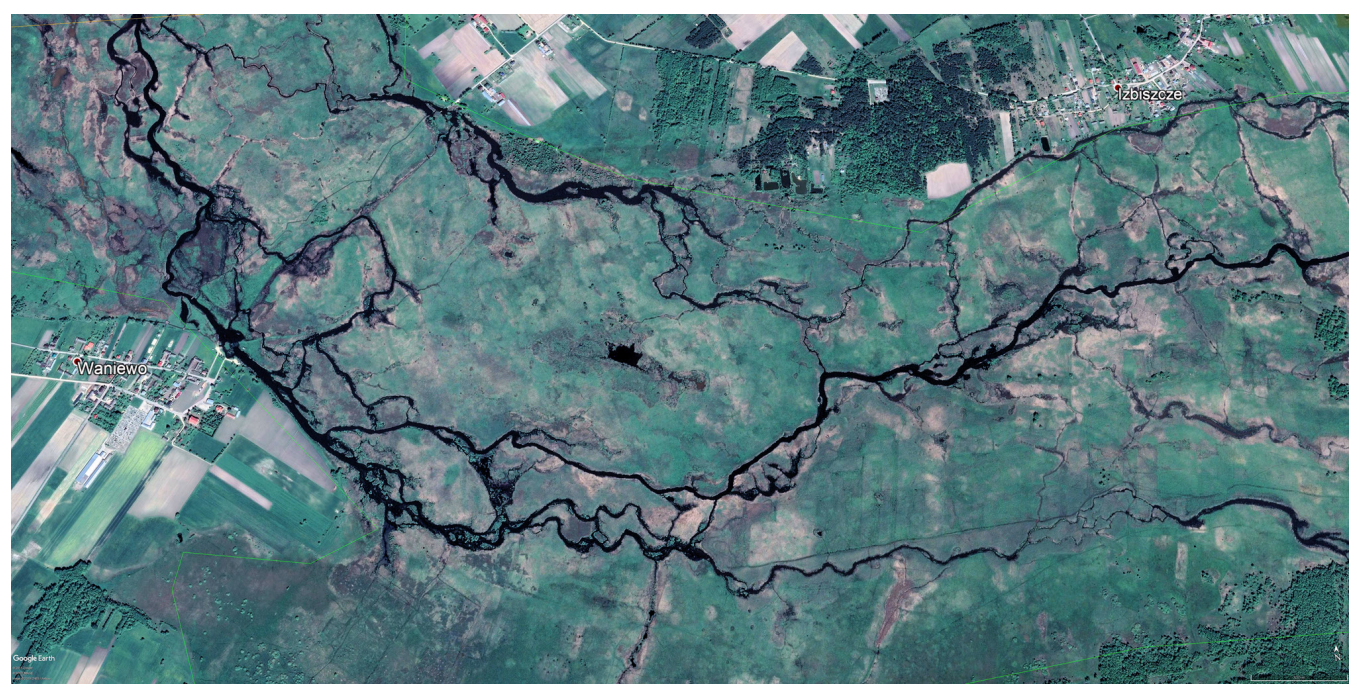

Ryc. 22. Koryta rzek autochtonicznych: anastomozujące - Narew koło Waniewa (Google Maps 2018)

Fig. 22. Channels of autochthonic rivers: anastomosing - Narew River near Waniewa (Google Maps 2018)

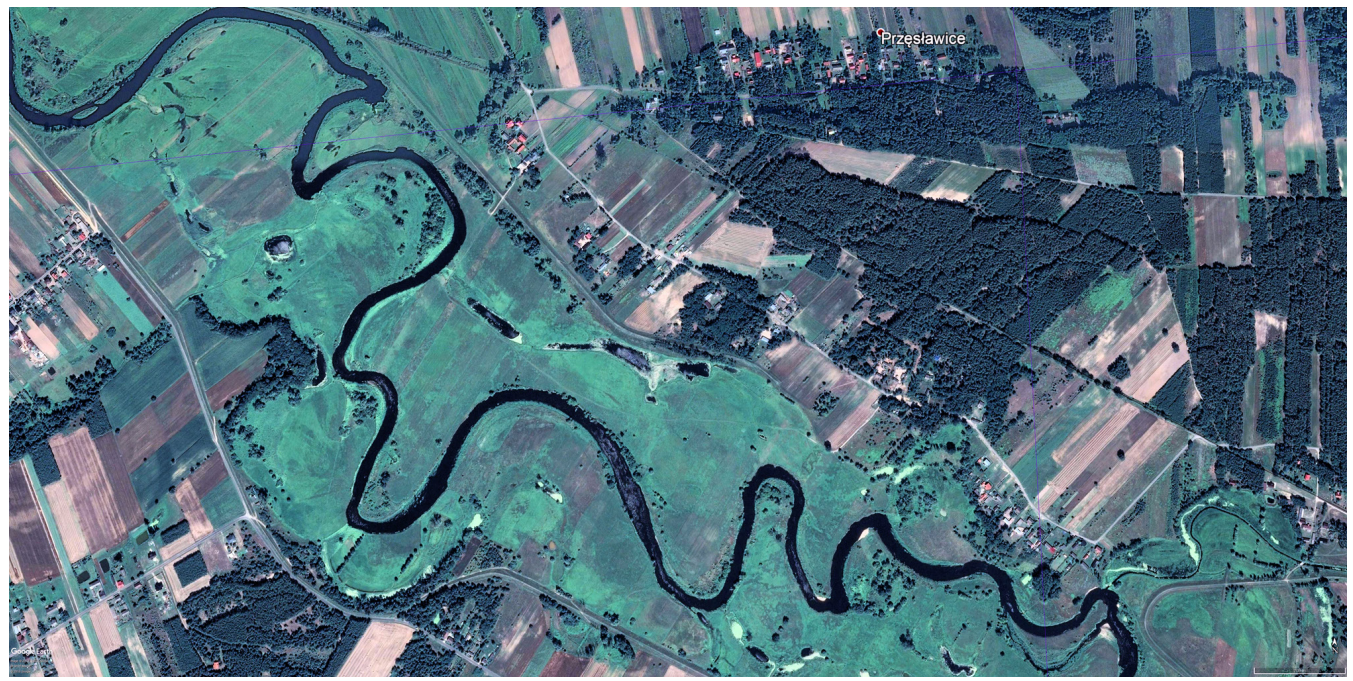

Ryc. 23. Koryta rzek autochtonicznych: dolin marginalnych i pradolinne - Bzura koło Łasic (Google Maps 2018)

Fig. 23. Channels of autochthonic rivers: marginal valleys and pradolinas - Bzura River near Łasice (Google Maps 2018)

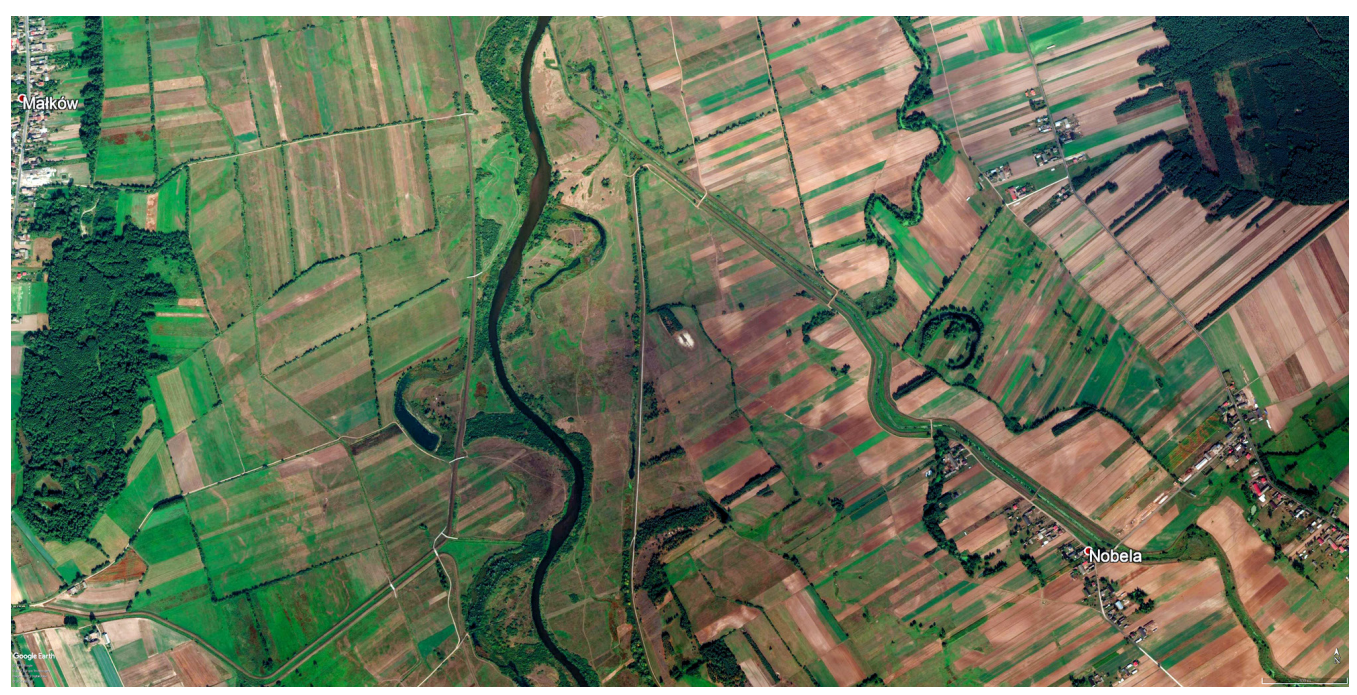

Ryc. 24. Koryta rzek allochtonicznych - Warta poniżej Nobeli (Google Maps 2018)

Fig. 24. Channels of allochthonic rivers - Warta River below Nobela (Google Maps 2018) 
- koryta w obszarze staroglacjalnym, 2 typy koryt krętych lub meandrujących: 1 - koryta rzek autochtonicznych (koryta anastomozujące (ryc. 22), koryta dolin marginalnych i pradolinne (ryc. 23)), 2 - koryta rzek allochtonicznych (bez koryt rzek tranzytowych (ryc. 24));

- koryta w obszarze młodoglacjalnym, 5 typów najczęściej koryt krętych lub meandrujących: 1 koryta południowego skłonu garbu pojeziernego (koryta z jeziorami przepływowymi (ryc. 12), koryta szerokich równin aluwialnych (ryc. $25 \mathrm{a}, \mathrm{b})$ ), 2 - koryta północnego skłonu garbu pojeziernego (koryta dolin przełomowych (ryc. 26a) i koryta w dnach zagłębień wytopiskowych (ryc. 26b)), 3 - koryta w obrębie równoleżnikowych dolin marginalnych (ryc. 27) lub pradolin (ryc. 28a, b), 4 - koryta $\mathrm{w}$ dolinach przełomowych o układzie południkowym lub zbliżonym (ryc. 29), 5 - koryta dopływów dużych rzek tranzytowych: koryta w obrębie teras dolin rzek tranzytowych (ryc. 30a, b), koryta w obrębie wysoczyzn, sandrów (ryc. 30c) i dolin przełomowych lub zagłębien polodowcowych (ryc. 30d);

- koryta dużych rzek tranzytowych (Wisła, Odra), 7 typów: A. Wisła (Plit, Warowna 2008): 1 - koryto na odcinku do ujścia Sanu (ryc. 31), 2 - koryto w przełomie przez pas wyżyn (ryc. 32 ), 3 - koryto na odcinku mazowieckim (ryc. 33), 4 - koryto na odcinku kujawsko-pomorskim (ryc. 34); B. Odra (Ciszewski, Dubicki 2008): 1 - koryto na odcinku
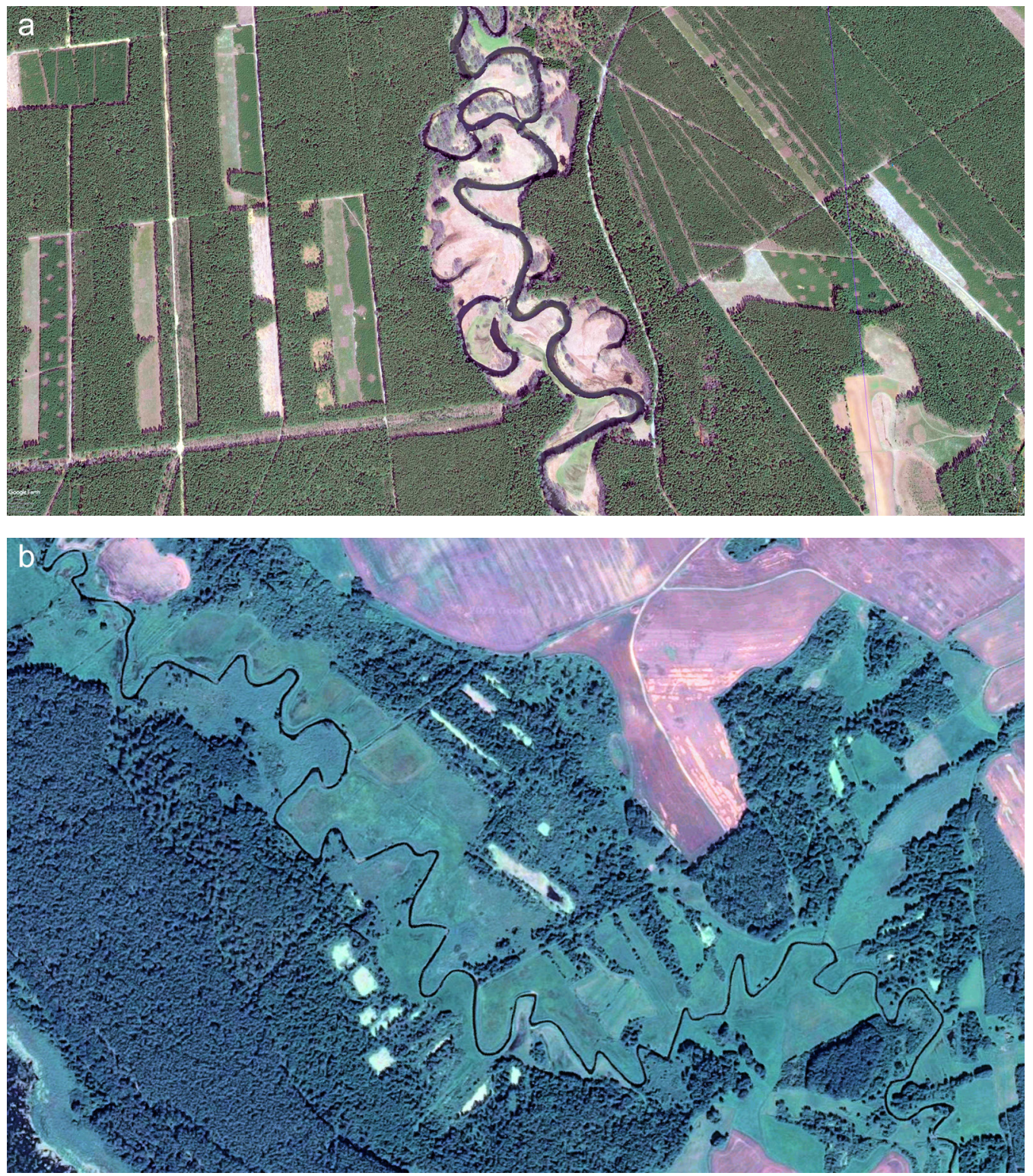

Ryc. 25. Koryta południowego skłonu garbu pojeziernego: koryta szerokich równin aluwialnych (Google Maps 2018)

a) Brda poniżej Woziwody, b) Wel koło Grodziczna

Fig. 25. River channels of the southern slope of the lakeland ridge: river channels of wide alluvial plains (Google Maps 2018) a) Brda River below Woziwoda, b) Wel River near Grodziczno 

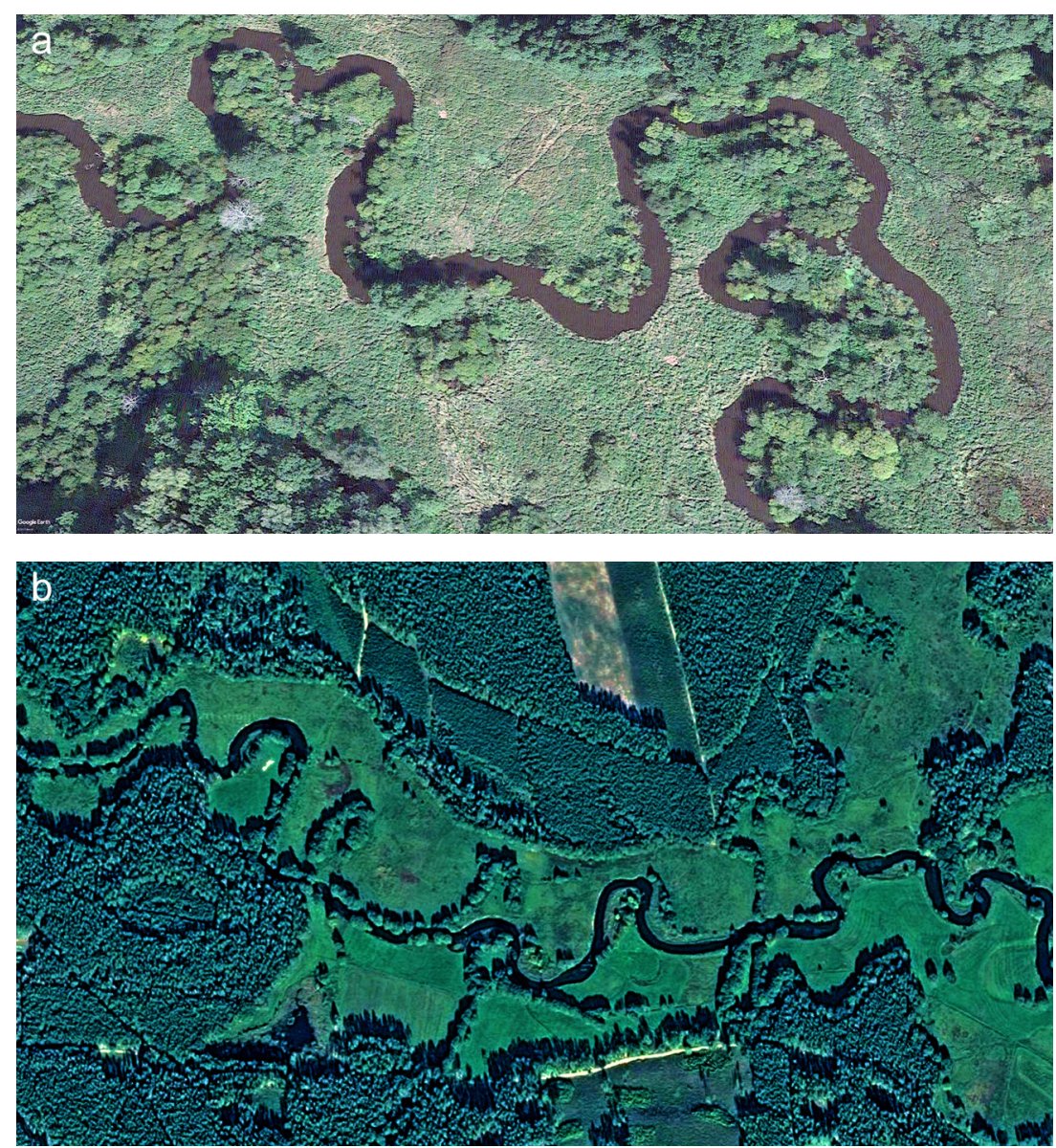

Ryc. 26. Koryta północnego skłonu garbu pojeziernego (Google Maps 2018)

a) koryta dolin przełomowych - Parsęta powyżej Wicewa, b) koryta w dnach zagłębień wytopiskowych - Słupia koło Dębnicy Kaszubskiej

Fig. 26. River channels of the northern lakeland ridge (Google Maps 2018)

a) channels of river breakthrough valley - Parsęta River above Wicewo, b) river channels in the bottom of the kettle hole - Słupia River near Dębnica Kaszubska

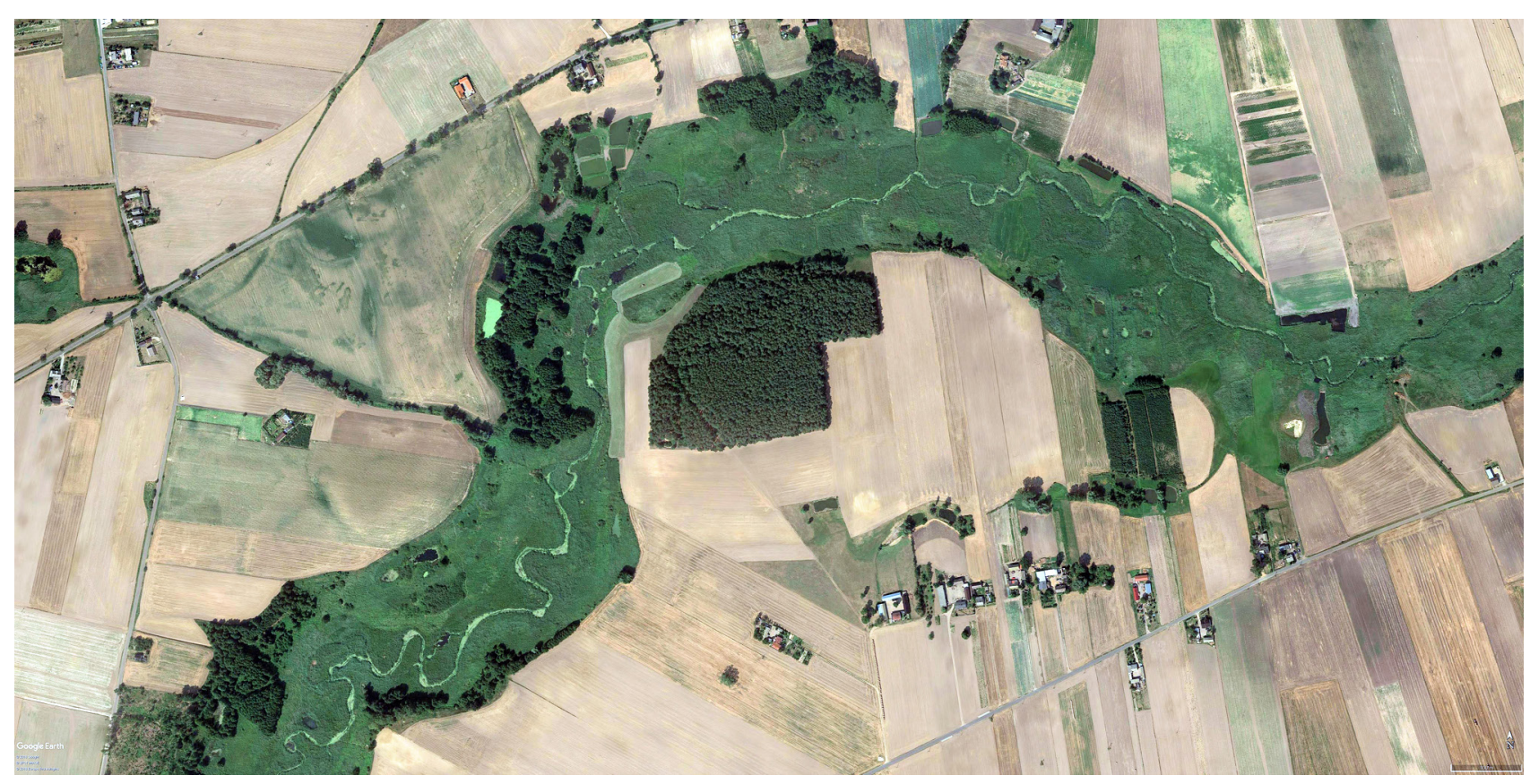

Ryc. 27. Koryta w obrębie równoleżnikowych dolin marginalnych - Zgłowiączka koło Żydowa (Google Maps 2018)

Fig. 27. River channels within latitudinal marginal valleys - Zgłowiączka River near Żydów (Google Maps 2018) 

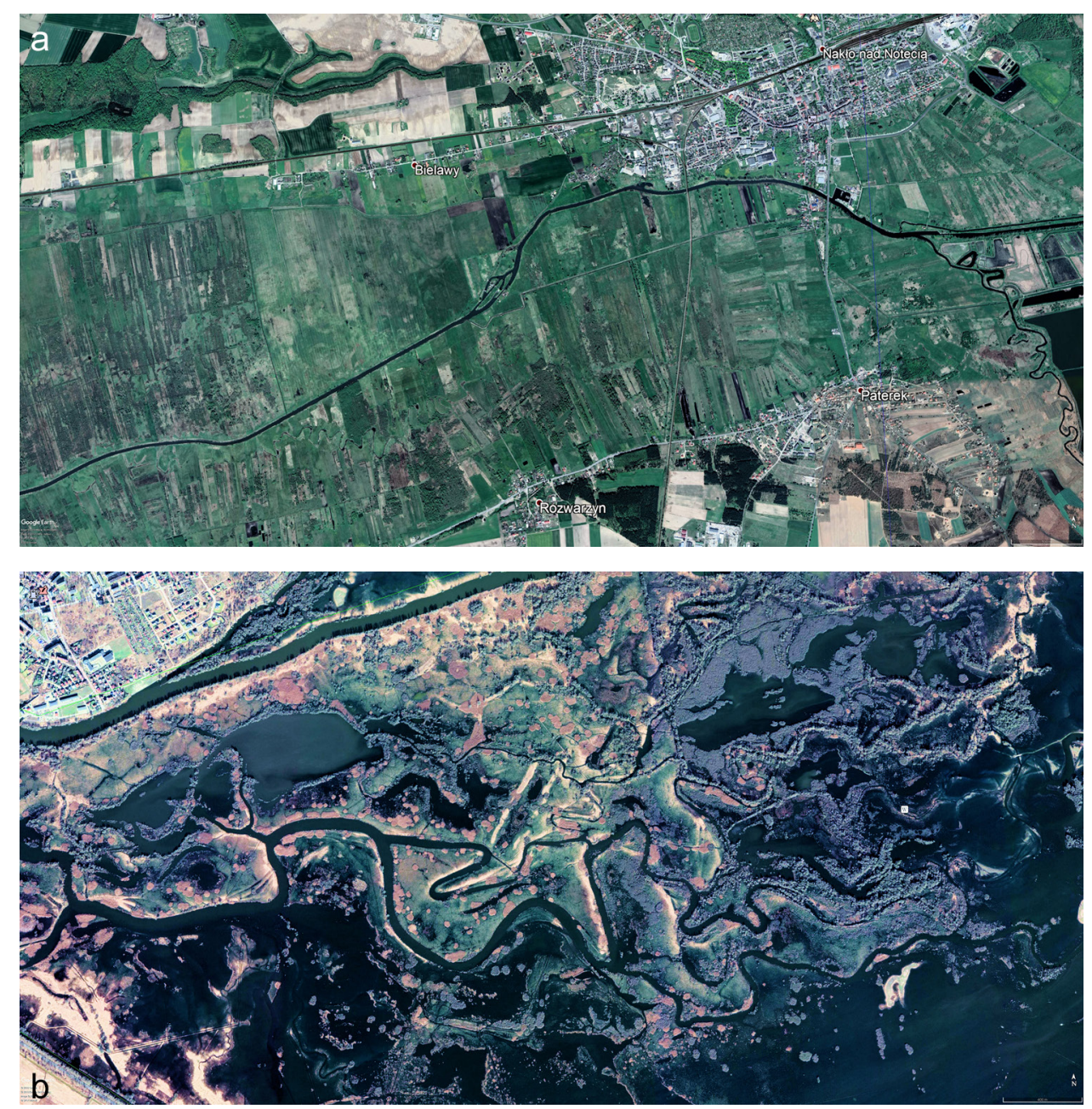

Ryc. 28. Koryta w obrębie równoleżnikowych pradolin (Google Maps 2018)

a) Noteć poniżej Nakła nad Notecią, b) Warta przy ujściu do Odry

Fig. 28. River channels within latitudinal pradolinas (ice-marginal streamways) (Google Maps 2018)

a) Noteć River below Nakło nad Notecią, b) Warta River at the mouth of the Oder

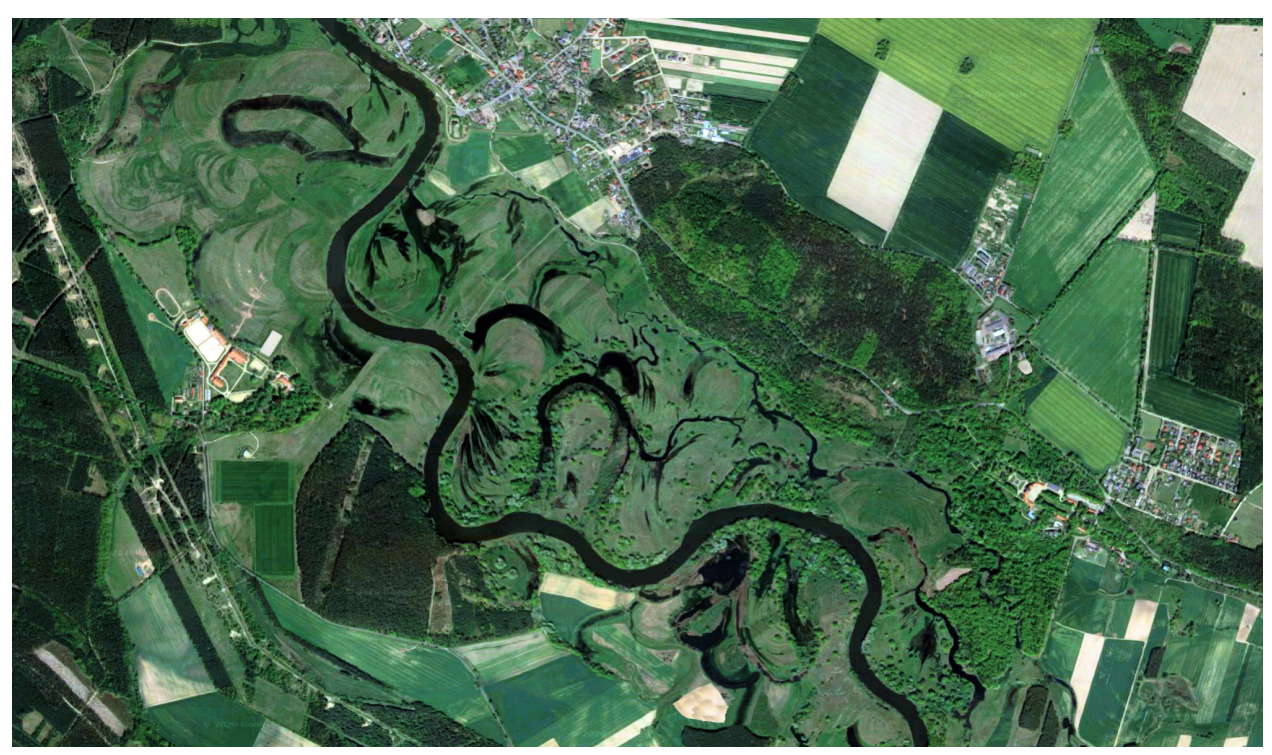

Ryc. 29. Koryto Warty w obrębie równoleżnikowej pradoliny Warszawsko-Berlińskiej pomiędzy Rogalinem a Rogalinkiem (Google Maps 2018)

Fig. 29. The Warta River channel within the latitudinal Warsaw-Berlin Pradolina between Rogalin and Rogalinek (Google Maps 2018) 

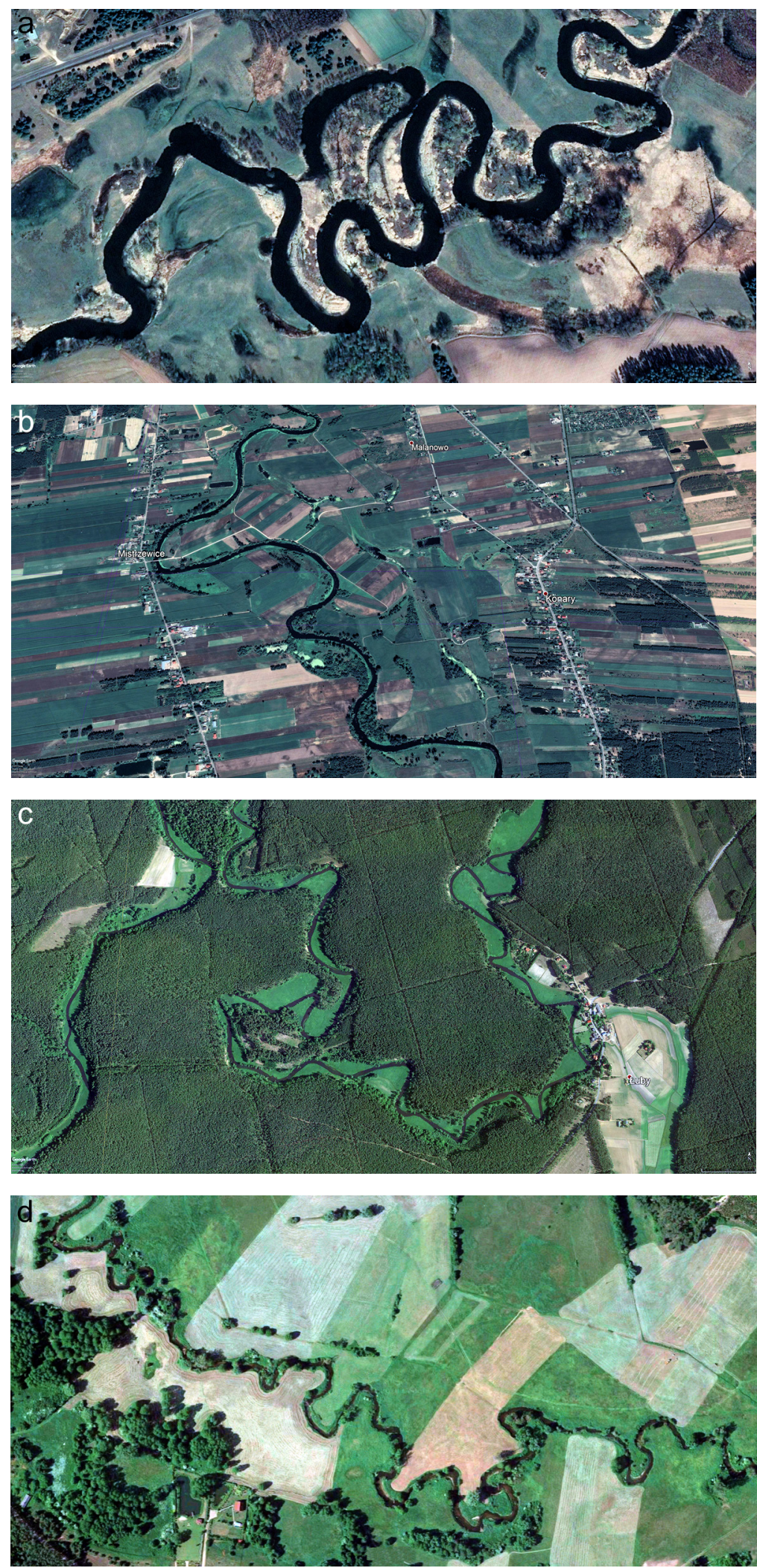

Ryc. 30. Koryta dopływów dużych rzek tranzytowych (Google Maps 2018)

a) koryta w obrębie teras dolin rzek tranzytowych - Drwęca poniżej Golubia-Dobrzynia, b) Bzura przed ujściem do Wisły, c) koryta w obrębie wysoczyzn, sandrów - Wda koło Łub, d) dolin przełomowych lub zagłębień polodowcowych - Zgłowiączka powyżej Włocławka

Fig. 30. Tributaries of large transit rivers (Google Maps 2018)

a) river channels within the terraces of transit river valleys - Drwęca River below Golub-Dobrzyń, b) Bzura River before the mouth to the Vistula, c) river channels within the morainic uplands, outwash plains - Wda River near Łub, d) channels of river breakthrough valley or postglacial depressions - Zgłowiączka River above Włocławek 


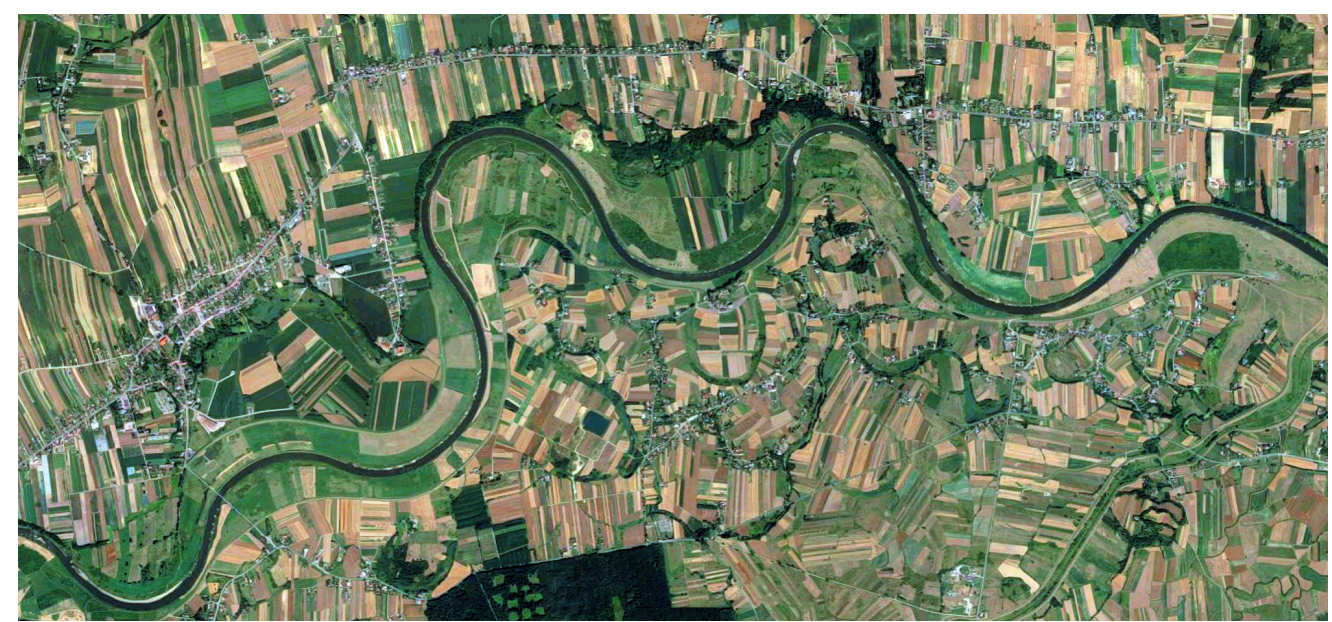

Ryc. 31. Koryto Wisły na odcinku do ujścia Sanu poniżej Nowego Brześcia (Google Maps 2018)

Fig. 31. Channel of the Vistula River on the section to the mouth of the San River below Nowy Brześć (Google Maps 2018)

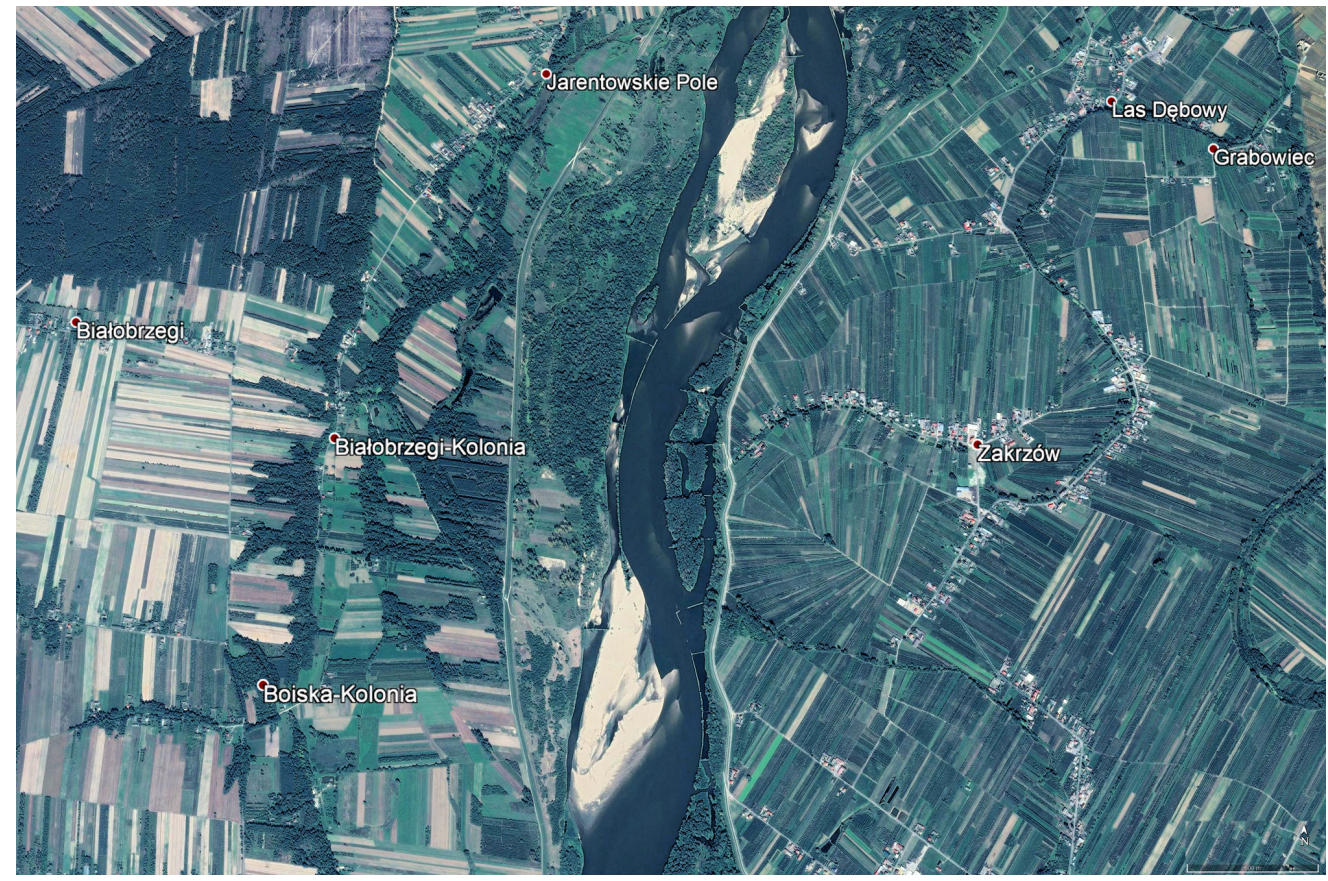

Ryc. 32. Koryto Wisły w przełomie przez pas wyżyn powyżej Kazimierza Dolnego (Google Maps 2018)

Fig. 32. Channel of the Vistula River at the river breakthrough of the uplands above Kazimierz Dolny (Google Maps 2018)

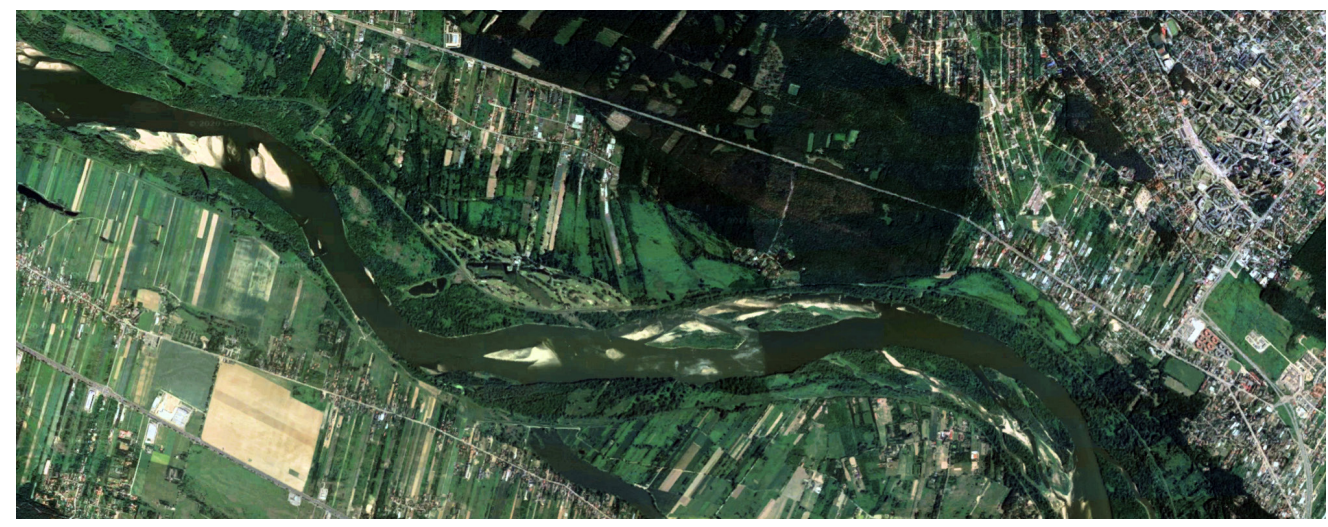

Ryc. 33. Koryto Wisły na odcinku mazowieckim poniżej Jabłonnej (Google Maps 2018)

Fig. 33. Channel of the Vistula River on the Mazovian section below Jabłonna (Google Maps 2018) 
górnej Odry po Nysę Kłodzką (ryc. 35), 2 - koryto na odcinku Odry środkowej do Słubic (ryc. 36), 3 - koryto na odcinku dolnej Odry (ryc. 37).

Koryta rzek górskich charakteryzują się bardzo dużym zróżnicowaniem i obejmują swym zasięgiem Karpaty i Sudety. W obszarach tych agradacja w dnach dużych rzek została zastąpiona ok. 100 lat temu (Starkel, Łajczak 2008), a w Sudetach nawet 150 lat temu (Chmal 2002, Latocha 2007), stopniowym pogłębianiem i zwężaniem koryt (Gorajska 2014). W tym okresie zachodziła intensywna erozja, stopniowo w korytach rzek głównych, a następnie w ich dopływach, głównie na skutek prac regulacyjnych, budowy zbiorników zaporowych różnej wielko-

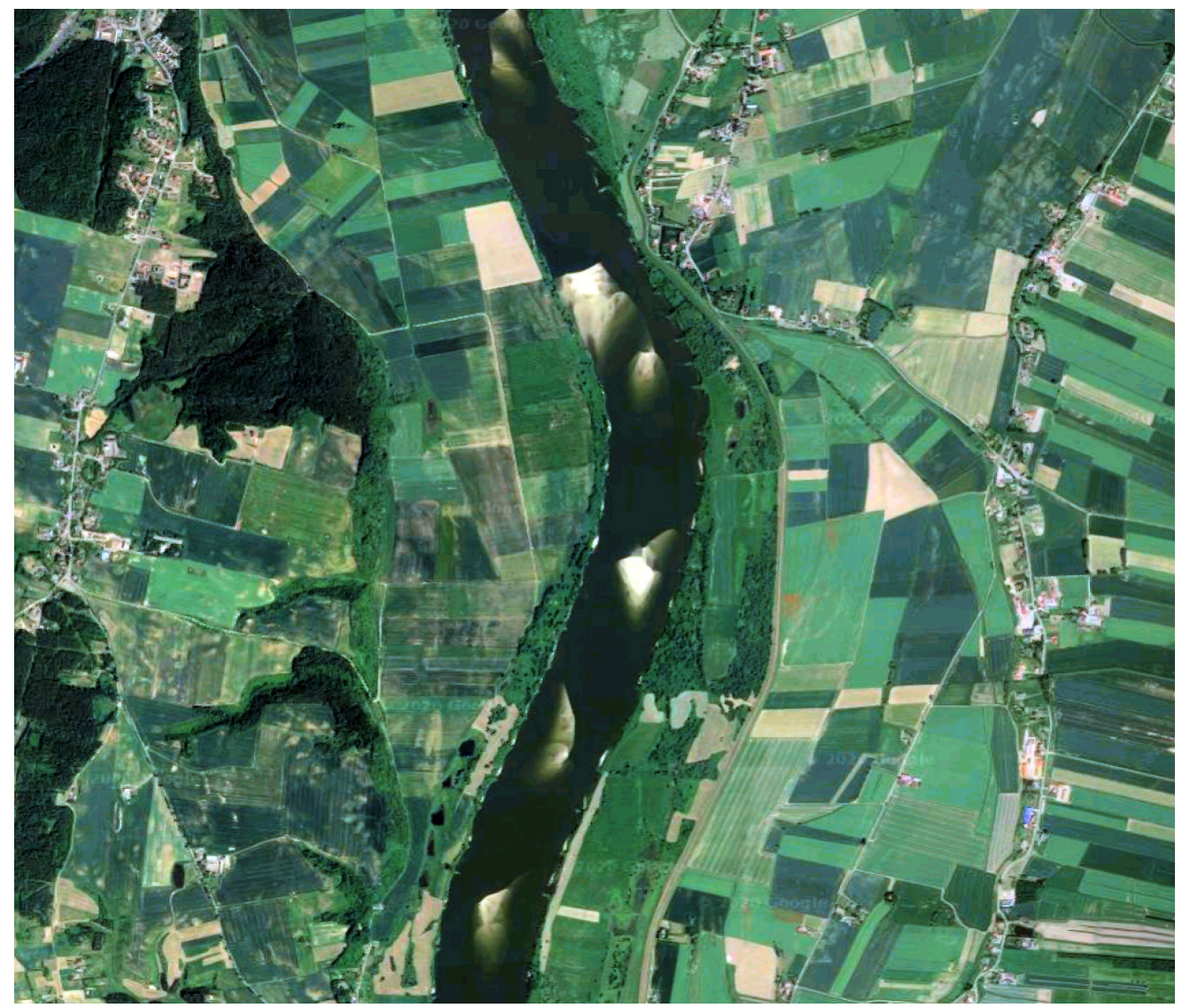

Ryc. 34. Koryto Wisły na odcinku kujawsko-pomorskim powyżej Gniewu (Google Maps 2018)

Fig. 34. Channel of the Vistula River on the Kuyavian-Pomeranian section above Gniew (Google Maps 2018)

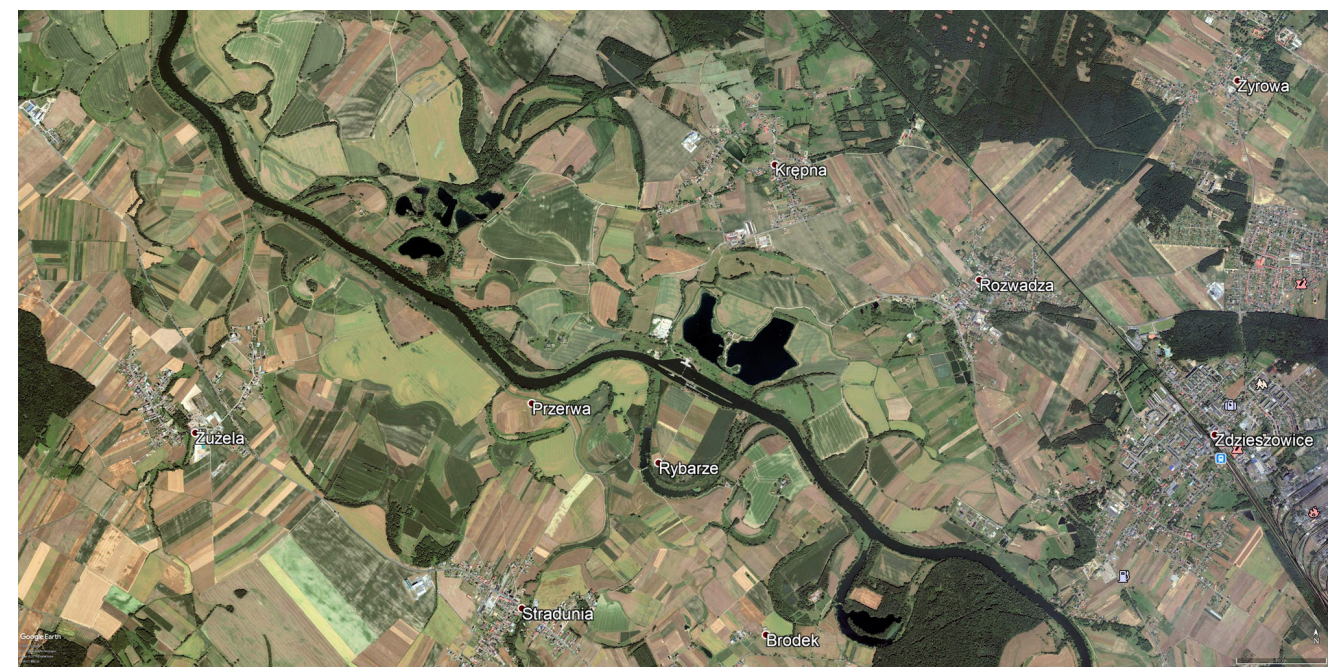

Ryc. 35. Koryto Odry na odcinku górnej Odry po Nysę Kłodzką poniżej Zdzieszowic (Google Maps 2018)

Fig. 35. Channel of the Odra River on the section of the upper Odra up to Nysa Kłodzka below Zdzieszowice (Google Maps 2018) 
ści, eksploatacji rumowiska, zmniejszenia transportu rumowiska na skutek zmian użytkowania ziemi itp. Proces ten przebiegał na dużą skalę przede wszystkim w Karpatach (Łajczak i in. 2014). W efekcie w dolnych i środkowych odcinkach karpackich dopływów Wisły koryta zostały pogłębione nawet o 2-4 m (Kaszowski i in. 1976, Klimek 1983, 1987, Krzemień 2003, Starkel, Łajczak 2008, Zawiejska, Wyżga 2008, 2010, Zawiejska i in. 2015, Gorczyca 2016, Gorczyca i in. 2017). Pogłębianie koryt zaznacza się również w dolinach bocznych w wyniku erozji wstecznej. Taka sytuacja prowadzi do niekorzystnych zmian środowiska przyrodniczego $\mathrm{w}$ dnach dolin, związanych $\mathrm{z}$ nadmiernym przesuszaniem wielu obszarów. W efekcie tych przemian koryta rzek i potoków w wielu odcinkach zostały zmienione ze żwirodennych w skalne oraz z roztokowych $w$ błądzące lub kręte, docięte do litego podłoża (Wyżga 1993, Starkel, Łajczak 2008, Bucała 2012, Kukulak 2015, Witkowski, Wysmo- łek 2015, Zawiejska i in. 2015, Gorczyca i in. 2017). W warunkach niedociążenia przepływu wody, rzeki sudeckie wykazują również tendencję do wcinania i rozwoju meandrowego układu koryta (Kostrzewski 1970, Teisseyre 1977, 1979, Klimek, Latocha 2007, Latocha 2007, 2009, Migoń 2008).

Współcześnie w Karpatach zaobserwować można trzy typy dynamiczne profili podłużnych rzek i równin zalewowych (Łajczak i in. 2006, Starkel, Łajczak 2008, Andrzejewski, Krzemień 2017). Pierwszy typ rozpoczyna się $\mathrm{w}$ masywach górskich, do niedawna był o tendencjach roztokowych i o znacznym udziale rumowiska wleczonego, obecnie przegradzany zbiornikami retencyjnymi. Drugi typ występuje w obszarach niskich gór i pogórzy, na przeważającej długości profilu posiada tendencję do pogłębiania (Klimek 1983, Korpak i in. 2008, Wyżga i in. 2010) i cechuje się dominującym udziałem transportu zawiesiny i ograniczonej dostawie materiału ze zlewni na sku-

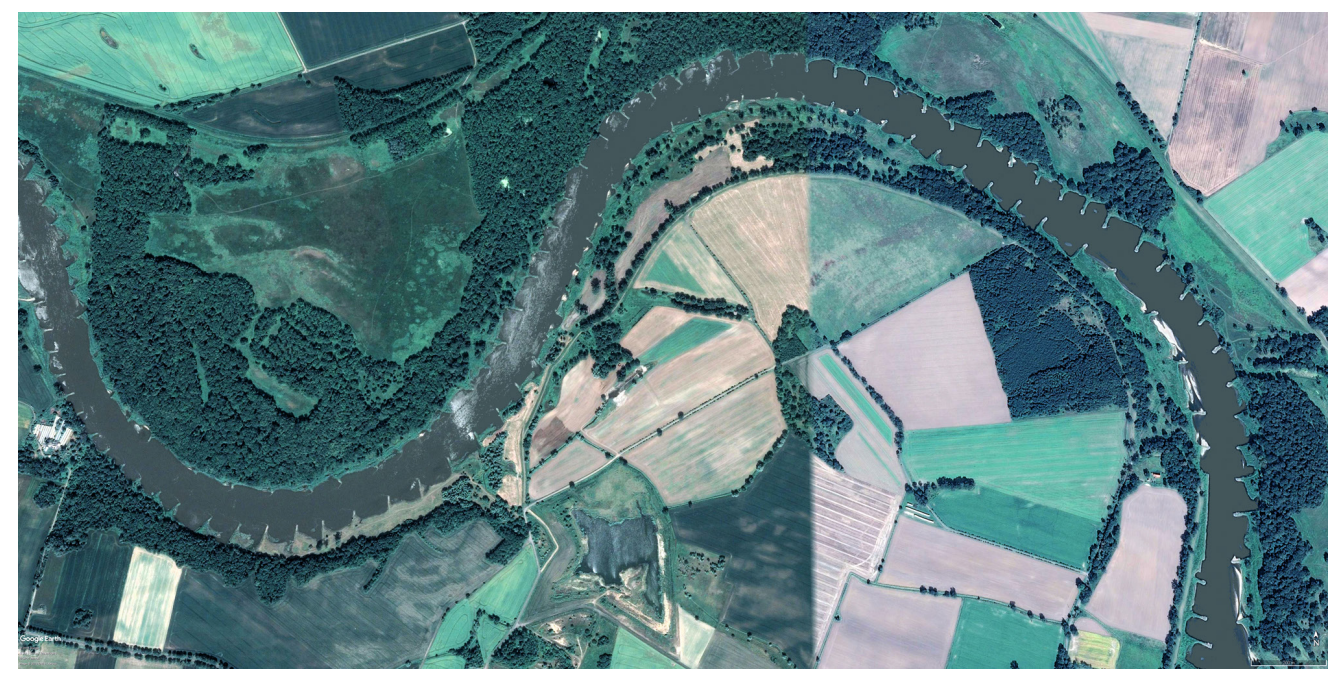

Ryc. 36. Koryto Odry na odcinku Odry środkowej do Słubic powyżej Bytomia Odrzańskiego (Google Maps 2018)

Fig. 36. Channel of the Odra River on the section of the middle Odra to Słubice above Bytom Odrzański (Google Maps 2018)

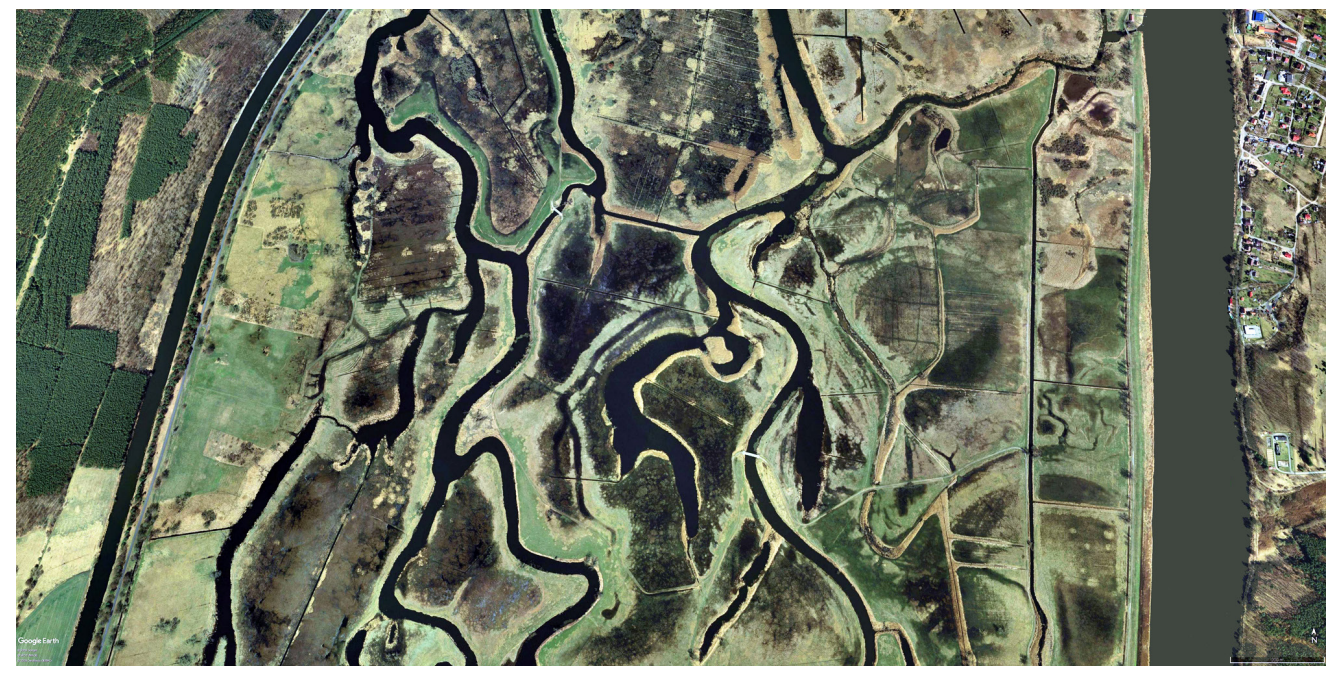

Ryc. 37. Koryto Odry w biegu dolnym powyżej Szczecina (Google Maps 2018)

Fig. 37. Channel of the Odra River in the lower course above Szczecin (Google Maps 2018) 
tek zmian w użytkowaniu ziemi. Trzeci typ dotyczy rzek pogórskich o częstych wezbraniach (wiosennych i letnich) i współczesnym postępującym nadbudowywaniu równin zalewowych (Klimek, Starkel 1974, Łajczak 1995, Gębica, Sokołowski 1999, 2001, Łajczak 1999, Kukulak 2004).

W korytach rzek sudeckich, obok uwarunkowań przyrodniczych, znaczący wpływ na funkcjonowanie systemów fluwialnych mają urządzenia hydrotechniczne (Witek 2012, Witek, Białobrzeska 2012). W obszarze tym podczas zdarzeń ekstremalnych stwierdzono znaczny udział rumowiska wleczonego w całkowitym transporcie rzecznym, które buduje układ erozyjnych i akumulacyjnych form powodziowych (Kostrzewski 1970, Teisseyre 1977, 1985, Zieliński 2003. Łach 2007, Kasprzak 2008, Pawlik 2010). Działania podjęte bezpośrednio po tego typu wezbraniach, polegające na zablokowaniu wlotów do przelewowych koryt powodziowych, a następnie ich zasypaniu i umocnieniu podcinanych brzegów, zmierzały dawniej i współcześnie do odtworzenia stanu sprzed wezbrania, ze stabilnym jednym krętym korytem (Migoń 2008).

W obrębie kotlin i obszarów przedgórskich Karpat, w warunkach naturalnych zostały wykształcone układy meandrowe rzek o małym spadku i zazwyczaj o małej szerokości w stosunku do głębokości (Klimek 1991), które współcześnie w większości uregulowano (Trafas 1992, Czaja i in. 1993, Witkowski, Wysmołek 2015). Taka sytuacja topograficzna sprzyja $z$ jednej strony pogłębianiu koryt rzecznych, ale $z$ drugiej strony $w$ trakcie wezbrań sprzyja intensywnym procesom nadbudowywania równiny zalewowej (Łajczak 1995) czy sedymentacji osadów pozakorytowych w międzywalu (Gębica i in. 1998, Łajczak 1999, Czajka 2000, 2007).

W pasie wyżyn można wyróżnić koryta rzeczne (lub ich odcinki) naturalne, seminaturalne i sztuczne (Kociuba 2007, Rodzik i in. 2008). Koryta sztuczne zróżnicowane są stopniem antropogenicznego przekształcenia, od prostego biegu poprzez skracanie zakoli (Kowalski 1988), poprzez budowę sztucznych i prostych odcinków rzeki (Ciupa 2001, Kociuba 2006a, b, Krupa 2013, Kociuba 2014), do formowania koryt krętych o złożonych parametrach geometrycznych. W szerokich dolinach aluwialnych, kształtowanych przez nieskrępowaną (naturalną) migrację boczną koryt, dominuje agradacja dna (Ciupa 1991, Kociuba 2002, Michno 2013). Lokalnie rzeki wykazują tendencję do meandrowania (Biała Nida, Biała Przemsza, Wieprz) oraz formowania układów wielokorytowych (Harasimiuk 1991, Sołtysik 2002, Fajer 2004). W odcinkach przewężeń i progów strukturalnych w dnie doliny rozwój boczny koryt jest ograniczony, a meandrowanie rzek często jest wymuszone przez podłoże skalne. W tych odcinkach charakterystyczne są dobrze wykształcone kanały przepływów pozakorytowych (koryta przelewowe i powodziowe). Podczas wezbrań przekraczających stan pełnokorytowy, wody zalewają całą równinę zalewową (Kociuba 2002, Rodzik i in. 2008). W korytach małych rzek zachodniej i centralnej części pasa wyżyn istotne znaczenie dla przebiegu procesów fluwialnych miało przegradzanie koryt rzecznych i den dolin budowlami piętrzącymi typu jazy i groble oraz zbiornikami zaporowymi o funkcjach energetycznych (Ciupa 1991, Kociuba 2003, 2007, Rodzik i in. 2008), co często przyczyniać się może anastomozowaniu rzek (Ludwikowska-Kedzia 2001, Łajczak 2004). Koryta regulowane w XVIII i XIX w., wzmacniane faszyną (Pałys 1971), w których nie ponawiano prac hydrotechnicznych, podlegają renaturyzacji (Kociuba 2006) i stopniowo powracają do naturalnych parametrów geometrycznych jako koryta seminaturalne. Koryta skanalizowane na terenach zurbanizowanych, których parametry geometryczne utrwalone zostały przez wybetonowanie dna i brzegów pozostają współcześnie stabilne (Ciupa 2001).

Południową część Niżu Polskiego, pomiędzy granicą maksymalnego zasięgu zlodowacenia Wisły na północy, a Sudetami i pasem wyżyn na południu stanowi strefa staroglacjalna. Jej rzeźba ukształtowana została podczas starszych zlodowaceń, tj. odry i warty w czasie od ok. 255-260 000 do 20000 lat BP (Twardy, Klimek 2008). Obszar ten w okresie ostatniego zlodowacenia $\mathrm{w}$ ciągu kilkunastu tysięcy lat podlegał intensywnym przeobrażeniom peryglacjalnym, które wyraziły się m.in. zmianami układów sieci rzecznej (Turkowska 1975, 1988, 2006, Petera, Forysiak 2003, Petera 2008, Forysiak 2010). W obrębie tej strefy dominują rzeki autochtoniczne (Klimek 2008), których dorzecza leżą w jednorodnych przyrodniczo regionach, np. dorzecze Baryczy, Bzury, Narwi, Prosny i innych. Obok nich występują rzeki allochtoniczne, np. Bug, Pilica, Warta, Wieprz, których górne części dorzeczy usytuowane są $\mathrm{w}$ sąsiednich regionach. Jedynie lewobrzeżne dopływy Odry (m.in. Nysa Łużycka, Bóbr, Kaczawa, Nysa Kłodzka, Osłoboga) zostały zaliczone do typu przedgórskiego.

Dynamikę współczesnych procesów fluwialnych wyraża w tej strefie układ koryt oraz ich stabilność pozioma i wielkość ładunku dennego i zawieszonego (np. Kaniecki 1976, Młynarczyk, Rotnicki 1989). Dominują tu koryta kręte i meandrujące (Forysiak 2005, 2010, Ostrowski, Kaszyński 2014), natomiast w rozszerzeniach kotlin występują odcinki anastomozujące (np. Gradziński i in. 2000, 2003). Koryta roztokowe występują głównie $\mathrm{w}$ tranzytowej dolinie środkowej Wisły (Falkowski 2006) oraz w dolnych fragmentach niektórych jej dopływów (Kobojek 2009a, b, Weckwerth 2014). Wiele odcinków rzek, szczególnie $\mathrm{w}$ strefach osiedli lub $\mathrm{w}$ strefach $\mathrm{o}$ intensywnej gospodarce zostało obwałowanych, a ich naturalny przebieg znacząco zmieniony (Fajer 2018). 
Sieć rzeczna w obszarze młodoglacjalnym jest genetycznie związana $z$ warunkami geomorfologicznymi i hydrogeologicznymi pochodzącymi jeszcze z ostatniego okresu glacjalnego (Zwoliński i in. 2008). Poligenetyczność większości dolin (odcinki dawnych rynien glacjalnych, pradolinne, przełomowe, ukształtowane na szlakach sandrowych, odcinki obejmujące dawne formy wytopiskowe i odcinki w obrębie wysoczyzn morenowych) determinuje zróżnicowany układ współczesnych koryt, także w obrębie poszczególnych rzek (Rachocki 1974, Piasecki 1982, Zwoliński 1989, Florek 1991, 1997, Smolska 1996, Mazurek 1998). Koryta rzeczne oraz współczesne równiny zalewowe są tu w znacznej mierze odziedziczone po późnovistuliańskiej i holoceńskiej transformacji systemu fluwialnego (Augustowski 1977, Sylwestrzak 1978, Koutaniemi, Rachocki 1981, Piasecki 1982). Należy podkreślić, że złożony proces scalania postglacjalnych obniżeń i rozszerzeń w sieć dolinną i tworzenie się sieci rzecznej poprzez rozwój obszarów źródliskowych nie został zakończony na obszarach młodoglacjalnych (Mazurek 2006, 2010, Mazurek, Paluszkiewicz 2013). Współczesne procesy fluwialne w korytach oraz w obrębie równin zalewowych, obejmujące procesy erozji, transportu i akumulacji są zróżnicowane i wyrażają różne typy i tempo przemian koryt rzek oraz są efektem częstości występowania zdarzeń innych niż przeciętne, głównie wezbrań wiosennych i wczesno-letnich (Zwoliński 1985, Florek i in. 2008). Współczesna sieć rzeczna tej strefy obejmuje różne kierunki odwodnienia wynikające głównie z morfogenezy rzeźby Niżu Polskiego (Zwoliński i in. 2008). W efekcie można tu wyróżnić 5 głównych typów koryt: koryta południowego i północnego skłonu garbu pojeziernego, koryta proste lub kręte $\mathrm{w}$ obrębie równoleżnikowych dolin marginalnych lub pradolin oraz koryta w dolinach przełomowych o układzie południkowym lub zbliżonym, a także koryta dopływów dużych rzek tranzytowych (ryc. 14).

Koryta południowego skłonu garbu pojeziernego (Drawa, Gwda, Brda, Wda, Wieżyca, Drwęca, Skrwa, Biebrza) prowadzą wody w przybliżeniu południkowo $\mathrm{w}$ dnach dolin ukształtowanych najczęściej na szlakach sandrowych, zazwyczaj meandrujące na równinach zalewowych, niekiedy $z$ łańcuchem jezior przepływowych. Koryta północnego skłonu garbu pojeziernego (Ina, Rega, Parsęta, Grabowa, Wieprza, Słupia, Łupawa, Reda, Radunia, Pasłęka, Łyna) mają niewyrównane profile podłużne ( $w$ górnych biegach o prawie podgórskim charakterze o spadkach dochodzących nawet do 6,3\% (Kostrzewski i in. 1994)), najczęściej meandrujące i wykorzystujące na przemian a) odcinki przełomowe i wytopiskowe (o przebiegu mniej więcej południkowym) oraz b) fragmenty niewyraźnych dolin marginalnych lub pradolin (o przebiegu w przybliżeniu równoleżnikowym) (Zwoliński i in. 2008). Koryta tych rzek zostały ukształtowane w znacznym stopniu przez zmiany bazy erozyjnej Morza Bałtyckiego (Florek 1991, 1997). Koryta dopływów (Ina, Wierzyca, Drwęca) dużych rzek tranzytowych (np. Wisły i Odry) mają układ często odmienny w odcinkach wysoczyznowych (gdzie są one kręte) od fragmentów wyciętych $w$ terasach dolin głównych (meandrujące $\mathrm{w}$ obrębie szerokich równin zalewowych) (Andrzejewski 1994a, Błaszkiewicz 1998, 2005).

Obserwowany wzrost częstości ekstremalnych zdarzeń meteorologicznych, hydrologicznych i geomorfologicznych powoduje, że kształtowanie den dolinnych we wszystkich strefach morfogenetycznych jest współcześnie coraz intensywniejsze (Zwoliński 2008, Jania, Zwoliński 2011, Zwoliński 2011). Polega ono nie tylko na zmianach planarnych układów koryt rzecznych powodowanych przepływami wezbraniowymi, np. środkowa Wisła (Łajczak i in. 2006) czy wiele rzek górskich i wyżynnych, ale przede wszystkim na zmianach pionowych, a więc:

- wcinaniu się w podłoże tak jak w przypadku głównie rzek górskich (Klimek 1983, 1987, Krzemień 2003, Starkel, Łajczak 2008, Wyżga 2008, Wyżga $\mathrm{i}$ in. 2010, Zawiejska, Wyżga 2010, Zawiejska i in. 2015, Gorczyca i in. 2017) lub

- intensywnym przerabianiu aluwiów korytowych rzek wyżynnych i nizinnych (Rachocki 1974, Zwoliński 1989, Ciupa 1991, Rodzik i in. 2008, Michno 2013) lub

- na nadbudowywaniu teras zalewowych głównie rzek nizinnych, ale także rzek górskich i wyżynnych (Gonera i in. 1985, Teisseyre 1985, Zwoliński 1985, 1992, Kalicki 1991, 2006, Gębica 1995, Łajczak 1995, Gębica, Sokołowski 1999, 2001, Czajka 2000, 2007, Kukulak 2004, Kaczmarzyk $\mathrm{i}$ in. 2008, Rodzik i in. 2008, Falkowski, Ostrowski 2010, Szmańda 2011, Michno 2013, Kordowski i in. 2014, Ostrowski, Kaszyński 2014, Skolasińska i in. 2015, Ostrowski, Falkowski 2016), niekiedy również na skutek przerywania wałów przeciwpowodziowych (Gębica i in. 1998, Gębica, Sokołowski 2001, Bujakowski, Falkowski 2017, Wierzbicki i in. 2018).

Dynamicznie zmieniające się przebiegi procesów erozyjnych i akumulacyjnych na terasach zalewowych przyczyniają się do częstych zmian morfologicznych $w$ ich obrębie, dochodzących niekiedy od $-2 \mathrm{~m}$ do $+1 \mathrm{~m}$, co znacznie utrudnia prognozowanie ryzyka powodziowego (Kundzewicz 2012), szczególnie na obszarach zurbanizowanych czy zagospodarowanych (Łajczak 2006a, b, Lechowska 2017), m.in. w obrębie polderów (Warachowska i in., w druku). Sedymentacja piaszczystych i mułkowych osadów pozakorytowych w zagłębieniach terasowych (basenach powodziowych) coraz częściej dominuje wśród procesów fluwialnych $\mathrm{w}$ dnach dolinnych rzek wyżynnych i nizinnych, co przy narastającym oddziały- 
waniu człowieka na dna dolin przyczynia się do coraz częstszych zmian typów pokrycia terenu i użytkowania ziemi na równinach zalewowych (Kociuba 2003, 2006a, Kukulak 2004, Kupiec 2014, Borowska-Stefańska 2017).

Koryta rzek polskich na wielu odcinkach są uregulowane przy pomocy budowli hydrotechnicznych położonych podłużnie i/lub poprzecznie względem koryta, a koryta dużych rzek są dodatkowo obwałowane. Na skutek ingerencji człowieka w ostatnich (50.-70.) latach nastąpił wyraźny i znaczący wzrost erozji wgłębnej w korytach rzek karpackich i na ich przedpolu. Materiał klastyczny wynoszony z tych koryt współcześnie jest deponowany na międzywalu Wisły, szczególnie w Kotlinie Sandomierskiej w rejonie Sandomierza (Gębica i in. 1998, Gębica, Łajczak 1999, Gębica 2004). Istotne zmiany w układach koryt rzecznych a tym samym zmiany w wyrazie morfologicznym i sedymentologicznym den dolinnych są efektem budowy młynów wodnych, różnego rodzaju tam i zapór wodnych, węzłów i dróg komunikacyjnych, jak również wybetonowania i obwałowywania koryt rzecznych. W tym pierwszym przypadku, tj. młynów wodnych, których występowanie kształtowało dna dolin rzecznych należy zwrócić uwagę, że związane $z$ ich istnieniem prace regulacyjne trwały bardzo długo, bowiem praktycznie od średniowiecza aż po wiek XX (Kaniecki 1999, Brykała 2001, 2005, Podgórski 2001, 2004, 2009, Kukulak 2004, Korpak $\mathrm{i}$ in. 2008, Kobojek 2009a, b, Kaniecki, Brychcy 2010, Korpak 2010, Kaniecki i in. 2012, Witek 2012, Kaniecki 2013, Krupa 2013, Twardy 2013, Witkowski, Wysmołek 2015, Gorczyca 2016, Brykała i in. 2017, Witkowski, Witkowski 2017, Fajer 2018a, Zwoliński i in. 2018). Wpływ tam i zapór na morfologię den dolinnych ilustrowany przede wszystkim procesami erozyjnymi poniżej tych budowli był wielokrotnie dokumentowany w opracowaniach geomorfologicznych (m.in. Babiński 1982, 1992, 1997, 2002, Froehlich 1990, Banach 1994, Wierzbicki i in. 2008, Babiński, Habel 2009, Korpak 2010, Witek 2012, Banach i in. 2013, Gierszewski i in. 2015, Kaczmarek 2018), ale również ważna kwestią pozostają wypełniania osadami czasz zbiorników i rozwoju systemów korytowych w tych odcinkach dolin (Froehlich, Klimek 1979, Łajczak 2006c, Grobelska 2008, Kaczmarek 2010, Jaskulski, Szmidt 2014, Liro 2017, Gierszewski 2018).

$\mathrm{Na}$ wielu odcinkach koryt naturalnych jak i uprzednio uregulowanych, na skutek braku lub zmniejszającej się antropopresji, np. zanik młynów wodnych (Kaniecki 1999, Podgórski 2004, 2009, Kaniecki, Brychcy 2010, Brykała i in. 2017, Witkowski, Witkowski 2017, Fajer 2018b) czy regres osadniczy, odłogowanie pól uprawnych, sukcesje zbiorowisk leśnych w dolinach (Eberhardt 1989, Kukulak 2003, 2004, Latocha 2007, 2013, Wolski 2007) następuje spontaniczna renaturyzacja rzek (Żelazo, Popek
2002, Kociuba 2006, Żelazo 2006, Wyżga i in. 2008, Gorczyca 2016). Proces ten jest przyspieszany także dzięki aktywności bobrów (Stopka 2011, Kobojek 2013, Rurek i in. 2013, 2016, Grygoruk, Nowak 2014, Giriat i in. 2016, Fajer i in. 2017, Pawlaczyk 2017, Gorczyca i in. 2018, Szpikowski, Szpikowska 2018) oraz coraz szerszemu zrozumieniu potrzeby ochrony rzek (Pawlaczyk 2017).

\section{Uwagi końcowe}

Zróżnicowanie systemów dolinnych i korytowych w Polsce w różnym stopniu uwarunkowane jest czynnikami regionalnymi i lokalnymi, wyrażającymi się przemiennością stref morfotektonicznych i morfogenetycznych, ale także oddziaływań klimatycznych i hydrologicznych. Niezależnie od zróżnicowania ewolucyjnego poszczególnych odcinków dolin, systemy fluwialne w skali dorzeczy funkcjonują jako złożone, połączone ze sobą struktury obiegu wody i osadów. Koryta rzek obszaru Polski nawiązują wyraźnie do rzeźby odziedziczonej z przeszłości (Starkel 2005, 2008, 2017). Zasadnicze ich zróżnicowanie nawiązuje do równoleżnikowego układu hipsometrycznego i morfogenetycznego kraju.

Rzeki obszarów górskich i wyżynnych podlegają obecnie zarówno silnemu oddziaływaniu ekstremalnych zjawisk przyrodniczych, jak i wyjątkowo aktywnej działalności człowieka na jednych obszarach, szczególnie miejskich, podczas gdy na innych obszarach podlegają stosunkowo szybkiej renaturyzacji, głównie na obszarach opuszczonych przez ludzi. Te silne impulsy antropogeniczne na systemy stokowo-rzeczne powodują wyraźne przeobrażenia w dotychczasowym funkcjonowaniu tych systemów (Klimek 1987, Kostrzewski i in. 1994, Klimek, Latocha 2007, Latocha 2007, Gębica 2013, Michno 2013). Wzrost intensywności procesów erozyjnych, transportowych i akumulacyjnych w dolinach rzecznych przyczynia się do zmian układów koryt rzecznych, zmian geometrii koryt, zmian tempa migracji bocznej, a w konsekwencji wpływa na zmiany zarządzania i gospodarowania obszarami dolinnymi.

W strefie staroglacjalnej stabilność tektoniczna podłoża oraz zróżnicowanie litologiczne pokryw czwartorzędowych spowodowały, że profile podłużne den dolin w relatywnie długim czasie dostosowały się do lokalnych i regionalnych baz erozyjnych. Rzeki tej strefy rozcinają przeważnie luźne utwory czwartorzędowe, co powoduje, że współczesne koryta aluwialne są głównie typu piaskodennego lub rzadziej żwirodennego, zarówno o tendencjach agradacyjnych jak i degradacyjnych. Porównując zróżnicowanie współczesnych systemów korytowych w tej strefie, pomimo ich zróżnicowanych układów, tj. o rozwinię- 
ciu krętym, meandrowym, czy nawet lokalnie anastomozującym i roztokowym, do obszaru młodoglacjalnego oraz obszaru gór i wyżyn można stwierdzić, że jest ono względnie najmniejsze.

W dnach dolin strefy młodoglacjalnej, podobnie jak w obszarach górskich i wyżynnych obserwuje się zjawisko nakładania się dwóch przeciwstawnych tendencji, a mianowicie coraz głębszego przerabiania aluwiów korytowych, głównie w czasie wysokich przepływów i nadbudowywania równin zalewowych osadami pozakorytowymi. W dnach dolin o małych spadkach (pradolinach, dolinach marginalnych) zachodzą głównie procesy sedymentacji pokryw powodziowych, w tym sedentacja złóż torfu. W korytach rzek przepływających przez równiny biogeniczne, głównie torfowe, wypełniające zróżnicowane zagłębienia (rynny polodowcowe, zagłębienia wytopiskowe) zachodzi zjawisko stopniowej wymiany utworów biogennych na aluwia rzeczne.

Wiedza o złożonych uwarunkowaniach przyrodniczo-antropogenicznych kształtujących dawne i współczesne systemy fluwialne ma podstawowe znaczenie dla prognozowania ich zmian $\mathrm{w}$ przyszłości. Zagadnienia te $\mathrm{w}$ kontekście obserwowanych zmian klimatycznych i narastającej antropopresji nabierają szczególnej roli. Obserwowane przemiany w polskich systemach fluwialnych wskazują jak bardzo wrażliwe są koryta rzeczne na globalne, regionalne i lokalne zmiany klimatu oraz zmiany użytkowania ziemi. Systemowe ujęcie problematyki ewolucji dolin i współczesnych zmian w korytach rzek powinno być podstawą dla właściwego zarządzania ryzykiem powodziowym z jednej strony, a $z$ drugiej dla coraz powszechniej wdrażanej koncepcji rewitalizacji i renaturyzacji szlaków wodnych.

Analiza stanu wiedzy na temat ewolucji i wspólczesnych uwarunkowań funkcjonowania systemów dolinnych i korytowych na obszarze Polski wskazuje na zasadność dalszych skoordynowanych pomiędzy ośrodkami geomorfologicznymi badań, idących w kierunku kompleksowych ujęć geoekosystemów fluwialnych. Zatem istnieje pilna potrzeba wypracowania uniwersalnych kryteriów klasyfikacji dolin i współczesnych układów korytowych w skali całego kraju opartych na parametrach ilościowych, uwzględniających np. m.in. spadek koryta, współczynnik krętości, stosunek szerokości do głębokości koryta, rodzaj transportowanego materiału itp. Współpraca w tym zakresie została już ostatnio zainicjowana, a dotyczy m.in. próby określenia tendencji agradacyjnych i degradacyjnych $w$ dnach koryt i dolin w skali całej Polski (Andrzejewski i in. 2018).

\section{Podziękowania}

Autorzy dziękują siedmiu recenzentom za wnikliwe uwagi do pierwotnej wersji artykułu.

\section{Wkład autorów}

Leon Andrzejewski: 1/3, Kazimierz Krzemień: 1/3, Zbigniew Zwoliński: $1 / 3$.

\section{Literatura}

Alexandrowicz S.W., Klimek K., Kowalkowski A., Mamakowa K., Niedziałkowska E., Pazdur M., Starkel L., 1981. The evolution of the Wisłoka valley near Dębica Poland during the Late Glacial and Holocene. Folia Quaternaria 53: 1-91.

Andrzejewski L., 1991. The course of fluvial processes in the Lower Bzura River Valley turing the last 15000 years. Geographical Studies, Special Issue 6: 147-154.

Andrzejewski L., 1994a. Ewolucja system fluwialnego doliny dolnej Wisły w późnym vistulianie i holocenie na podstawie wybranych dolin jej dopływów. Rozprawy UMK, Toruń.

Andrzejewski L., 1994b. Paleohydrologiczna interpretacja zmian geometrii paleokoryt wybranych dopływów dolnej Wisły. Acta Universitatis Nicolai Copernici, Geografia XXVII(98): 121-129.

Andrzejewski L., Florek W., Krzemień K., Smolska E., Zwoliński Zb., 2018. Wieloterminowe tendencje degradacyjne i agradacyjne polskich koryt i dolin rzecznych. W: Antropogeniczne uwarunkowania współczesnych procesów fluwialnych. Instytutu Geografii i Gospodarki Przestrzennej, Kraków-Rabka-Zdrój: 130-131.

Andrzejewski L., Krzemień K., 2017. Doliny i koryta rzek. W: Hydrologia Polski, P.Jokiel, J.Pociask-Karteczka, W.Marszalewski (red.), PWN, Warszawa: 121-127.

Andrzejewski L., Starkel L., 2017. Ewolucja systemów dolinnych i zmiany w obiegu wody od ustąpienia ostatniego zlodowacenia. W: Hydrologia Polski, P.Jokiel, J.Pociask-Karteczka, W.Marszalewski (red.), PWN, Warszawa: 111-116.

Antczak B., 1986. Transformacja układu koryta i zanik bifurkacji Warty w Pradolinie Warszawsko-Berlińskiej i południowej części przełomu poznańskiego podczas vistulianu. Wydawnictwo Naukowe UAM, Geografia 35.

Augustowski B., 1977. Pomorze. PWN, Warszawa.

Babiński Z., 1982. Procesy korytowe Wisły poniżej zapory wodnej we Włocławku. Dokumentacja Geograficzna 1-2.

Babiński Z., 1992. Współczesne procesy korytowe dolnej Wisły. Prace Geograficzne IGPZ PAN 157.

Babiński Z., 1997. Procesy erozyjno-akumulacyjne poniżej stopnia wodnego Włocławek, ich konsekwencje i wpływ na morfodynamikę planowanego zbiornika Nieszawa. Instytut Geografii i Przestrzennego Zagospodarowania, Polska Akademia Nauk, Torun.

Babiński Z., 2002. Wpływ zapór na procesy korytowe rzek aluwialnych ze szczególnym uwzględnieniem stopnia wodnego „Włocławek". Wydawnictwo AB, Bydgoszcz.

Babiński Z., Habel M., 2009. Dynamika strefy akumulacyjnej poniżej czoła odcinak o wymuszonej erozji wgłębnej Zbiornika Włocławskiego. W: A.T.Jankowski, D.Absalon, R.Machowski, M.Ruman (red.), Przeobrażenia stosunków wodnych w warunkach zmieniającego się środowiska. Wydział nauk o Ziemi UŚ, Sosnowiec: $35-43$.

Bajkiewicz-Grabowska E., 2002. Obieg materii w systemach rzeczno-jeziornych. Wydawnictwo Uniwersytetu Warszawskiego, Warszawa: 1-274.

Bala E., 2018. Dynamika holoceńskich procesów fluwialnych w świetle badań sedymentologicznych na przykładzie Liwca. MS. Uniwersytet Warszawski, Wydział Geografii i Studiów Regionalnych, Warszawa.

Banach M., 1994. Morfodynamika strefy brzegowej zbiornika Włocławek. Prace Geograficzne IGiPZ PAN 161.

Banach M., Kaczmarek H., Tyszkowski S., 2013. Rozwój osuwisk w strefie brzegowej sztucznych zbiorników wodnych na przykładzie osuwiska centralnego w Dobrzyniu nad Wisłą, zbiornik włocławski. Przegląd Geograficzny 85(3): 397-415. 
Banaszuk H., Micun K., Banaszuk P., 2016. Budowa geologiczna i rzeźba terenu. W: P.Banaszuk, D.Wołkowycki (red.), Narwiański Park Narodowy - Krajobraz, przyroda, człowiek, Narwiański Park Narodowy, Białystok-Kurowo.

Błaszkiewicz M., 1998. Dolina Wierzycy, jej geneza oraz rozwój w późnym plejstocenie i wczesnym holocenie. Dokumentacja Geograficzna 10.

Błaszkiewicz M., 2005. Późnoglacjalna i wczesnoholoceńska ewolucja obniżeń jeziornych na Pojezierzu Kociewskim (wschodnia część Pomorza). Prace Geograficzne IGPZ PAN, 201.

Blum M.D., Womack J.H., 2009. Climate change, sea-level change, and fluvial sediment supply to deepwater systems. In: B.Kneller, O.J.Martinsen, B.McCaffrey (eds), External Controls on Deep Water Depositional Systems: Climate, Sea-Level, and Sediment Flux, SEPM Special Publication 92: 15-39.

Borowska-Stefańska M., 2017. Zagospodarowanie terenów zagrożonych powodziami w gminach województwa łódzkiego. Przegląd Geograficzny 87(3): 535-553.

Brykała D., Prarat M., Lamparski P. (red.), 2017. Młyny wodne w dorzeczu dolnej Wisły od początku XVIII do początku XXI wieku. Interdyscyplinarne Seminarium Naukowe, IGiPZ PAN, UMK, Toruń: 1-58.

Brzezińska-Wójcik T., Kociuba W., 2001. Transformacja roztoczańskiego odcinka doliny Wieprza w plejstocenie, Przegląd Geologiczny 49 (3): 257-266.

Bucała A. 2012. Współczesne zmiany środowiska przyrodniczego pod wpływem działalności człowieka w dolinach potoków Jaszcze i Jamne (Gorce). Landform Analysis 19: 5-15.

Bujakowski F., Falkowski T., 2017. Wykorzystanie lotniczego skaningu laserowego do oceny warunków przepływu wód w osadach równi zalewowej. Przegląd Geologiczny 65(7): 443-449.

Castelltort S., Van Den Driessche J., 2003. How plausible are highfrequency sediment supply-driven cycles in the stratigraphic record? Sedimentary Geology 157(1-2): 3-13.

Chmal H., 2002. Stanowisko mady w Kamieńcu Ząbkowickim. W: A.Traczyk, A.Latocha (red.), Srodowiska górskie - ewolucja rzeźby, VI Zjazd Geomorfologów Polskich, Jelenia Góra, Streszczenia referatów i posterów: $25-26$

Ciszewski D., Dubicki A, 2008. Reżim hydrologiczny i współczesne przemiany koryta i równiny zalewowej Odry. W: L.Starkel, A.Kostrzewski, A.Kotarba, K.Krzemień (red.), Współczesne przemiany rzeźby Polski, Wydawnictwo IGiGP UJ, Kraków: 371-383.

Ciupa T., 1991. Współczesny transport fluwialny w zlewni Białej Nidy. WSP, Kielce: 1-150.

Ciupa T., 2001. Funkcjonowanie koryt rzecznych Silnicy i Sufragańca w strefie miejskiej Kielc. W: A.Karczewski, Zb.Zwoliński (red.), Funkcjonowanie geoekosystemów w zróżnicowanych warunkach morfoklimatycznych. Monitoring, ochrona, edukacja. Stowarzyszenie Geomorfologów Polskich, Bogucki Wydawnictwo Naukowe, Poznań: 103-113.

Czaja S., Degórska V., Leśniok M., 1993: Naturalne i antropogeniczne zmiany koryta Wisły od zbiornika w Goczałkowicach do ujścia Przemszy. Geographia. Studia et dissertationes UŚ 17: $7-15$.

Czajka A., 2000. Sedymentacja pozakorytowa aluwiów w strefie międzywala Wisły w Kotlinie Oświęcimskiej. Przegląd Geologiczny 48(3): 263-267.

Czajka A., 2007. Środowisko sedymentacji osadów przykorytowych rzek uregulowanych na przykładzie górnej Odry i górnej Wisły. Prace Naukowe Uniwersytetu Śląskiego w Katowicach 2534.

Drwal J., 1985. Jeziora w egzoreicznych systemach pojezierzy młodoglacjalnych. Zeszyty Naukowe Uniwersytetu Gdańskiego, Geografia 14: 7-15.

Dobrowolski R., Pidek I.A., Gołub S., Dzieńkowski T., 2010. Environmental changes and human impact on Holocene evolution of the Horodyska River valley (Lublin Upland, East Poland). Geochronometria 35: 35-47.

Eberhardt P., 1989. Regiony wyludniające się w Polsce. Prace Geograficzne IGiPZ PAN 148.
Fajer M., 2004. Morfologiczne i geologiczne uwarunkowania rozwoju doliny Liswarty w holocenie. Prace Wydziału Nauk o Ziemi Uniwersytetu Śląskiego 32: 1-108.

Fajer M., 2018a. Antropogenicznie uwarunkowane przełomy Suminy i Wierzbnika jako przykład naturalizacji sztucznych koryt rzecznych (zlewnia Rudy). Prace Geograficzne 153: 7-24.

Fajer M., 2018b. Changes in river channel pattern as a result of the construction, operation and decommissioning of watermills - the case of the middle reach of the River Liswarta near Krzepice, Poland. Environmental \& Socio-economic Studies 6(1): 25-37.

Fajer M., Malik I., Waga J.M., Wistuba M., Woskowicz-Ślęzak B., 2017. Współczesne wykorzystanie przez bobra europejskiego Castor fiber antropogenicznie przekształconych dolin rzecznych (przykłady z Równiny Opolskiej i Wyżyny Woźnicko-Wieluńskiej). Przegląd Geograficzny 89(3): 467-489.

Falkowski E., 1975. Variability of channel processes of lowland rivers In Poland and changes of the valley floors during the Holocene. Biuletyn Geologiczny UW 19: 45-78.

Falkowski E., 1990. Morphogenetic classification of river valleys developing in formerly glaciated areas for needs of mathematical and physical modeling in hydro technical projects. Geographia Polonica 58: 55-67.

Falkowski T., 2006. Naturalne czynniki stabilizujące wybrane odcinki strefy korytowej Wisły środkowej. Rozprawy Naukowe i Monografie SGGW, Warszawa: 1-128.

Falkowski T., 2015. Analiza geologicznych uwarunkowań kształtowania się różnorodności siedliskowej dolin rzecznych na Niżu Polskim. Przegląd Naukowy - Inżynieria i Kształtowanie Środowiska 70: 342-349.

Falkowski T., Ostrowski P., 2010. Morfogeneza powierzchni tarasu zalewowego Wisły w okolicach Magnuszewa w obrazie zdjęć satelitarnych i lotniczych. Infrastruktura i Ekologia Terenów Wiejskich 9: 89-100.

Florek E., Florek W., Mycielska-Dowgiałło E., 1987. Morphogenesis of the Vistula Valley between Kępa Polska and Plock In the Late Glacial and Holocene. W: L.Starkel (red.), Evolution of the Vistula river valley during the last 15000 years. Part 2. Geographical Studies, Special Issue 4: 189-205.

Florek W., 1982. Development of the lower Bóbr valley floor, with emphasis on the Late Holocene. Quaestiones Geographicae 8 : 91-119.

Florek W., 1991. Postglacjalny rozwój dolin rzek środkowej części północnego skłonu Pomorza. Prace Wyższej Szkoły Pedagogicznej 174 .

Florek W., 1997. Climatic and anthropogenic impulses in the Late Vistulian and Holocene development of the river channels and valleys of the Baltic Coastal Region and Pomerania. Landfonn Analysis 1: 41-50.

Florek W., Rudowski S., Szefler K., 2010. Palaeo-valleys in the region of the Słupia River mouth. Quaestiones Geographicae 29(3): 27-36.

Florek W., Zwoliński Zb., Andrzejewski L., Kostrzewski A., Smolska E., Szmańda J., 2008. Współczesne procesy kształtujące rzeźbe dolin rzecznych. W: L.Starkel, A.Kostrzewski, A.Kotarba, K.Krzemień (red.), Współczesne przemiany rzeźby Polski, Wydawnictwo IGiGP UJ, Kraków: 292-305.

Forysiak J., 2005. Rozwój doliny Warty między Burzeninem i Dobrowem po zlodowaceniu Warty. Acta Geographica Lodziensia 90.

Forysiak J., 2010. Zastosowanie analizy zdjęć lotniczych do rekonstrukcji układu wielokorytowego środkowej Warty. Landform Analysis 13: 13-18.

Froehlich W., 1975. Dynamika transportu fluwialnego Kamienicy Nawojowskiej. Prace Geografczne IGiPZ PAN 114.

Froehlich W., 1982. Mechanizm transportu fluwialnego i dostawy zwietrzelin do koryta w górskiej zlewni fliszowej. Prace Geografczne IGiPZ PAN 143.

Froehlich W., 1990. Racjonalna zabudowa koryt potoków pod kątem zabezpieczenia przeciw powodziowego i przeciwerozyjnego. Problemy Zagospodarowania Ziem Górskich 30: 49-69. 
Froehlich W., Klimek K., 1979. Debris sedimentation in overfllwoing mountain streamlets upstream drop dams. Excursion Guide-book, Field Meeting of the IGU Commission on Field Experiments in Geomorphology, Poland: 135-141.

Galon R., 1953. Morfologia doliny i sandru Brdy. Studia Societatis Scientiarum Torunensis, ser. C 1(6): 1-55.

Galon R., 1968. Ewolucja sieci rzecznej na przedpolu zanikającego lądolodu. Prace Geograficzne IG PAN 74: 101-120.

Gębica P., 1995. Ewolucja doliny Wisły pomiędzy Nowym Brzeskiem a Opatowcem w vistulianie i holocenie. Dokumentacja Geograficzna 2: 1-89.

Gębica P., 2004. Przebieg akumulacji rzecznej w górnym vistulianie w Kotlinie Sandomierskiej. Prace Geograficzne IGiPZ PAN 193: 1-229.

Gębica P., 2011. Stratigraphy of alluvial fills and phases of the Holocene floods in the lower Wisłok River valley, SE Poland. Geographia Polonica 84(1): 39-60.

Gębica P., 2013. Geomorphological records of human activity reflected in fluvial sediments in the Carpathians and their foreland. Landform Analysis 22: 21-31.

Gębica P., Patkowski B., Lasek A., Sokołowski T., 1998. Geomorfologiczne i sedymentologiczne skutki przerwania wałów przeciwpowodziowych w dolinie Wisły w lipcu 1997 roku. W: L.Starkel, J.Grela (red.), Powódź w dorzeczu górnej Wisły w lipcu 1997 roku, Wydawnictwo Oddziału PAN, Kraków: 185-194.

Gębica P., Sokołowski T., 1999. Catastrophic geomorphic processes and sedimentation in the Vistula Valley between the Dunajec and Wisłoka mouths during the 1997 flood, southern Poland. Quaternary Studies in Poland, Spec. Issue: 253-261.

Gębica P., Sokołowski T., 2001. Sedimentological interpretation of crevasse splays formed during extreme 1997 flood in the upper Vistula river valley (South Poland). Annales Societatis Geologorum Poloniae 71: 53-62.

Gierszewski P., 2018. Hydromorfologiczne uwarunkowania funkcjonowania geoekosystemu Zbiornika Włocławskiego. Prace Geograficzne IGiPZ PAN 268: 7-223.

Gierszewski P.J., Szmańda J.B., Luc M., 2015. Zmiany układu koryt Wisły spowodowane funkcjonowaniem stopnia wodnego „Włocławek" na podstawie analizy zdjęć lotniczych. Przegląd Geograficzny 87(3): 517-533.

Gilewska S., 1991. Rzeźba. W: L.Starkel (red.), Geografia Polski. Środowisko przyrodnicze, Wydawnictwo Naukowe PWN, Warszawa: $243-288$.

Giriat D., Gorczyca E., Sobucki M., 2016. Beaver ponds' impact on fluvial processes (Beskid Niski Mts., SE Poland). Science of the Total Environment 544: 339-353.

Gonera P., 1986. Zmiany geometrii koryt meandrowych Warty na tle wahań klimatycznych w późnym vistulianie i holocenie. Wydawnictwo Naukowe UAM, Geografia 33.

Gonera P., Kijowski A., Zwoliński Zb., 1985. Powezbraniowe formy akumulacyjne na terasie zalewowej Warty i Parsęty w świetle analizy zdjęć lotniczych. Fotointerpretacja w geografii 8(18): 24-42.

Gorajska J., 2014. Wpływ regulacji technicznej na równowagę pionową koryta Wisły na przedpolu Karpat. Landform Analysis 26: 3-9.

Gorczyca E., 2016. Rozwój górskich żwirodennych koryt rzecznych w warunkach antropopresji. IGiGP UJ, Kraków.

Gorczyca E., Krzemień K., Liro M., Sobucki M., 2017. Changes of mountain river channels and their environmental effects. W: A.Radecki-Pawlik, J.Hradecky, S.Pagliara, E.Hendrickson (eds), Open channel hydraulics, River hydraulics structures and fluvial geomorphology: for engineers, geomorphologists and physical geographers, Science Publishers, CRC Press, Taylor\&Francis Group: 303-321.

Gorczyca E., Krzemień K., Sobucki M., Jarzyna K. 2018. Can beaver impact promote river renaturalization? The example of the Raba River, southern Poland. Science of the Total Environment 615: 1048-1060.

Grabowski T., Harasiumiuk A., Gerlée A., 2018. Doliny rzeczne kłopot regionalizacji fizycznogeograficznej. Prace i Studia Geograficzne 63(1): 37-44.
Gradziński R., Baryła J., Doktor M., Gmur D., Gradziński M., Kędzior A., Paszkowski M., Soja R., Zieliński T., Żurek S., 2003. In-channel accretionary macroforms in the modern anastomosing system of the upper Narew River, NE Poland. Annales Societatis Geologorum Poloniae 73: 35-53.

Gradziński R., Baryła J., Dynowski W., Doktor M., Gmur D., Gradziński M., Kędzior A., Paszkowski M., Soja R., Zieliński T., Żurek S., 2000. Anastomosing system of the Upper Narew River, NE Poland. Annales Societatis Geologorum Polonaiae 70: 217-229.

Grobelska H., 2008. Above-water accumulative forms within the shore zone of the reservoir showing significant seasonal water level fluctuations based on the Pakoski reservoir. Landform Analysis 6: 28-40.

Grygoruk M., Nowak M., 2014. Spatial and Temporal Variability of Channel Retention in a Lowland Temperate Forest Stream Settled by European Beaver (Castor fiber). Forests 5: 2276-2288.

Harasimiuk M., 1991. Vistulian glacial cycle of the fluvial processes development in the valley of the middle Wieprz river (SE Poland). Annales Universitatis Mariae Curie-Skłodowska, Sectio B 46(5): 81-109.

Jania J., Zwoliński Zb., 2011. Ekstremalne zdarzenia meteorologiczne, hydrologiczne i geomorfologiczne w Polsce. Landform Analysis 15: 51-64.

Jaskulski M., Szmidt A., 2014. Transformations in morphometry of valley bottom as a result of the creation of a reservoir illustrated with the example of Sulejów Lake. Landform Analysis 24: 27-33.

Jaworski T., 2005. Morfogeneza rynny Welskiej (Pojezierze Chełmińsko-Dobrzyńskie) w okresie glacjalnym. Acta Universitatis Nicolai Copernici, Geografia XXXIII(111): 61-81.

Jokiel P., Marszelewski W., Pociask-Karteczka J. (red.), 2017. Hydrologia Polski. Wydawnictwo Naukowe PWN, Warszawa.

Kaczmarek H., 2010. Analiza zdjęć lotniczych oraz wyników pomiarów geodezyjnych w badaniach dynamiki strefy brzegowej sztucznych zbiorników wodnych - zbiornik Jeziorsko, rzeka Warta. Landform Analysis 13: 19-26.

Kaczmarek H., 2018. Ewolucja strefy brzegowej nizinnych zbiorników zaporowych w warunkach dużych wahań poziomu wody na przykładzie Zbiornika Jeziorsko na Warcie. Prace Geograficzne IGiPZ PAN 265.

Kaczmarzyk J., Florek W., Olszak I.J., 2008. Górnoholoceńskie i współczesne formy i osady pozakorytowe w dolinie środkowej Wieprzy. Landform Analysis 7: 80-94.

Kalicki T., 1991. The evolution of the Vistula river valley between Cracow and Niepołomice in Late Vistulian and Holocene times. W: L.Starkel (red.), Evolution of the Vistula river valley during the last 15000 years, part IV, Geographical Studies, Special Issue $6: 11-37$.

Kalicki T., 2006. Zapis zmian klimatu oraz działalności człowieka i ich rola w holoceńskiej ewolucji dolin środkowoeuropejskich. Prace Geograficzne 204.

Kalicki T., Krąpiec M., 1994. Problemy datowań form aluwialnych za pomocą metody dendrochronologicznej na przykładzie doliny Wisły koła Krakowa. Geochronometria 10: 173-189.

Kalicki T., Krapiec M., 1995. Problems of dating alluvium using buried subfossil tree trunks: lessons from the „black oaks" of the Vistula Valley, Central Europe. The Holocene 5(2): 243-250.

Kalicki T., Starkel L., Sala J., Soja R., Zernickaya V.P., 1996. Subboreal paleochannel system in the Vistula valley near Zabierzów Bocheński (Sandomierz Basin). W: L. Starkel (red.), Evolution of the Vistula river valley during the last 15000 years, Pt. VI. Geographical Studies, Special Issue 9: 129-158.

Kamykowska M., Kaszowski L., Krzemień K., 2012. Kartowanie koryt rzecznych. W: K.Krzemień (red), Struktura koryt rzek i potoków (studium metodyczne). IGiGP UJ, Kraków: 1-144.

Kaniecki A., 1976. Dynamika rzeki w świetle osadów trzech wybranych odcinków Prosny. Prace Komisji Geograficzno-Geologicznej PTPN 17.z

Kaniecki A., 1999. Młyny wodne w dawnym Poznaniu i ich wpływ na przeobrażenie stosunków wodnych. Acta Universitatis Nicolai Copernici, Geografia 29: 337-346. 
Kaniecki A., 2013. Wpływ antropopresji na przemiany środowiskowe w dolinie Warty w Poznaniu. Landform Analysis 24: 23-34.

Kaniecki A., Brychcy D., 2010. Średniowieczne młyny wodne i ich wpływ na przemiany stosunków wodnych na przykładzie zlewni Obry Skwierzyńskiej. Badania Fizjograficzne Seria A - Geografia Fizyczna 61: 145-156.

Kasprzak M., 2008. Strefy erozji i akumulacji podczas fluwialnych zdarzeń ekstremalnych w Sudetach, przykład Wilczej Poręby w Karpaczu. Landform Analysis 8: 36-40.

Kaszowski L., Krzemień K., 1977. Structure of mountain channel systems as exemplified by chosen Carpathians streams. Studia Geomorphologica Carpatho-Balcanica 11: 111-125.

Kaszowski L., Krzemień K., 1986. Metody typologii koryt rzecznych. Zeszyty Naukowe UJ, Prace Geograficzne 67: 7-23.

Kaszowski L., Krzemień K.,1999. Classification systems of mountain river channels. W: K.Krzemień (red.), River channels pattern, structure and dynamics, Prace Geograficzne Instytutu Geografii UJ 104: 27-40.

Kaszowski L., Niemirowski M., Trafas K., 1976. Problems of the dynamics of river channels in the Carpathian part of the Vistula basin. Zeszyty Naukowe UJ, Prace Geograficzne 43: 7-37.

Klimek K., 1983. Erozja wgłębna dopływów Wisły na przedpolu Karpat. W: Z.Kajak (red.), Ekologiczne podstawy zagospodarowania Wisły i jej dorzecza. PWN, Warszawa-Łódź: 97-108.

Klimek K., 1987. Mans's impact on fluvial processes in the Polish Western Carpathians. Geografiska Annaler 69A: 221-226.

Klimek K., 1991. Typy koryt rzecznych i ich funkcjonowanie. W: I.Dynowska, M.Maciejewski (red.), Dorzecze górnej Wisły, cz. I, PWN, Warszawa-Kraków: 231-259.

Klimek K., 2008. Współczesne procesy rzeczne w strefie staroglacjalnej. W: L.Starkel, A.Kostrzewski, A.Kotarba, K.Krzemień (red.), Współczesne przemiany rzeźby Polski, Wydawnictwo IGiGP UJ, Kraków: 236-239.

Klimek K., Latocha A., 2007. Response of small mid-mountain rivers to human impact with particular reference to the last 200 years; Eastern Sudetes, Central Europe. Geomorphology 92(34): 147-165.

Klimek K., Starkel L., 1974. History and actual tendency of flood-plain development at the border of the Polish Carpathians. Abhandlungen der Akademie der Wissenschaften in Göttingen 29: 185-196.

Kobojek E., 2009a. Naturalne uwarunkowania różnych reakcji rzek nizinnych na antropopresję na przykładzie środkowej Bzury i jej dopływów. Wydawnictwo Uniwersytetu Łódzkiego, Łódź: 1-203.

Kobojek E., 2009b. Lokalne uwarunkowania holoceńskich procesów fluwialnych w dolinach rzecznych Równiny Łowicko-Błońskiej, W: A.Kostrzewski, Re.Paluszkiewicz (red.), Geneza, litologia i stratygrafia utworów czwartorzędowych, t.V, Seria Geografia 88: 203-218.

Kobojek E., 2013. Wpływ działalności bobrów na lokalne procesy fluwialne w wybranych rzekach Równiny Łowicko-Błońskiej. Acta Universitatis Lodziensis, Folia Geographica Physica, 12: 17-32.

Kociuba D. 2003. Zmiany funkcji dolin rzecznych na obszarze Lublina. Annales Universitatis Mariae Curie-Skłodowska. Sectio B, Geographia, Geologia, Mineralogia et Petrographia 58 (5): 121-137.

Kociuba D. 2006a. Antropogeniczne zmiany sieci hydrograficznej i funkcji dolin rzecznych na obszarze Lublina w XX w. [w:] A. Latocha, A. Traczyk (red.) Zapis działalności człowieka w środowisku przyrodniczym. Metody badań i studia przypadków. IGiRR UW, SGP. Wyd. Gajt, Wrocław: 41-50.

Kociuba W., 2002. Współczesny rozwój dna doliny górnego Wieprza. MS. Archiwum UMCS, Lublin.

Kociuba W., 2006b. Changes in the Wieprz River channel pattern in Guciów as an indicator of anthropogenization and renaturalisation of valley environment. W: E.Skowronek, W.Wołoszyn, T.Speck, K.M.Born (eds), Cultural Landscapes of the Lublin Upland and Roztocze. Kartpol s.c., Lublin: 179-183.
Kociuba W., 2007. Zmiany krajobrazów dolin rzecznych w warunkach zróżnicowanej antropopresji na przykładzie roztoczańskiej doliny Wieprza. [W:] red. U. Myga-Piątek, Doliny rzeczne. Przyroda-Krajobraz-Człowiek. Prace Komisji Krajobrazu Kulturowego PTG nr 7, Sosnowiec: 342-350.

Kociuba W., 2014. Geomorphological record of transformations of upland river valley bottoms at variable rate of gully erosion (case study: Wieprz River valley in Roztocze). Annales Universitatis Mariae Curie-Skłodowska. Sectio B, Geographia, Geologia, Mineralogia et Petrographia 69(1): 93-106.

Kociuba W., Brzezińska-Wójcik T., 1999. Zarys paleogeografii roztoczańskiego odcinka doliny Wieprza (SE Polska) w czwartorzędzie. Annales Universitatis Mariae Curie-Skłodowska. Sectio B, Geographia, Geologia, Mineralogia et Petrographia 54(5): 49-82.

Kociuba W., Brzezińska-Wójcik T., 2002: Zarys paleogeografii roztoczańskiego odcinka doliny Wieprza (SE Polska) w czwartorzędzie. Annales Universitatis Mariae Curie-Skłodowska. Sectio B, Geographia, Geologia, Mineralogia et Petrographia LIV, 5 (1999): 49-82.

Kociuba W., Superson J., 2004. Ewolucja roztoczańskiego odcinka doliny Wieprza. W: R.Dobrowolski, S.Terpiłowski (red.), Stan i zmiany środowiska geograficznego wybranych regionów wschodniej Polski. Wydawnictwo Uniwersytetu Marii Curie-Skłodowskiej, Lublin: 97-104.

Kordowski J., Gamrat W., Gierszewski P., Kubiak-Wójcicka K., Szmańda J.B., Tyszkowski S., Solarczyk A., 2014. Zapis procesów sedymentacji fluwialnej i biogenicznej w osadach dna Doliny Dolnej Wisły. Landform Analysis 25: 77-93.

Korpak J. 2010. Geomorphologic effects of river engineering structures in Carpathian fluvial systems. Landform Analysis 14: 34-44.

Korpak J., Krzemień K., Radecki-Pawlik A., 2008. Wpływ czynników antropogenicznych na zmiany koryt cieków karpackich. Infrastruktura i Ekologia Terenów Wiejskich 4.

Kostrzewski A., 1970. Uziarnienie i obróbka współczesnych aluwiów bobru jako wyraz dynamiki rzecznego środowiska sedymentacyjnego. Prace Komisji Geograficzno-Geologicznej PTPN VIII(4).

Kostrzewski A., Mazurek M., Zwoliński Zb., 1994. Dynamika transportu fluwialnego górnej Parsęty jako odbicie funkcjonowania systemu zlewni. Stowarzyszenie Geomorfologów Polskich, Poznań.

Kostrzewski A., Zwoliński Zb., Andrzejewski L., Florek W., Mazurek M., Niewiarowski W., Podgórski Z., Rachlewicz G., Smolska E., Stach A., Szmańda J., Szpikowski J., 2008. Współczesna ewolucja rzeźby młodoglacjalnej Niżu Polskiego. W: Współczesne przemiany rzeźby Polski. Starkel L., Kostrzewski A., Kotarba A., Krzemień K. (red), Wydawnictwo IGiGP UJ, Kraków: 271-325.

Koutaniemi L., Rachocki A., 1981. Palaeohydrology and landscape development in the middle course of Radunia basin, North Poland. Fennia 159(2): 335-342.

Kowalski B.J., 1988. Warunki powstania i rozwój przełomowego odcinak doliny rzeki Lubrzanki przez główne pasmo Gór Świętokrzyskich w trzeciorzędzie. Przegląd Geograficzny 60(3): 329-351.

Kozarski S., 1965. Zagadnienie drogi odpływu wód pradolinnych z zachodniej części pradoliny Noteci-Warty. Prace Komisji Geograficzno-Geologicznej Poznańskiego Towarzystwa Przyjaciół Nauk 5(1).

Kozarski S., 1981. River channel changes in the Warta valley. Guide-book of excursion symposium Paleohydrology of the temperate zone, Poznań - Poland: 6-23.

Kozarski, S., 1983. River channel changes in the middle reach of the Warta valley, Great Poland Lowland. Quaternary Studies in Poland 4: 159-169.

Kozarski S., 1991. Warta - a case study of a lowland river. W: Temperate Palaeohydrology, L. Starkel, K.J. Gregory, J.B. Thornes (red.), John Wiley, Chichester: 189-215.

Kozarski S., Gonera P., Antczak B., 1988. Valley floor development and paleohydrological changes: The Late Vistulian and Holoce- 
ne history of the Warta River (Poland). In: G.Lang, Ch.Schluchter(eds), Lake, Mire and River Environment. Balkema: 185-203.

Kozarski S., Rotnicki K.. 1977. Valley floors and changes of river channel pattern in the North Polish Plain during the Late-Wurm and Holocene, Quaestiones Geographicae 4: 51-93.

Krupa J., 2013. Naturalne i antropogeniczne procesy kształtujące dno doliny Czarnej Nidy w późnym vistulianie i holocenie. Folia Quaternaria 81: 5-174.

Krygowski B., 1962. Uwagi o niektórych typach zaburzeń glacitektonicznych niżowej części Polski Zachodniej. Badania Fizjograficzne nad Polską Zachodnią 9: 61-85.

Krygowski B., 1974. O przetrwałości stref glacitektonicznych. Zeszyty Naukowe UAM. Geografia 4, Poznań.

Krzemień K., 2003. The Czarny Dunajec River, Poland, as an example of human-induced development tendencies in a mountain river channel. Landform Analysis 4: 57-64.

Krzemień K. (red.), 2012. Struktura koryt rzek i potoków (studium metodyczne). IGiGP UJ, Kraków: 1-144.

Krzyszkowski D., Bridgland D.R., Allen P., Westaway R. Wachecka-Kotkowska L., Czerwonka J.A., 2018. Drainage evolution in the Polish Sudeten Foreland in the context of European fluvial archives. Quaternary Research 91(2): 493-519.

Kukulak J., 2003. Impact of mediaeval agriculture on the alluvium in the San river headwaters (Polish Eastern Carpathians). W: G.Brierley, M.Stankoviansky (eds), Geomorphic Responses to Land Use Changes, Catena 51(3-4): 255-266.

Kukulak J., 2004. Zapis skutków osadnictwa i gospodarki rolnej w osadach rzeki górskiej na przykładzie aluwiów dorzecza górnego Sanu w Bieszczadach Wysokich. Akademia Pedagogiczna im. Komisji Edukacji Narodowej w Krakowie, Prace Monograficzne 381.

Kukulak J., 2015. Terasy Wetliny w Bieszczadach (Karpaty Wschodnie) - próba porównania ich hipsometrii, budowy i wieku z doliną górnego Sanu. Landform Analysis 28: 29-44.

Kundzewicz Z.W., 2012. Zmiany ryzyka powodziowego w Europie. Sympozjum Europejskie - Współczesne problemy ochrony przeciwpowodziowej, Paris - Orléans: 1-9.

Kupiec M., 2014. Przemiany krajobrazowe wybranych dolin rzecznych w Polsce północno-zachodniej od XIX do początków XXI wieku. Zachodniopomorski Uniwersytet Technologiczny, Szczecin: $1-198$.

Latocha A., 2007. Przemiany środowiska przyrodniczego w Sudetach Wschodnich w warunkach antropopresji. Wydawnictwo Uniwersytetu Wrocławskiego, Studia Geograficzne 8 1-216.

Latocha A., 2009. Land use changes and longer-term human-environment interactions in a mountain region (Sudetes Mountains, Poland). Geomorphology 108: 48-57.

Latocha A., 2013. Wyludnione wsie w Sudetach. I co dalej?. Przegląd Geograficzny 85(3): 373-396.

Liro M., 2017. Dam-induced base-level rise effects on the gravel-bed channel planform. Catena 153: 143-156.

Lechowska E., 2017. Ryzyko powodziowe w miastach nadodrzańskich w kontekście sposobu zagospodarowania obszarów zalewowych. Acta Universitatis Lodziensis, Folia Geographica Socio-Oeconomica 29: 65-92.

Ludwikowska-Kędzia M., 2000. Ewolucja środkowego odcinka doliny rzeki Belnianki w późnym glacjale i holocenie. Wydawanictwo Akademickie Dialog, Warszawa.

Łach J., 2007. Wpływ zabudowy koryt rzecznych na przekształcanie den dolinnych rzek sudeckich w czasie ekstremalnych powodzi. W: A.Kostrzewski, J.Szpikowski (red.), Procesy ekstremalne w środowisku geograficznym, Poznań: 57-67.

Łajczak A., 1995. Potential Rates of the Present-Day Overbank Sedimentation in the Vistula Valley at the Carpathian Foreland, Southern Poland. Quaestiones Geographicae 17/18: 41-53.

Łajczak A., 1999. Współczesny transport i sedymentacja materiału unoszonego w Wiśle i głównych dopływach. Monografie Komitetu Gospodarki Wodnej PAN 15: 215.

Łajczak A., 2004. Negative consequences of regulation of meandering sandy river and proposals tending to diminish flood hazard. Case study of the Nida river, Poland. Proceedings of the 9th International Symposium on River Sedimentatiom (IRTCES 2004), Yichang, China, III: 1773-1783.

Łajczak A., 2006a. Regulacja rzeki a zagrożenie powodziowe, na przykładzie Wisły między Skoczowem i Puławami. W: W.Bartnik (red.), Infrastruktura i ekologia terenów wiejskich. Komitet Techniczny Infrastruktury Wsi, PAN, Kraków, 4(1): 38-45.

Łajczak A., 2006b. Regulacja rzeki a zagrożenie powodziowe, na przykładzie Nidy. W: W.Bartnik (red.), Infrastruktura i ekologia terenów wiejskich. Komitet Techniczny Infrastruktury Wsi, PAN, Kraków, 4(1): 46-53.

Łajczak A., 2006c. Deltas in dam-retained lakes in the Carpathian part of the Vistula drainage basin. W: Chalov R., Kamykowska M., Krzemień K. (red.) Channel processes in the rivers of mountains, foothills and plains. Prace Geograficzne 116: 99-109.

Łajczak A., Margielewski W., Rączkowska Z., Świechowicz J., 2014. Contemporary geomorphic processes in the Polish Carpathians under changing human impact. Episodes 37(1): 21-32.

Łajczak A., Plit J., Soja R., Starkel L., Warowna L., 2006. Changes of the Vistula River Channel and Floodplain in the Last 200 Years. Geographia Polonica 79(2): 65-87.

Łajczak A., Plit J., Soja R., Starkel L., Warowna L., 2008. Współczesne przemiany koryta i równiny zalewowej Wisły. W: L.Starkel, A.Kotarba, A.Kostrzewski, K.Krzemień (red.), Współczesne przemiany rzeźby Polski. Wydawnictwo IGiGP UJ, Kraków: 349-369.

Magnuszewski A., 2002. Systemy geoinformacyjne w badaniach ekohydrologicznych. WGSR UW, Warszawa.

Malik I., Owczarek P., 2006. Dendrochronologiczny zapis erozji i depozycji w potokach górskich przegrodzonych zaporami przeciwrumowiskowymi na przykładzie Cernego Potoku (Jeseniki Sudety Wschodnie). Przegląd Geograficzny 79: 313-334.

Mazurek M., 1998. Dostawa materiału klastycznego do transportu fluwialnego na obszarach młodoglacjalnych (zlewnia Kłudy, Pomorze Zachodnie). Badania Fizjograficzne nad Polską Zachodnią 49: 127-146.

Mazurek M., 2006. Morphometric differences in channel heads in a postglacial zone (Parsęta catchment, West Pomerania). Quaestiones Geographicae 25(A): 39-47.

Mazurek M., 2010. Hydrogeomorfologia obszarów źródliskowych (dorzecze Parsęty, Polska NW). Wydawnictwo Naukowe UAM, Seria Geografia 92: 1-304.

Mazurek M., Paluszkiewicz R., 2013. Formation and development of a 1st-order valley network in postglacial areas (the Dębnica catchment). Landform Analysis 22: 75-87.

Michno A., 2013. Rozwój dolin w ujściowych odcinkach rzek na wyżynach lessowych w Polsce. Uniwersytet Jagielloński, Instytut Geografii i Gospodarki Przestrzennej, Kraków.

Migoń P., 2008. Współczesna ewolucja rzeźby Sudetów i ich Przedgórza. W: L.Starkel, A.Kostrzewski, A.Kotarba, K.Krzemień (red.), Współczesne przemiany rzeźby Polski, Wydawnictwo IGiGP UJ, Kraków: 135-163.

Młynarczyk Z, Rotnicki K., 1989. Foold and vortex cour of the channel bed of the Prosna River and their depth range. Earth Surface Processes and Landforms 14: 365-373.

Mojski J.E., Starkel L., 1990. The physical setting, geological structure and morphology. W: L.Starkel (red.), Evolution of the Vistula river valley during the last 15000 years, part III, Geographical Studies, Special Issue 5: 34-41.

Niedźwiedź T., Starkel L., 2008. Klimatyczne tło współczesnych procesów morfogenetycznych na obszarze Polski. W: L.Starkel, A.Kostrzewski, A.Kotarba, K.Krzemień (red.), Współczesne przemiany rzeźby Polski, Wydawnictwo IGiGP UJ, Kraków: 21-33.

Niewiarowski W., 1968. Morfologia i rozwój pradoliny i doliny dolnej Drwęcy. Studia Societatis Scientiarum Torunensis, ser. C 6(6): 1-132.

Niewiarowski W., 1986. The phases of transformation of subglacial channel into River Valley: a case study of the Lower Vistula Region. Acta Universitatis Nicolai Copernici, Geografia 21: 61-72.

Niewiarowski W., 1987. Evolution of the lower Vistula valley in the Unislaw Basin and at the river gap to the north of Byd- 
goszcz-Fordon. W: L.Starkel (red), Evolution of the Lower Vistula River valley during the last 15000 years, Part II. Geographical studies, Special Issue 4: 233-252.

Nowaczyk B., 1994. Wiek jezior i problemy zaniku brył pogrzebanego lodu na przykładzie sandru Brdy w okolicy Charzykowy Acta Universitatis Nicolai Copernici, Geografia 27: 97-110.

Nowicka B., 2009. Ocena zróżnicowania ekstremalnie wysokich przepływów wybranych rzek polskich. Prace i Studia Geograficzne 43: 11-24.

Ostrowski P., Falkowski T., 2016. Zastosowanie wysokorozdzielczych, wielospektralnych zdjęć satelitarnych (VHR) do identyfikacji wybranych form rzeźby równi zalewowej. Przegląd Geologiczny 64(12): 1040-1047.

Ostrowski P., Kaszyński K., 2014. Ocena tendencji współczesnej ewolucji wybranego fragmentu koryta dolnego Bugu na podstawie materiałów kartograficznych i teledetekcyjnych. Landform Analysis 26: 11-20.

Pałys S., 1971. Erozja górnego i środkowego odcinka rzeki Wieprz na tle ogólnej charakterystyki zlewni. Zeszyty Problemowe Postępów Nauk Rolniczych 16(119): 67-89.

Pawlaczyk P., 2017. Ekologiczne problemy ochrony rzek w polskich obszarach Natura 2000. Przegląd Przyrodniczy XXVIII(4): 16-50.

Pawlik Ł., 2010. Mapa zagrożeń geomorfologicznych wywołanych wezbraniem rzeki górskiej (na przykładzie dolnej części doliny Ścinawki, Sudety Środkowe). Przegląd Geograficzny 82(3): 367-387.

Petera J., 2002. Vistuliańskie osady dolinne w basenie uniejowskim i ich wymowa paleogeograficzna. Acta Geographica Lodziensia 83: 1-164.

Petera J., Forysiak J., 2003. The problem of the Last Glaciation extent in Central Poland. Geological Quarterly 47(4): 357-366.

Petera-Zganiacz J., 2008. Wiek i sposób wykształcenia struktur peryglacjalnych w dolinie dużej rzeki na przykładzie stanowiska Koźmin w dolinie Warty. Landform Analysis 9: 167-170.

Piasecki D., 1982. Ewolucja dolin rzek Przymorza. Przegląd Geograficzny 54(1-2): 49-68.

Plit J., Warowna J., 2008. Zmiany układu i kształtu koryt w ciągu ostatnich 250 lat - procesy w uregulowanym korycie Wisły. W: L.Starkel, A.Kostrzewski, A.Kotarba, K.Krzemień (red.), Współczesne przemiany rzeźby Polski, Wydawnictwo IGiGP UJ, Kraków: 356-361.

Podgórski Z., 2004. Wpływ budowy i funkcjonowania młynów wodnych na rzeźbę terenu i wody powierzchniowe Pojezierza Chełmińskiego i przyległych części dolin Wisły i Drwęcy. Wydawnictwo UMK, Toruń.

Podgórski Z., 2009. Młyny wodne w krajobrazie Pojezierza Chełmińskiego. Prace i Studia Geograficzne 41: 151-161.

Rachocki A., 1974. Przebieg i natężenie współczesnych procesów rzecznych w korycie Raduni. Dokumentacja Geograficzna 4.

Radecki-Pawlik A., 2014. Hydromorfologia rzek i potoków górskich. Działy wybrane. Wydawnictwo Uniwersytetu Rolniczego w Krakowie.

Rodzik J., Ciupa T., Janicki G., Kociuba W., Tyc A., Zgłobicki W., 2008. Współczesne przemiany rzeźby Wyżyn Polskich. W: L.Starkel, A.Kostrzewski, A.Kotarba, K.Krzemień (red.), Współczesne przemiany rzeźby Polski, Wydawnictwo IGiGP UJ, Kraków: 165-228.

Rotnicki K., 1983. Modeling past discharges of meandering rivers. W: K.J. Gregory (ed.), Background to Palaeohydrology, John Wiley, Chichester: 321-354.

Rotnicki K., 1987. Main phases of erosion and accumulation in the Prosna valley in the last glacial-interglacial cycle. Geographia Polonica 53: 54-65.

Rotnicki K., Młynarczyk Z., 1989. Późnovistulianskie i holoceńskie formy i osady korytowe w dolinie środkowej Prosny i ich paleohydrologiczna interpretacja. Seria Geografia 43, Wydawnictwo Naukowe UAM, Poznań.

Rurek M., Krupa A., Hojan M., Giętkowski T., 2013. Wpływ działalności bobrów na rzeźbę małych dolin na przykładzie doliny
Gajdówki, południowe Bory Tucholskie, Polska. Journal of Health Sciences 3(15): 257-266.

Rurek M., Śnieszko Z., Makohonienko M., 2016. Współczesne i kopalne stawy bobrowe w małych dolinach rzecznych na obszarze Borów Tucholskich. Uniwersytet Kazimierza Wielkiego, Bydgoszcz.

Schumm S.A., 1977. The fluvial system. John Wiley and Sons, New York.

Skolasińska K., Szczuciński W., Mitręga M., Jagodziński R., Lorenc S., 2015. Sedimentary records of 2010 and 2011 Warta River seasonal floods in the region of Poznań, Poland. Geological Quarterly 59(1): 47-60.

Słowik M., 2017. The formation of an anabranching planform in a sandy floodplain by increased flows and sediment load. Earth Surface Processes and Landforms 43(3): 623-638.

Smolska E., 1996. Funkcjonowanie systemu korytowego w obszarze młodoglacjalnym na przykładzie górnej Szeszupy (Pojezierze Suwalskie). WGiSR UW, Warszawa: 1-123.

Sołtysik R., 2002. Geneza mokradeł Gór Świętokrzyskich i Niecki Nidziańskiej. Prace Instytutu Geografii Akademii Świętokrzyskiej 9: 1-122.

Starkel L. (red.), 1982-1996. Evolution of the Vistula river valley during the last 15000 years, part I-VI. Geographical Studies, Special Issue 1, 4, 5, 6, 8, 9.

Starkel L., 1981. Stan badań nad historią doliny Wisły w późnym glacjale i holocenie. Przegląd Geograficzny 53(1): 3-16.

Starkel L., 1983. The reflection of hydrologic changes in the fluvial environment of the temperate zone Turing the last 15000 years. W: K.J. Gregory (ed.), Background to Palaeohydrology, John Wiley, Chichester: 213-235.

Starkel L., 1988. Historia dolin rzecznych w holocenie. W: L.Strakel (red.), Przemiany środowiska geograficznego Polski, Ossolineum, Wrocław: 87-107.

Starkel L., 1991a. Long-distance correlation of fluvial events in the temperate zone. W: L.Starkel, K.J.Gregory, J.B.Thornes (eds), Temperate paleohydrology, John Wiley and Sons, Chichester: 473-495.

Starkel L., 1991b. The Vistula river valley: a case study for Central Europe. W: L.Starkel, K.J.Gregory, J.B.Thornes (eds), Temperate paleohydrology, John Wiley and Sons, Chichester: 171-188.

Starkel L., 1995. Palaeohydrology of the temperate zone. W: K.J.Gregory, L.Starkel, V.R.Baker (eds), Global Continental Palaeohydrology, John Wiley and Sons, Chichester: 233-257.

Starkel L., 1997. The evolution of fluvial systems in the Upper Vistulian and Holocene in the territory of Poland. Landform Analysis 1: 7-18.

Starkel L., 2001. Historia doliny Wisły od ostatniego zlodowacenia do dziś. Monografie IGPZ PAN, 2.

Starkel L., 2002. Change in the frequency of extreme events as the indicator of climatic change in the Holocene (in fluvial systems). Quaternary International 91: 25-32.

Starkel L., 2003. Palaeohydrology of Central Europe. W: K.J.Gregory, G.Benito (eds), Palaeohydrology: Understending Global Change, John Wiley and Sons, Chichester: 77-104.

Starkel L., 2005. Współczesna rzeźba Polski dziedziczy cechy peryglacjalne. Przegląd Geograficzny 77: 5-13.

Starkel L., 2007. The diversity of fluvial system response to the Holocene hydrological changes using the Vistula River catchment as an example. Annales Societatis Geologorum Poloniae 77: 193-205.

Starkel L., 2008. Paleogeograficzne korzenie współczesnej rzeźby Polski. W: L.Starkel, A.Kostrzewski, A.Kotarba, K.Krzemień (red.), Współczesne przemiany rzeźby Polski, Wydawnictwo IGiGP UJ, Kraków: 13-20.

Starkel L., 2014. O niektórych prawidłowościach rozwoju rzeźby gór i ich przedpoli (na przykładzie wybranych gór Eurazji). Wydawnictwo Akademickie SEDNO, Instytut Geografii i Przestrzennego Zagospodarowania PAN, Warszawa.

Starkel L., 2017. Uwagi o poligenezie rzeźby gór (na przykładzie Karpat). Acta Geographica Lodziensia 106: 31-35. 
Starkel L., Gębica P., Superson J., 2007. Last Glacial - Interglacial cycle in the evolution of river valleys in southern and central Poland. Quaternary Science Reviews 26(22): 2924-2936.

Starkel L., Kalicki T., Krąpiec M., Soja R., Gębica P., Czyżowska E., 1996. Hydrological changes of Valley floors in upper Vistula basin during the last 15000 years. W: L.Starkel (red.), Evolution of the Vistula river valley during the last 15000 years, part VI, Geographical Studies, Special Issue 9: 7-128.

Starkel L., Kostrzewski A., Kotarba A., Krzemień K. (red.), 2008. Współczesne przemiany rzeźby Polski. Wydawnictwo IGiGP UJ, Kraków.

Starkel L., Łajczak A., 2008. Kształtowanie rzeźby den dolin w Karpatach (koryt i równin zalewowych). W: L.Starkel, A.Kostrzewski, A.Kotarba, K.Krzemień (red.), Współczesne przemiany rzeźby Polski, Wydawnictwo IGiGP UJ, Kraków: 95-108.

Stopka R., 2011. Geomorfologiczne skutki działalności bobra europejskiego Castor fiber w dolinie górnego Sanu. Roczniki Bieszczadzkie 19: 319-334.

Sylwestrzak J., 1978. Rozwój sieci dolinnej na Pomorzu pod koniec plejstocenu. Gdańskie Towarzystwo Naukowe, Zakład Narodowy im. Ossolińskich.

Szafarniec J., 2010. Próba oszacowania maksymalnych przepływów wód lodowcowych lądolodu Wisły na Pomorzu. Landform Analysis 13: 107-115.

Szmańda J.B., 2011. Zapis warunków depozycji w uziarnieniu aluwiów pozakorytowych. Landform Analysis 18.

Szpikowski J., Szpikowska G., 2018. Akumulacja osadów w rozlewiskach bobrowych w świetle oceny wielkości denudacji mechanicznej zlewni młodoglacjalnej (Kłuda, Pomorze Zachodnie). W: A.Kostrzewski, A.Stach, M.Majewski (red.), Geneza, litologia i stratygrafia utworów czwartorzędowych, t. VII, Instytut Geoekologii i Geoinformacji UAM: 197-204.

Szumański A., 1972. The valley of lower San river in the Sandomierz Basin. Excursion Guide-Book of Holocene Symposium 2: $55-68$.

Szumański A., 1986. Postglacjalna ewolucja i mechanizm transformacji dna doliny dolnego Sanu. Kwartalnik AGH, Geologia 12(1): 1-92.

Teisseyre A.K., 1977. Współczesne procesy rzeczne w dorzeczu górnego Bobru I Strzegomki (Sudety Środkowe). Geologica Sudetica 1292): 93-109.

Teisseyre A.K., 1979. Przebieg zjawisk fluwialnych w zimie na przykładzie małych rzek sudeckich. Geologica Sudetica 14(1): $125-158$.

Teisseyre A.K., 1985. Mady dolin sudeckich. Cz. I. Ogólna charakterystyka środowiska (na przykładzie zlewni górnego Bobru). Geologica Sudetica 20(1): 113-195.

Tofelde S., Savi S., Wickert A.D., Bufe A., Schildgen T.F., 2019. Alluvial channel response to environmental perturbations: fillterrace formation and sediment-signal disruption. Earth Surface Dynamics 7: 609-631.

Tomczak A., 1987. The evolution of the Vistrula Valley in the Toruń Basin in the Late Glacial and Holocene. W: L.Starkel (red.), Evolution of the Vistula river valley during the last 15000 years, part II, Geographical Studies, Special Issue 4: 207-231.

Trafas K., 1992. Zmiany biegu Wisły pomiędzy ujściem Przemszy a Sandomierzem W: Zmiany biegu górnej Wisły i ich skutki. Wydawnictwo Uniwersytetu Warszawskiego, Warszawa: 3142.

Turkowska K., 1975. Rzeczne procesy peryglacjalne na tle morfogenezy doliny Mrogi. Acta Geographica Lodziensia 36: 1-122.

Turkowska K., 1988. Rozwój dolin rzecznych na Wyżynie Łódzkiej w czwartorzędzie. Acta Geographica Lodziensia 57: 1-157.

Turkowska K., 2006. Geomorfologia regionu łódzkiego. Wydawnictwo Uniwersytetu Łódzkiego, Łódź.

Twardy J., 2000. Deluwia neoholoceńskie - przykłady z Wyżyny Łódzkiej. Acta Geographica Lodziensia 78: 135-173.

Twardy J., 2008. Fazy transformacji rzeźby środkowej Polski w warunkach antropopresji w świetle badań geosystemów eolicznych, stokowych i rzecznych. Landform Analysis 9: 324-328.
Twardy J., 2013. Pradziejowa kolonizacja małych dolin rzecznych środkowej Polski i jej konsekwencje dla rozwoju rzeźby. Landform Analysis 24: 97-106.

Twardy J., Klimek K., 2008. Współczesna ewolucja strefy staroglacjalnej Niżu Polskiego. W: L.Starkel, A.Kostrzewski, A.Kotarba, K.Krzemień (red.), Współczesne przemiany rzeźby Polski, Wydawnictwo IGiGP UJ, Kraków: 229-269.

Vandenberghe J., 1995. Postglacial river activity and climate: state-of-the-art and future prospects. W: B.Frenzel, J.Vandenberghe, C.Kasse, S.Bohncke, B.Gläser (eds), European river activity and climatic change during the Lateglacial and early Holocene. Paläoklimaforschung 14: 1-9.

Warachowska W., Zwoliński Zb., Matczak P., w druku. Gospodarka polderowa $\mathrm{w}$ Polsce.

Weckwerth P., 2014. Transformacja form korytowych na przykładzie aluwiów piaskodennych rzek roztokowych środkowego vistulianu w Kotlinie Toruńskiej. Landform Analysis 25: 169-177.

Wierzbicki G., Ostrowski P., Falkowski T, Mazgajski M., 2018. Geological setting control of flood dynamics in lowland rivers (Poland). Science of the Total Environment 636: 367-382.

Wierzbicki, M., Hammerling, M., Przedwojski,B., 2008. Przebieg procesu erozji poniżej zbiornika Jeziorsko na rzece Warcie. Przegląd Naukowy Inżynieria i Kształtowanie Środowiska 17(2/40): $136-145$.

Wiśniewski E., 1976. Rozwój geomorfologiczny doliny Wisły pomiedzy Kotlina Płocką a Kotliną Toruńską. Prace Geograficzne IGiPZ PAN, 119.

Wiśniewski E., 1987. The evolution of the Vistula river valley between Warsaw and Plock Basin during the last 15000 years. W: L.Starkel (red.), Evolution of the Vistula river valley during the last 15000 years, part II, Geographical Studies, Special Issue 4: 171-187.

Witek M., 2012. Wpływ zabudowy hydrotechnicznej na współczesne kształtowanie rzeźby koryt rzek ziemi kłodzkiej. Landform Analysis 19: 91-102.

Witek M., Białobrzeska M., 2012. Oddziaływanie obiektów hydrotechnicznych na morfologię koryt rzek ziemi kłodzkiej w świetle analizy GIS - zarys problemu i zamierzenia badawcze. Landform Analysis 20: 103-116.

Witkowski K., Witkowski M., 2017. Wpływ młynów wodnych na przekształcenia sieci hydrograficznej Wadowic i okolic. Wadoviana, Przegląd historyczno-kulturalny 20: 100-113.

Witkowski K., Wysmołek G., 2015. Wpływ regulacji Skawy na rozwój form korytowych. Landform Analysis 30: 21-27.

Wolski J., 2007. Przekształcenia krajobrazu wiejskiego Bieszczadów Wysokich w ciągu ostatnich 150 lat. Prace Geograficzne IGiPZ PAN 214.

Wrońska-Wałach D., 2012. Przeglądowe i szczegółowe podejścia do badań struktury koryt rzecznych w literaturze geomorfologicznej. W: K.Krzemień (red), Struktura koryt rzek i potoków (studium metodyczne). IGiGP UJ, Kraków: 121-130.

Wyżga B., 1993. Funkcjonowanie systemu rzecznego środkowej i dolnej Raby w ostatnich 200 latach. Dokumentacja Geograficzna 6 .

Wyżga B., 2008. Wcinanie się rzek polskich Karpat w ciągu XX wieku. W: B.Wyżga (red.), Stan środowiska rzek południowej Polski i możliwości jego poprawy - wybrane aspekty, Instytut Ochrony Przyrody PAN, Kraków: 7-39.

Wyżga B., Hajdukiewicz H., Radecki-Pawlik A., Zawiejska J., 2010. Eksploatacja osadów z koryt rzek górskich - skutki środowiskowe i procedury oceny. Gospodarka Wodna 6: 243-249.

Wyżga B., Radecki-Pawlik A., Zawiejska J., 2008. Dlaczego konieczna jest rewitalizacja rzek karpackich? Prace Komisji Krajobrazu Kulturowego 10: 275-282.

Zawiejska J., Wyżga B., 2010. Twentieth-century channel change on the Dunajec River, southern Poland: patterns, causes and controls. Geomorphology, 117: 234-246.

Zawiejska J., Wyżga B., Radecki-Pawlik A., 2015. Variation in surface bed material along a mountain river modified by gravel extraction and channelization, the Czarny Dunajec, Polish Carpathians. Geomorphology, 23: 353-366. 
Żelazo J., 2006. Renaturyzacja rzek i dolin. Infrastruktura i Ekologia Terenów Wiejskich 4(1): 11-31.

Żelazo J., Popek Z., 2002. Podstawy renaturyzacji rzek. Wydawnictwo SGGW, Warszawa.

Zieliński T., 1998. Litofacjalna identyfikacja osadów rzecznych. W: E.Mycielska-Dowgiałło (red.), Struktury sedymentacyjne i postsedymentacyjne w osadach czwartorzędowych i ich wartości interpretacyjna, Wydział Geografii i Studiów Regionalnych UW, Warszawa: 195-257.

Zieliński T., 2003. Catastrophic flood effects in alpine/foothill fluvial system (a case study from the Sudetes Mts, SW Poland). Geomorphology 54: 293-306.

Zieliński T., 2014. Sedymentologia osady rzek i jezior. Wydawnictwo Naukowe UAM, Poznań.

Zwoliński Zb., 1985. Sedymentacja osadów przyrostu pionowego na terasie zalewowej Parsęty. Badania Fizjograficzne nad Polską Zachodnią 35: 205-238.

Zwoliński Zb., 1986. Kooperacja przepływowa jako miernik zmian reżimu rzecznego. W: A.Kaniecki (red.), Ogólnopolska Konferencja Hydrograficzna „Hydrologia regionalna i procesy hydrologiczne w zlewniach", Poznań: 221-225.

Zwoliński Zb., 1989. Geomorficzne dostosowywanie się koryta Parsęty do aktualnego reżimu rzecznego. Dokumentacja Geograficzna 3/4: 1-144.

Zwoliński Zb., 1992. Sedimentology and geomorphology of overbank flows on meandering river floodplains. W: R.Brakenridge, J.Hagedorn (eds.), Floodplain Evolution, Geomorphology, Special Issue 4(6): 367-379.

Zwoliński Zb., 1998. Geoindykatory w badaniach współczesnej dynamiki geosystemów. W: K.Pękala (red.), Główne kierunki badań geomorfologicznych w Polsce. Stan aktualny i perspektywy. I. Referaty i komunikaty, Lublin: 223-227.

Zwoliński Zb., 2007. Mobilność materii mineralnej na obszarach paraglacjalnych, Wyspa Króla Jerzego, Antarktyka Zachodnia. Wydawnictwo Naukowe UAM, Ser. Geografia 74: 1-266.

Zwoliński Zb., 2008. Wybrane zjawiska ekstremalne pojezierzy polskich. Landform Analysis 8: 98-106.

Zwoliński Zb., 2011a. Potencjalne wystąpienie zjawisk ekstremalnych w Uzdrowisku Kołobrzeg. W: A.Kostrzewski, J.Szpikowski, R.Woźniak (red.), Wpływ zmian klimatu i narastającej antropopresji na rozwój Uzdrowiska Kołobrzeg. Regionalne Stowarzyszenie Turystyczno-Uzdrowiskowe w Kołobrzegu: 65-75.

Zwoliński Zb., 2011b. Globalne zmiany klimatu i ich implikacje dla rzeźby Polski. Landform Analysis 15: 5-15.

Zwoliński Zb., 2016. Solute and solid cascade system in the Antarctic oases. W: A.A.Beylich, J.C.Dixon, Zb.Zwoliński, Source-to-Sink Fluxes in Undisturbed Cold Environments. Cambridge University Press: 183-198.

Zwoliński Zb., Hildebrandt-Radke I., Mazurek M., Makohonienko M., 2018. Anthropogeomorphological Metamorphosis of an Urban Area in the Postglacial Landscape: A Case Study of Poznań City. W: Urban Geomorphology: Landforms and Processes in Cities, M.J. Thornbush, C.D. Allen (eds.), Elsevier, Chapter 4: 55-77.

Zwoliński Zb., Kostrzewski A., Stach A., 2008. Tło geograficzne współczesnej ewolucji rzeźby młodoglacjalnej. W: L.Starkel, A.Kostrzewski, A.Kotarba, K.Krzemień (red.), Współczesne przemiany rzeźby Polski, Wydawnictwo IGiGP UJ, Kraków: 271-276.

Żurek S., 1975. Geneza zabagnienia Pradoliny Biebrzy. Prace Geograficzne IGiPZ PAN 110

Żurek S., Pazdur A., 1999. Zapis zmian paleohydrologicznych w rozwoju torfowisk Polski. W: A.Pazdur, A.Bluszcz, W.Stankowski, L.Starkel, (red.), Geochronologia górnego czwartorzędu Polski w świetle datowania radiowęglowego i luminescencyjnego, Instytut Fizyki Politechniki Śląskiej: 215-228.

\section{Aneks}

Dla porządku warto także przytoczyć dwie klasyfikacje, tym razem nie do końca oparte o kryteria geo- morfologiczne, ale po części przydatne w ocenie geomorfologicznej typologii rzek, a mianowicie za Hobot $\mathrm{i}$ in. (2014) ${ }^{1}$, która to klasyfikacja oparta jest o Ramową Dyrektywę Wodną (RDW 2000) ${ }^{2}$ oraz za Prusem $\mathrm{i}$ in. $(2017)^{3}$, których klasyfikacja generalizuje klasyfikację Hobot i in. (2014) z punktu widzenia utrzymania rzek. Pierwsza $z$ wymienionych klasyfikacji (Hobot i in. 2014) oparta jest na czterech kryteriach: 1. przynależności do ekoregionów: Niż Polski, Niziny Wschodniobałtycko-Białoruskie, Sudety, Wyżyny Polskie (łącznie z Podkarpaciem, Pogórzem karpackim i Pogórzem Sudeckim), Karpaty;

2. wysokości bezwzględnych położenia rzeki (m n.p.m.): cieki górskie $(>800 \mathrm{~m})$, cieki wyżynne $(200-800 \mathrm{~m})$, cieki nizinne $(<200 \mathrm{~m})$;

3. wielkości obszaru zlewni: mała $\left(10-100 \mathrm{~km}^{2}\right)$, średnia (100-1000 km²), duża (1000-10 000 $\left.\mathrm{km}^{2}\right)$, bardzo duża $\left(>10000 \mathrm{~km}^{2}\right)$;

4. dominującej budowie geologicznej zlewni: wapiennej, krzemianowej i organicznej (głównie torfy).

Ponadto wykorzystano do opisu poszczególnych typów rzek: średni spadek koryta, forma i kształt koryta głównego rzeki, kształt doliny i średni skład podłoża. Są to następujące typy abiotyczne rzek:

1. Krajobraz górski: 1 Potok tatrzański krzemianowy, 2 Potok tatrzański węglanowy, 3 Potok sudec$\mathrm{ki}$,

2. Krajobraz wyżynny: 4 Potok wyżynny krzemianowy $z$ substratem gruboziarnistym - zachodni, 5 Potok wyżynny krzemianowy z substratem drobnoziarnistym - zachodni, 6 Potok wyżynny węglanowy $z$ substratem drobnoziarnistym, 7 Potok wyżynny węglanowy $z$ substratem gruboziarnistym, 8 Mała rzeka wyżynna krzemianowa - zachodnia, 9 Mała rzeka wyżynna węglanowa, 10 Średnia rzeka wyżynna - zachodnia, 11 Potok wyżynny krzemianowe $\mathrm{z}$ substratem gruboziarnistym - wschodni, 12 Potok fliszowy, 13 Mała rzeka wyżynna krzemianowa - wschodnia, 14 Mała rzeka fliszowa, 15 Średnia rzeka wyżynna wschodnia,

3. Krajobraz nizinny: 16 Potok nizinny lessowo-gliniasty, 17 Potok nizinny piaszczysty, 18 Potok

\footnotetext{
1 Hobot A., Banaszak K., Borzyszkowski J., Ciupak E., Dołęga M., Hubert K., Kolada A., Kołbut Ł., Kołodziejczyk A., Komosa M., Kraśniewski W., Krzymiński W., Kunert M., Kutyła S., Mutryn J., Pasak D., Pasztaleniec A., Skuza M.K., Soszka H., Stachura-Węgierek A., Wałęga A., 2014. Etap I: „Weryfikacja typologii wód oraz granic jednolitych części wód powierzchniowych". Metodyka. Krajowy Zarzą Gospodarki Wodnej, Gliwice, Warszawa.

2 RDW [Ramowa Dyrektywa Wodna], 2000. Dyrektywa 2000/60/ WE Parlamentu Europejskiego i Rady z dnia 23 października 2000 r. ustanawiająca ramy wspólnotowego działania w dziedzinie polityki wodnej. Online: https://eur-lex.europa.eu/legal-content/PL/TXT/?uri=CELEX:02000L0060-20141120 (accessed 24 December 2018).

3 Prus P., Popek Z., Pawlaczyk P., 2017. Dobre praktyki utrzyma-
} nia rzek. WWF Polska, Warszawa. 
nizinny żwirowy, 19 Rzeka nizinna piaszczysto-gliniasta, 20 Rzeka nizinna żwirowa, 21 Wielka rzeka nizinna, 22 Rzeka przyujściowa pod wpływem wód słonych,

4. Niezależne od ekoregionów (niemieszczące się w przyjętej regionalizacji): 23 Potok lub strumień na obszarze będącym pod wpływem procesów torfotwórczych, 24 Mała i średnia rzeka na obszarze będącym pod wpływem procesów torfotwórczych, 25 Ciek łączący jeziora, 26 Ciek w dolinie wielkiej rzeki.

Ponadto klasyfikacja ta przewiduje także niekreślony typ rzeki z kodem 0 .

Prus i in. (2017) z kolei podjęli się zgeneralizowania/uproszczenia tej klasyfikacji ze względu na zbliżoną wrażliwość rzek na prace utrzymaniowe. Są to następujące grupy typów abiotycznych rzek:

1. Potoki górskie i wyżynne $z$ substratem gruboziarnistym (typy abiotyczne $\mathrm{nr}: 1,2,3,4,7$ ),

2. Potoki wyżynne $z$ substratem drobnoziarnistym (typy abiotyczne nr: 5, 6),

3. Rzeki wyżynne (typy: abiotyczne nr: 8, 9, 10, 15),
4. Potoki i rzeki fliszowe (typy: abiotyczne nr: 12, 14),

5. Potoki nizinne $z$ substratem gruboziarnistym (typ abiotyczny nr 18),

6. Potoki nizinne $z$ substratem drobnoziarnistym (typy abiotyczne nr: 16, 17),

7. Rzeki nizinne $\mathrm{z}$ substratem gruboziarnistym (typy abiotyczne: 20, 25),

8. Rzeki nizinne $z$ substratem drobnoziarnistym (typy abiotyczne nr: 19, 26),

9. Rzeki torfowe, międzyjeziorne i przyujściowe (typy abiotyczne nr: 22, 23, 24, 25),

10. Wielkie rzeki nizinne (typ abiotyczny nr 21).

Warto jeszcze raz podkreślić, że przedstawione klasyfikacje, choć wynikające po części z prawa europejskiego i krajowego, są jednak niefortunne $z$ geomorfologicznego punktu widzenia, a nawet fizjograficznego punktu widzenia i mało przydatne dla klasyfikacji typów dolin i koryt rzecznych. Niemniej należy je mieć również na uwadze przy rozważaniach typologicznych polskich rzek. 